Prepared in cooperation with the U.S. Army Corps of Engineers

\title{
Development of CE-QUAL-W2 Models for the Middle Fork Willamette and South Santiam Rivers, Oregon
}

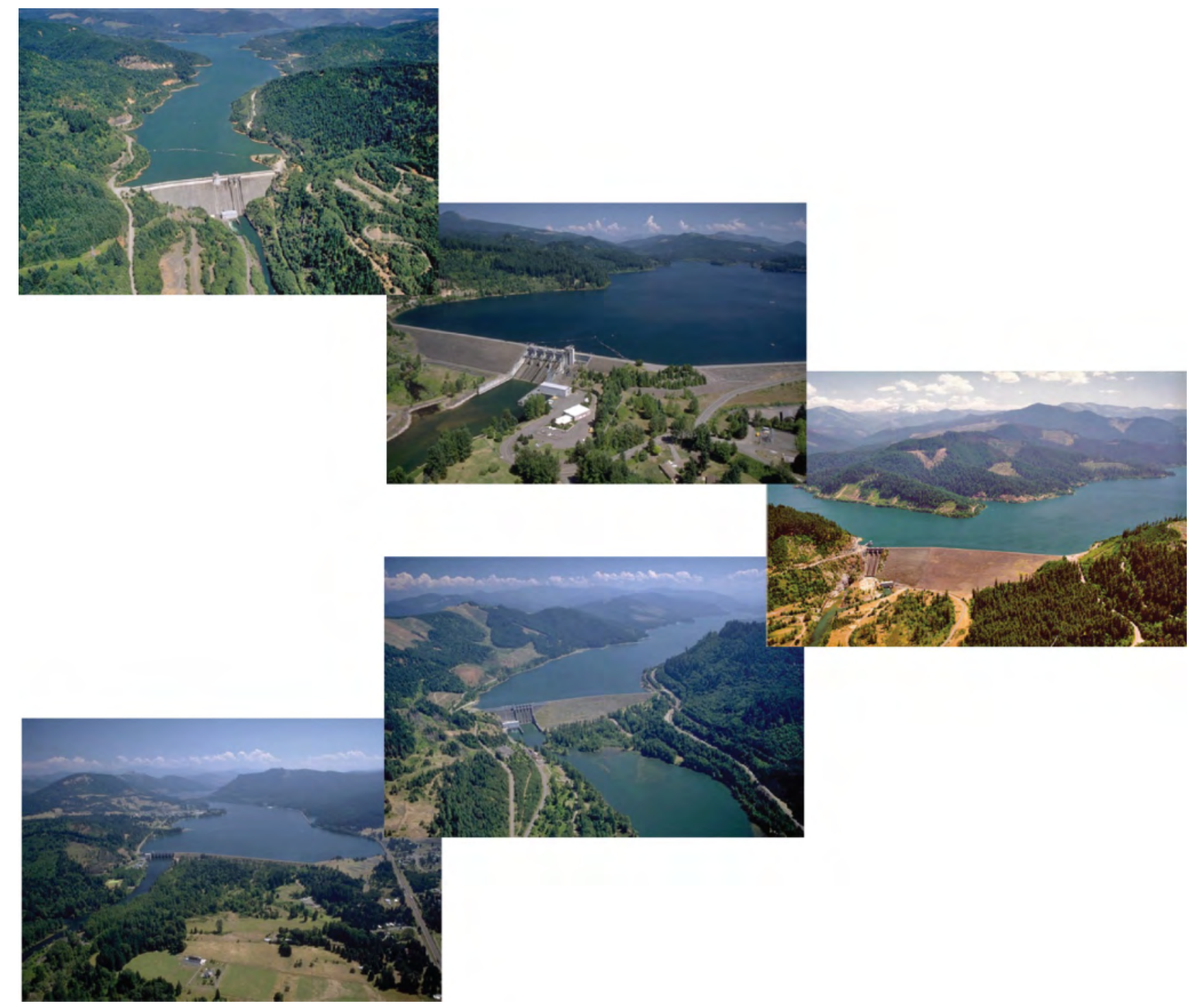

Open-File Report 2013-1186

U.S. Department of the Interior

U.S. Geological Survey 
Cover: U.S. Army Corps of Engineers operated dams in the Middle Fork Willamette and South Santiam River Basins. From top: (1) Green Peter, (2) Foster, (3) Hills Creek, (4) Lookout Point, (5) Dexter. Photos courtesy of the U.S. Army Corps of Engineers. 


\section{Development of CE-QUAL-W2 Models for the Middle Fork Willamette and South Santiam Rivers, Oregon}

By Norman L. Buccola, Adam J. Stonewall, Annett B. Sullivan, Yoonhee Kim, and Stewart A. Rounds

Prepared in cooperation with the U.S. Army Corps of Engineers Portland District

Open File Report 2013-1186

U.S. Department of the Interior

U.S. Geological Survey 


\section{U.S. Department of the Interior \\ SALLY JEWELL, Secretary}

\section{U.S. Geological Survey \\ Suzette M. Kimball, Acting Director}

U.S. Geological Survey, Reston, Virginia: 2014

For more information on the USGS-the Federal source for science about the Earth, its natural and living resources, natural hazards, and the environment:

World Wide Web: http://www.usgs.gov

Telephone: 1-888-ASK-USGS

For an overview of USGS information products, including maps, imagery, and publications, visit http://www.usgs.gov/pubprod

To order this and other USGS information products, visit http://store.usgs.gov

Any use of trade, product, or firm names is for descriptive purposes only and does not imply endorsement by the U.S. Government.

Although this report is in the public domain, permission must be secured from the individual copyright owners to reproduce any copyrighted material contained within this report.

Suggested citation:

Buccola, N.L., Stonewall, A.J., Sullivan, A.B., Kim, Yoonhee, and Rounds, S.A., 2013, Development of CE-QUAL-W2 models for the Middle Fork Willamette and South Santiam Rivers, Oregon: U.S. Geological Survey Open-File Report 2013-1186, 55 p. http://dx.doi.org/10.3133/ofr20131186

ISSN 2331-1258 (online) 


\section{Contents}

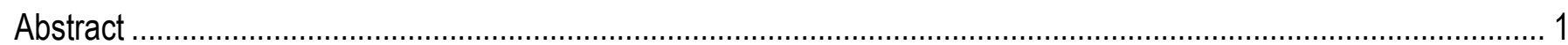

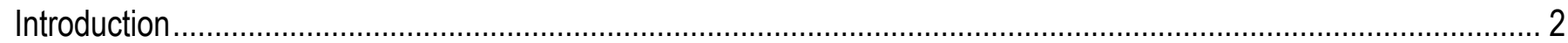

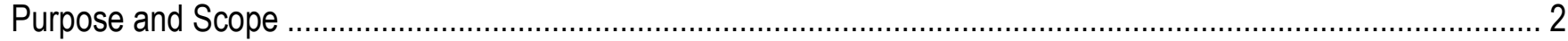

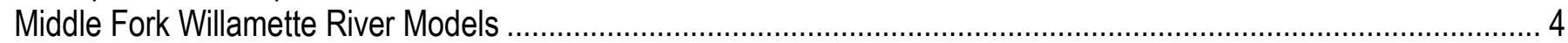

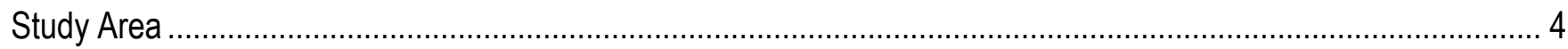

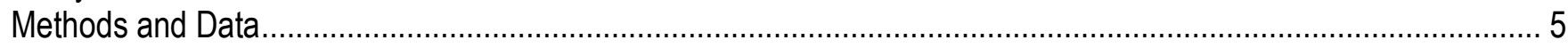

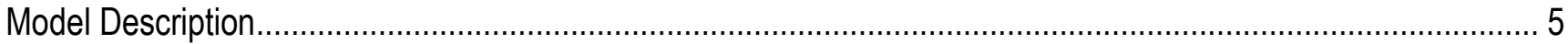

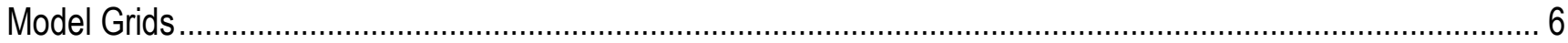

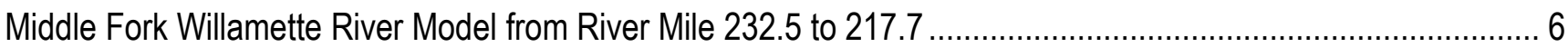

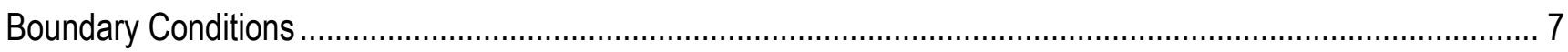

Selection of Time Periods ...........................................................................................................

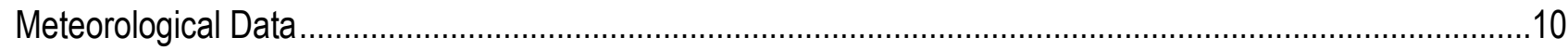

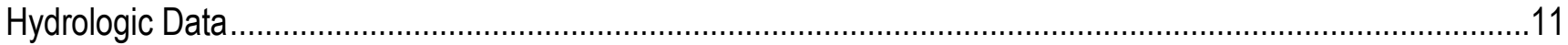

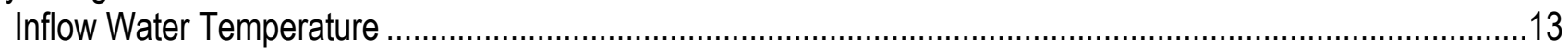

Lake Profile Data and Outflow Water Temperature................................................................................14

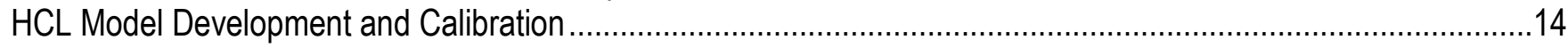

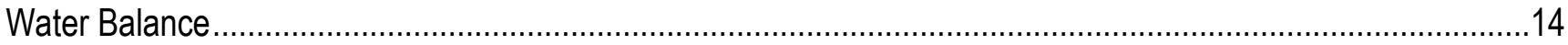

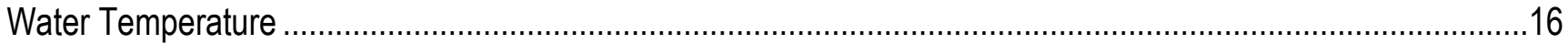

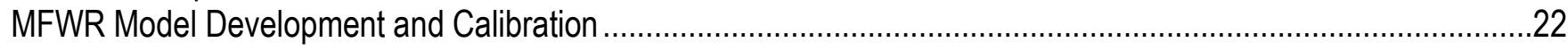

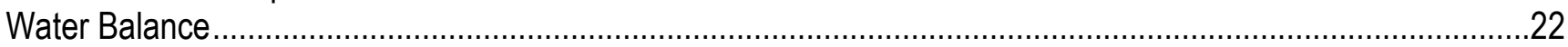

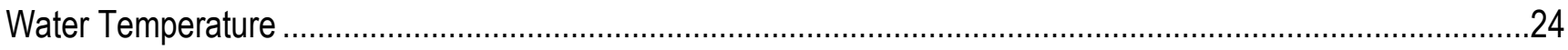

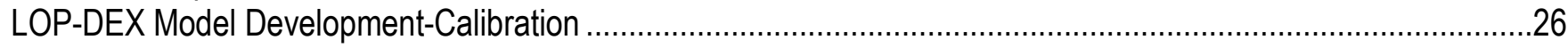

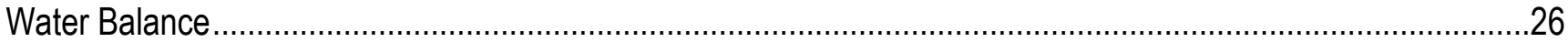

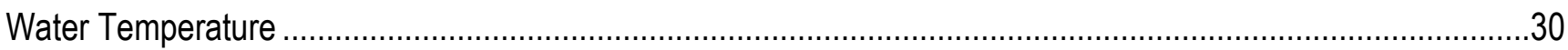

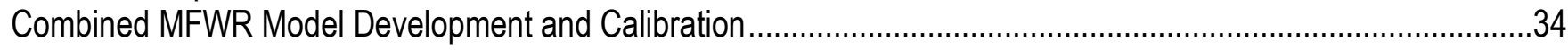

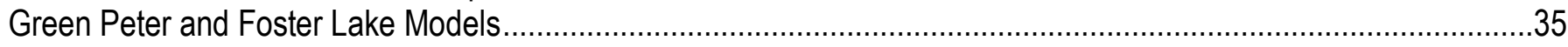

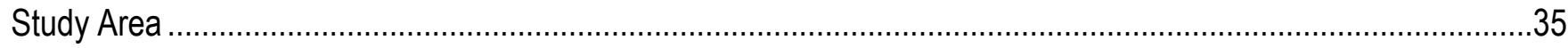

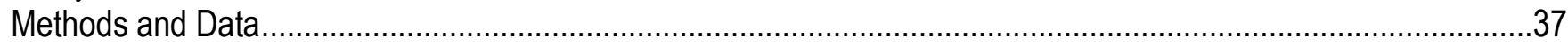

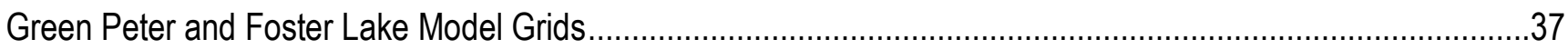

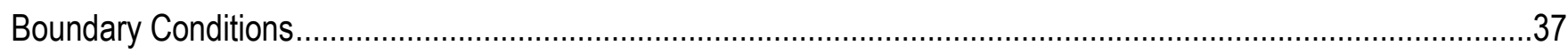

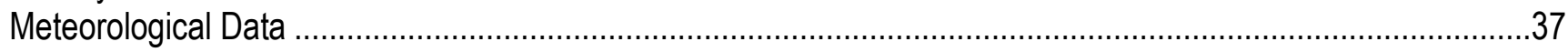

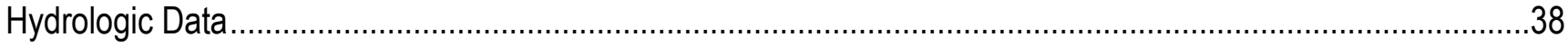

Inflow Water Temperature .............................................................................................................

Lake Profile Data and Outflow Water Temperature....................................................................................39

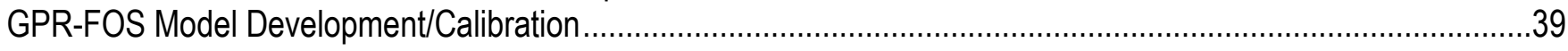

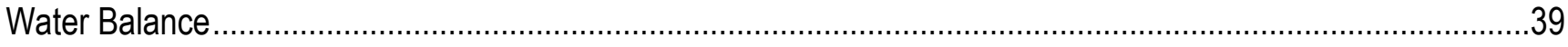

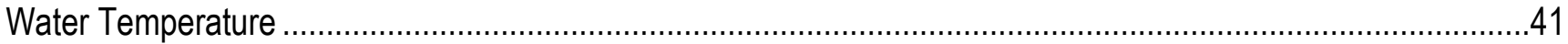

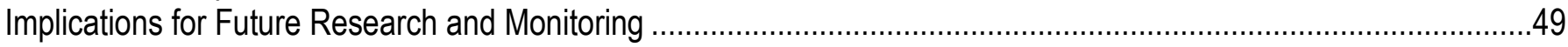

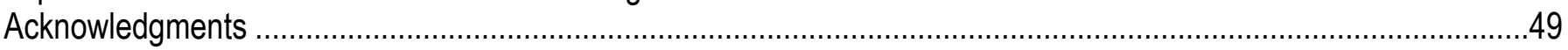

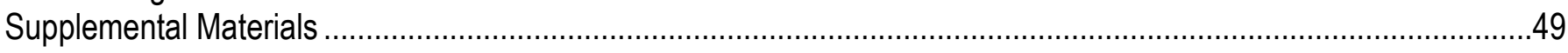

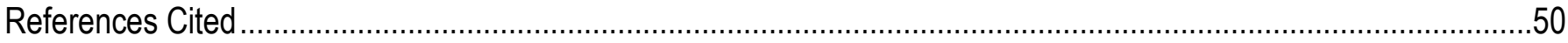

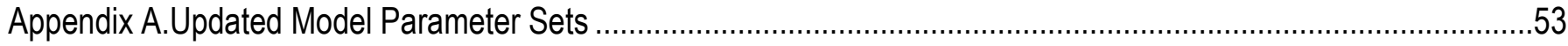




\section{Figures}

Figure 1. Map showing Willamette River Basin study area, Oregon. Circled areas indicate (A) the Middle Fork

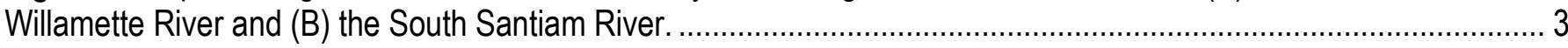

Figure 2. Map showing Middle Fork Willamette River study area, Oregon. ........................................................ 5

Figure 3. Diagram showing model grid for the Middle Fork Willamette River (RM 232.5-218.7), Oregon.................. 7

Figure 4. Graph showing total streamflow into Hills Creek Lake, Oregon, 2002, 2006, 2008, and 2011, along with historical percentiles of streamflow data into Hills Creek Lake for 1936-2011.

Figure 5. Graph showing estimated and measured temperature at U.S. Geological Survey stream-gaging station 14144800, North Fork of Middle Fork Willamette River, Oregon.

Figure 6. Graphs showing final water balance for Hills Creek Lake, Oregon, 2002, 2006, 2008, 2011, showing measured and modeled water-surface elevations along with the operational rule curve for the lake.

Figure 7. Diagrams showing elevations of operational goals and structures for Hills Creek, Lookout Point, Dexter, Green Peter, and Foster Dams, Oregon. Elevations refer to distance above mean sea level (USACE, 2009).

Figure 8. Graphs showing measured and modeled vertical temperature profiles in Hills Creek Lake, Oregon, 2002. (A) near the dam, and (B) near a mid-lake location.

Figure 9. Graphs showing measured and modeled water temperatures at specific depths in Hills Creek Lake near the dam, Oregon, 2011.

Figure 10. Graphs showing measured and modeled outflow temperatures and release rates from Hills Creek Lake $(\mathrm{HCL})$, Oregon, 2002 and 2011. Releases were through the power penstocks and the regulating outlet (RO).

Figure 11. Graphs showing model outflow and temperature for Middle Fork Willamette River and measured flows and temperatures at U.S. Geological Survey station 14148000, Oregon, 2002, 2006, 2008, and 2011.

Figure 12. Graphs showing measured and modeled water-surface elevations at Lookout Point Lake, Oregon, 2002, 2006,2008 , and 2011, along with the target rule curve for the lake.

Figure 13. Graphs showing measured and modeled water-surface elevations at Dexter Lake, Oregon, 2002, 2006 , 2008, and 2011, along with the target rule for the lake.

Figure 14. Graphs showing modeled release rates and water temperatures from Dexter Dam and measured streamflow and water temperatures at USGS station 14150000, located 2.6 miles downstream of Dexter Dam, Oregon, 2002, 2006, 2008, and 2011.

Figure 15. Graphs showing continuous measured and modeled water temperatures at specific depths in Lookout Point Lake near the dam, Oregon, 2011.

Figure 16. Graphs showing measured and modeled vertical temperature profiles in Lookout Point Lake near the dam, Oregon, 2002.

Figure 17. Graphs showing continuous measured and modeled water temperatures in Dexter Lake near the dam, Oregon, 2011.

Figure 18. Graphs showing measured and modeled vertical temperature profiles in Dexter Lake, Oregon, 2002. (A) near the dam, and (B) at a mid-lake location.

Figure 19. Map showing the Santiam River Basin, Oregon, including the South Santiam River Basin study area and key streamflow-gaging sites

Figure 20. Graphs showing measured and modeled forebay water-surface elevations in Green Peter Lake, Oregon, 2002, 2006, 2008, and 2011.

Figure 21. Graphs showing measured and modeled forebay water-surface elevations in Foster Lake, Oregon, 2002, 2006, 2008, and 2011. 
Figure 22. Graphs showing forebay thermistor string data for Green Peter Lake, Oregon, 2011, and model output at the same depths and times.

Figure 23. Graphs showing vertical profile temperature data for Green Peter Lake, Oregon, 2002, and model output at the same location and dates.

Figure 24. Graphs showing modeled outflow temperatures and measured water temperatures for Green Peter Lake, Oregon, just downstream of Green Peter Dam, and daily average total and regulating outlet (RO) release rates, 2002, 2006, 2008, and 2011.

Figure 25. Graphs showing forebay thermistor string data for Foster Lake, Oregon, 2011, and model output at the same depths and times.

Figure 26. Graphs showing modeled outflow temperatures and measured water temperatures for Foster Lake, Oregon, downstream of Foster Dam, and daily average flow through the power and spill outlets, 2002, 2006, 2008, and 2011.

\section{Tables}

Table 1. Percentiles of Hills Creek inflow, calendar years 1970-2011.

Table 2. Meteorological data sources for the Hills Creek Lake (HCL), Middle Fork Willamette River (MFWR), and Lookout Point-Dexter Lake models (LOP-DEX), Oregon.

Table 3. Streamflow and water-temperature data sources for the flow and temperature models, Oregon.................. 12

Table 4. Inflow-temperature estimation regression information and fit statistics.

Table 5. Differences between outlet structure characteristics in original and updated model for Hills Creek Lake, Oregon.

Table 6. Goodness-of-fit statistics comparing measured and modeled water temperatures for the Hills Creek Lake, Middle Fork Willamette River, and Lookout Point-Dexter Lakes models, Oregon.

Table 7. Selected model parameters used in the Hills Creek Lake, Middle Fork Willamette River, and Lookout PointDexter Lakes models, Oregon.

Table 8. Differences between outlet structure characteristics in original and updated Lookout Point-Dexter Lakes models, Oregon.

Table 9. Selected model parameter values used in the models for Green Peter and Foster Lakes,Oregon.

Table 10. Model goodness-of-fit statistics for water temperature for Green Peter and Foster Lakes, Oregon.

Table A1. Differences in model parameter values between the original West Consultants models and the updated U.S. Geological Survey Hills Creek Lake and Lookout Point and Dexter Lakes models, Oregon

Table A2. Differences between meteorological data sources in the original West Consultants models and the updated

U.S. Geological Survey Hills Creek Lake and Lookout Point and Dexter Lakes models, Oregon.

Table A3. Differences in model parameter values between the original West Consultants models and the updated

U.S. Geological Survey Green Peter Lake and Foster Lake models, Oregon 


\section{Conversion Factors, Datums, and Abbreviations and Acronyms}

\section{Conversion Factors}

Inch/Pound to SI

\begin{tabular}{lcl}
\hline \multicolumn{1}{c}{ Multiply } & By & \multicolumn{1}{c}{ To obtain } \\
\hline inch (in.) & 2.54 & centimeter $(\mathrm{cm})$ \\
foot (ft) & 0.3048 & meter $(\mathrm{m})$ \\
mile (mi) & 1.609 & kilometer $(\mathrm{km})$ \\
square mile $\left(\mathrm{mi}^{2}\right)$ & 2.590 & square $\mathrm{kilometer}\left(\mathrm{km}^{2}\right)$ \\
acre & 4,047 & square meter $\left(\mathrm{m}^{2}\right)$ \\
acre-foot (acre- $\mathrm{ft})$ & 1,233 & cubic meter $\left(\mathrm{m}^{3}\right)$ \\
cubic foot per second $\left(\mathrm{ft}^{3} / \mathrm{s}\right)$ & 0.02832 & cubic meter $\mathrm{per} \mathrm{second}\left(\mathrm{m}^{3} / \mathrm{s}\right)$ \\
square foot per second $\left(\mathrm{ft}^{2} / \mathrm{s}\right)$ & 0.0929 & square meter per second $\left(\mathrm{m}^{2} / \mathrm{s}\right)$ \\
\hline
\end{tabular}

SI to Inch/Pound

\begin{tabular}{lll}
\multicolumn{1}{c}{ Multiply } & \multicolumn{1}{c}{ By } & \multicolumn{1}{c}{ To obtain } \\
\hline centimeter $(\mathrm{cm})$ & 0.3937 & inch (in.) \\
meter $(\mathrm{m})$ & 3.281 & foot $(\mathrm{ft})$ \\
kilometer $(\mathrm{km})$ & 0.6214 & mile $(\mathrm{mi})$ \\
square kilometer $\left(\mathrm{km}^{2}\right)$ & 0.3861 & square mile $\left(\mathrm{mi}^{2}\right)$ \\
square meter $\left(\mathrm{m}^{2}\right)$ & 0.0002471 & acre \\
cubic meter $\left(\mathrm{m}^{3}\right)$ & 0.0008107 & acre-foot $(\mathrm{acre}-\mathrm{ft})$ \\
meter per second $(\mathrm{m} / \mathrm{s})$ & 3.281 & foot per second $(\mathrm{ft} / \mathrm{s})$ \\
cubic meter per second $\left(\mathrm{m}^{3} / \mathrm{s}\right)$ & 35.31 & cubic foot per second $\left(\mathrm{ft}^{3} / \mathrm{s}\right)$ \\
square meter per second $\left(\mathrm{m}^{2} / \mathrm{s}\right)$ & 10.764 & square foot per second $\left(\mathrm{ft}^{2} / \mathrm{s}\right)$ \\
\hline
\end{tabular}

Temperature in degrees Celsius $\left({ }^{\circ} \mathrm{C}\right)$ may be converted to degrees Fahrenheit $\left({ }^{\circ} \mathrm{F}\right)$ as follows: $\mathrm{F}=\left(1.8 \times{ }^{\circ} \mathrm{C}\right)+32$

Temperature in degrees Fahrenheit $\left({ }^{\circ} \mathrm{F}\right)$ may be converted to degrees Celsius $\left({ }^{\circ} \mathrm{C}\right)$ as follows: $\mathrm{C}=\left({ }^{\circ} \mathrm{F}-32\right) / 1.8$

\section{Datums}

Unless otherwise noted, vertical coordinate information is referenced to the North American Vertical Datum of 1988 (NAVD 88).

Horizontal coordinate information is referenced to the North American Datum of 1983 (NAD 83).

Elevation, as used in this report, refers to distance above the vertical datum. 


\section{Abbreviations and Acronyms}

\begin{tabular}{ll}
\hline $\begin{array}{c}\text { Abbreviation or } \\
\text { acronym }\end{array}$ & \\
\hline CE-QUAL-W2 & Two-dimensional hydrodynamic and water-quality model \\
CY & Calendar Year \\
DEX & Dexter Lake \\
FOS & Foster Lake \\
FWSO & Foster Dam Weather Station \\
GPR & Green Peter Lake \\
HCL & Hills Creek Lake \\
HCWO & Hills Creek Dam Weather Station \\
LOP & Lookout Point Lake \\
LOP-DEX & Lookout Point-Dexter Lakes \\
LPWO & Lookout Point Dam Weather Station \\
MAE & mean absolute error \\
ME & mean error \\
NFMFWR & North Fork of Middle Fork Willamette River \\
MFWR & Middle Fork Willamette River \\
NCDC & National Climatic Data Center (National Oceanic and Atmospheric Administration) \\
ODEQ & Oregon Department of Environmental Quality \\
QDT & distributed tributary inflow \\
RM & river mile \\
RMSE & root mean square error \\
RO & Regulating Outlet \\
RPA & Reasonable and Prudent Alternative \\
SRML & Solar Radiation Monitoring Laboratory (University of Oregon) \\
TDT & distributed tributary temperature \\
USACE & U.S. Army Corps of Engineers \\
USGS & U.S. Geological Survey \\
\hline
\end{tabular}


This page is intentionally blank. 


\title{
Development of CE-QUAL-W2 Models for the Middle Fork Willamette and South Santiam Rivers, Oregon
}

\author{
By Norman L. Buccola, Adam J. Stonewall, Yoonhee Kim, Annett B. Sullivan, and Stewart A. Rounds
}

\section{Abstract}

Hydrodynamic (CE-QUAL-W2) models of Hills Creek Lake (HCL), Lookout Point Lake (LOP), and Dexter Lake (DEX) on the Middle Fork Willamette River (MFWR), and models of Green Peter Lake and Foster Lake on the South Santiam River systems in western Oregon were updated and recalibrated for a wide range of flow and meteorological conditions. These CE-QUALW2 models originally were developed by West Consultants, Inc., for the U.S. Army Corps of Engineers. This study by the U.S. Geological Survey included a reassessment of the models' calibration in more recent years-2002, 2006, 2008, and 2011 — categorized respectively as low, normal, high, and extremely high flow calendar years. These years incorporated current damoperation practices and more available data than the time period used in the original calibration. Modeled water temperatures downstream of both HCL and LOP-DEX on the MFWR were within an average of 0.68 degree Celsius $\left({ }^{\circ} \mathrm{C}\right)$ of measured values; modeled temperatures downstream of Foster Dam on the South Santiam River were within an average of $0.65^{\circ} \mathrm{C}$ of measured values. A new CE-QUAL-W2 model was developed and calibrated for the riverine MFWR reach between Hills Creek Dam and the head of LOP, allowing an evaluation of the flow and temperature conditions in the entire MFWR system from HCL to Dexter Dam.

The complex bathymetry and long residence time of HCL, combined with the relatively deep location of the power and regulating outlet structures at Hills Creek Dam, led to a HCL model that was highly sensitive to several outlet and geometric parameters related to dam structures (STR TOP, STR BOT, STR WIDTH). Release temperatures from HCL were important and often persisted downstream as they were incorporated in the MFWR model and the LOPDEX model (downstream of MFWR). The models tended to underpredict the measured temperature of water releases from Dexter Dam during the late-September-through-December drawdown period in 2002, and again (to a lesser extent) in 2011, but simulations were much more accurate in 2006 and 2008. This episodic model bias may have been a result of hot, dry conditions; lower lake elevations; and earlier drawdown at both HCL and LOP in 2002. These dry conditions in 2002 may have contradicted assumptions inherent in the estimation of certain model inputs, such as unmeasured inflows and water temperatures, which may respond differently during dry years than during normal and wet years.

This report documents the development and calibration of new and revised flow and watertemperature models for riverine and reservoir reaches in the Middle Fork Willamette River and South Santiam River systems. Methods and model parameter values were established for the accurate simulation of flows and temperatures in these systems under current conditions. By extension, these models should be able to accurately simulate flows and temperatures under potential future conditions in which dam operations and dam outlet structures may be changed as part of a strategy to improve habitat, fish passage, and temperature conditions for endangered fish. 


\section{Introduction}

The existence and operation of 13 dams in the Willamette River Basin, Oregon (fig. 1), owned and operated by the U.S. Army Corps of Engineers (USACE), have altered the natural hydrological and thermal regime throughout the basin (Gregory and others, 2007). Discharge from many of these dams is unusually warm in autumn, which contributes to high mortality rates of incubating eggs of spring Chinook Salmon (Oregon Department of Fish and Wildlife and National Marine Fisheries Service Northwest Region, 2011). Reasonable and Prudent Alternatives (RPAs) specified in the 2008 Biological Opinion from the National Marine Fisheries Service require the evaluation and implementation of feasible operational and (or) structural modifications of the dams to address flow and water-quality effects of USACE projects on Upper Willamette River Chinook Salmon and winter Steelhead (National Marine Fisheries Service, 2008). The objective of these RPAs is to improve habitat conditions for anadromous fish species listed under the Endangered Species Act that will result in increased egg survival and increased survival of adult and juvenile life stages, causing increases in abundance and productivity.

Mortality rates for spring Chinook Salmon at water temperatures greater than 16.0 and $17.0{ }^{\circ} \mathrm{C}$ can exceed 50 and 98 percent, respectively. Temperatures downstream of dams on the Middle Fork Willamette River can exceed these water temperatures from the middle of the spawning season (September) through mid-October.

CE-QUAL-W2 models of Hills Creek, Lookout Point, and Dexter Lakes on the Middle Fork Willamette River (fig. 1, area designated by "A"), and Green Peter and Foster Lakes on the South Santiam River (fig. 1, area designated by "B"), were developed to help manage dam releases, understand the effects of the dams on stream temperatures, and plan strategies that will result in water temperatures less detrimental to Chinook Salmon and winter Steelhead populations (West Consultants, Inc., 2004a, 2004b, 2005). CE-QUAL-W2 is a twodimensional, longitudinal-vertical, hydrodynamic and water-quality model constructed and maintained by USACE and Portland State University. The model assumes lateral homogeneity within each cell of the grid, and, therefore, is best suited for relatively narrow water bodies that tend to stratify, resulting in predominantly longitudinal and vertical waterquality gradients. CE-QUAL-W2 has been applied to rivers (Annear and others, 2005), reservoirs (Hanna and others, 1999; Bartholow and others, 2000; Buccola and others, 2012), estuaries (Bowen and Hieronymus, 2003), and combinations thereof (Rounds, 2010; Sullivan and others, 2011).

\section{Purpose and Scope}

This report documents the updated calibration and further development of CEQUAL-W2 reservoir models on the Middle Fork Willamette and South Santiam Rivers, as well as the construction of a CE-QUAL-W2 riverine model between Hills Creek Dam and Lookout Point Lake on the Middle Fork Willamette River. The reservoir models originally were developed and calibrated by West Consultants to include dam operations as recent as 2002, but those models required further testing and updates. The main objectives of this study were to:

- Update the calibration of reservoir models on the Middle Fork Willamette River (Hills Creek Lake and Lookout Point-Dexter Lakes) and the South Santiam River (Green Peter and Foster Lakes) for calendar years 2002, 2006, 2008, and 2011 to include current (2013) dam operations and expanded temperature monitoring that has occurred since the original development of these models.

- Develop a CE-QUAL-W2 temperature model for the riverine reach of the Middle Fork Willamette River between Hills Creek Dam (river mile [RM] 232.5) and the boat ramp at the head of Lookout Point Lake (RM 218.7). 


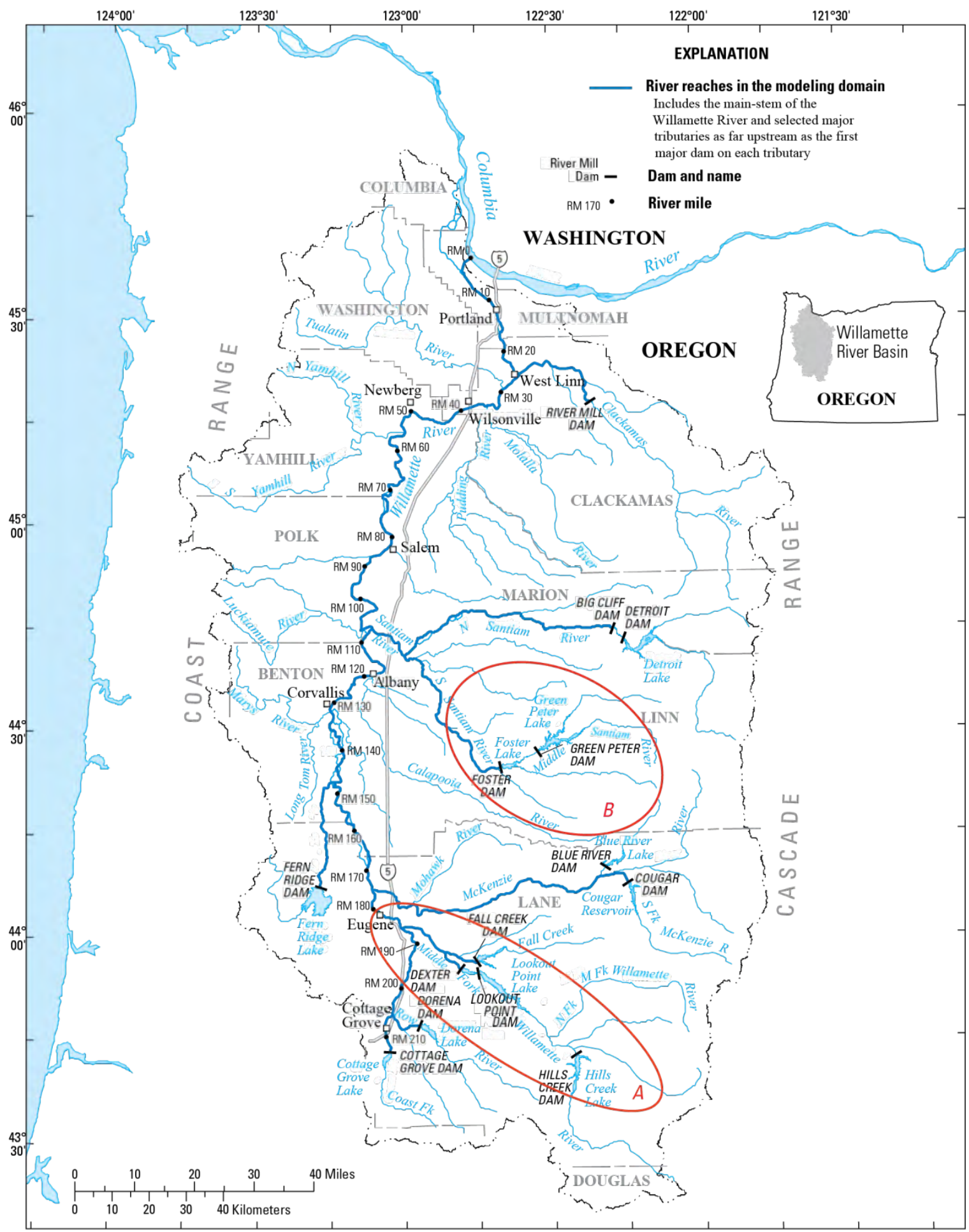

Base map modified from U.S. Geological Survey and other digital data sets $(1: 2,000,000 ; 1: 100,000)$. Projection: Oregon Lambert Conformal Conic, NAD1983, NAVD1988.

Figure 1. Map showing Willamette River Basin study area, Oregon. Circled areas indicate (A) the Middle Fork Willamette River and (B) the South Santiam River. 
- Link and calibrate the combined models of Hills Creek Lake, the Middle Fork Willamette River, Lookout Point Lake, and Dexter Lake.

- Describe and document the new and updated CE-QUAL-W2 models, including construction, calibration, sensitivity analysis, departures from the original West Consultants models, and results.

Two study areas were investigated: (1) the Middle Fork Willamette models, which include Hills Creek Lake and all Middle Fork Willamette River reaches downstream to the outflow at Dexter Dam; and (2) the South Santiam model, which covers Green Peter Lake on the Middle Fork Santiam River downstream to the outflow at Foster Dam on the South Santiam River.

Documentation of the previously existing CE-QUAL-W2 reservoir hydrological and temperature models is limited in this report to significant changes or updates from the original model development previously documented by West Consultants (2004a, 2004b, 2005).

\section{Middle Fork Willamette River Models}

\section{Study Area}

The Middle Fork Willamette River is located in the southern, most upstream reaches of the Willamette River Basin in western Oregon (figs. 1 and 2). The river generally runs northwesterly and flows through or near the communities of Oakridge, Westfir, Dexter, and Lowell before joining with the Coast Fork Willamette River to form the Willamette River near Eugene and Springfield, Oregon. Major tributaries of consideration include Hills Creek, Salt Creek, Salmon Creek, the North Fork of the Middle Fork Willamette River, and Fall Creek. The river is impounded by three dams (in downstream order)—Hills Creek Dam, Lookout Point Dam, and Dexter Dam.

Hills Creek Dam is an earthen dam that is $304 \mathrm{ft}(92.7 \mathrm{~m})$ in height; it was completed in 1961. Hills Creek Lake impounds 355,500 acre-ft $\left(4.39 \times 10^{8} \mathrm{~m}^{3}\right)$ of water at a full pool elevation of $1,543 \mathrm{ft}(470 \mathrm{~m})$. Lookout Point Dam is an earth and gravel-fill dam with a concrete gated spillway; the dam is $276 \mathrm{ft}(84 \mathrm{~m})$ in height and was completed in 1954. Lookout Point Lake is the largest reservoir in the Willamette River Basin, impounding 455,800 acre- $\mathrm{ft}\left(5.89 \times 10^{8} \mathrm{~m}^{3}\right)$ of water at a full pool elevation of $929 \mathrm{ft}(283 \mathrm{~m})$. Dexter Dam, also an earth and gravel-fill dam with a concrete gated spillway, is $93 \mathrm{ft}(28.3 \mathrm{~m})$ in height and was completed in 1954. Dexter Lake impounds 27,500 acre- $\mathrm{ft}\left(3.39 \times 10^{7} \mathrm{~m}^{3}\right)$ of water at a full pool elevation of $695 \mathrm{ft}(212 \mathrm{~m})$. Dexter Dam is a re-regulating dam that buffers the sometimes irregular flows released from Lookout Point Dam. These dams were constructed for flood-damage minimization, hydropower, and recreation, as well as downstream flow augmentation during the lowflow summer season.

The Middle Fork Willamette River Basin has a drainage area of $1,001 \mathrm{mi}^{2}\left(2,593 \mathrm{~km}^{2}\right)$. Elevation ranges from $618 \mathrm{ft}(188 \mathrm{~m})$ at the U.S. Geological Survey (USGS) streamflow gage (14150000) near Dexter to $8,744 \mathrm{ft}(2,665 \mathrm{~m})$ at Diamond Peak in the Cascade Range. The reach of interest begins at the head of Hills Creek Lake and extends downstream through Lookout Point and Dexter Lakes to Dexter Dam, a total of 36.2 river miles (58.3 river kilometers).

The Middle Fork Willamette River Basin has a temperate marine climate typified by dry summers and wet winters. Most precipitation falls between November and April, and summers and early autumn are usually dry. Precipitation in the study area averages $62.4 \mathrm{in} / \mathrm{yr}(158 \mathrm{~cm} / \mathrm{yr})$ (U.S. Geological Survey, 2012a). At elevations greater than $4,000 \mathrm{ft}(1,219 \mathrm{~m})$, about 35 percent of annual precipitation falls as snow (Lee and Risely, 2002). Diurnal and annual air temperature ranges are relatively small for this latitude, owing largely to the dominance of eastward-moving marine airflow patterns. The average maximum daily air temperature for the study area is $13.9^{\circ} \mathrm{C}$, and the average minimum daily air temperature is $2.1^{\circ} \mathrm{C}$ (U.S. Geological Survey, 2012a). 


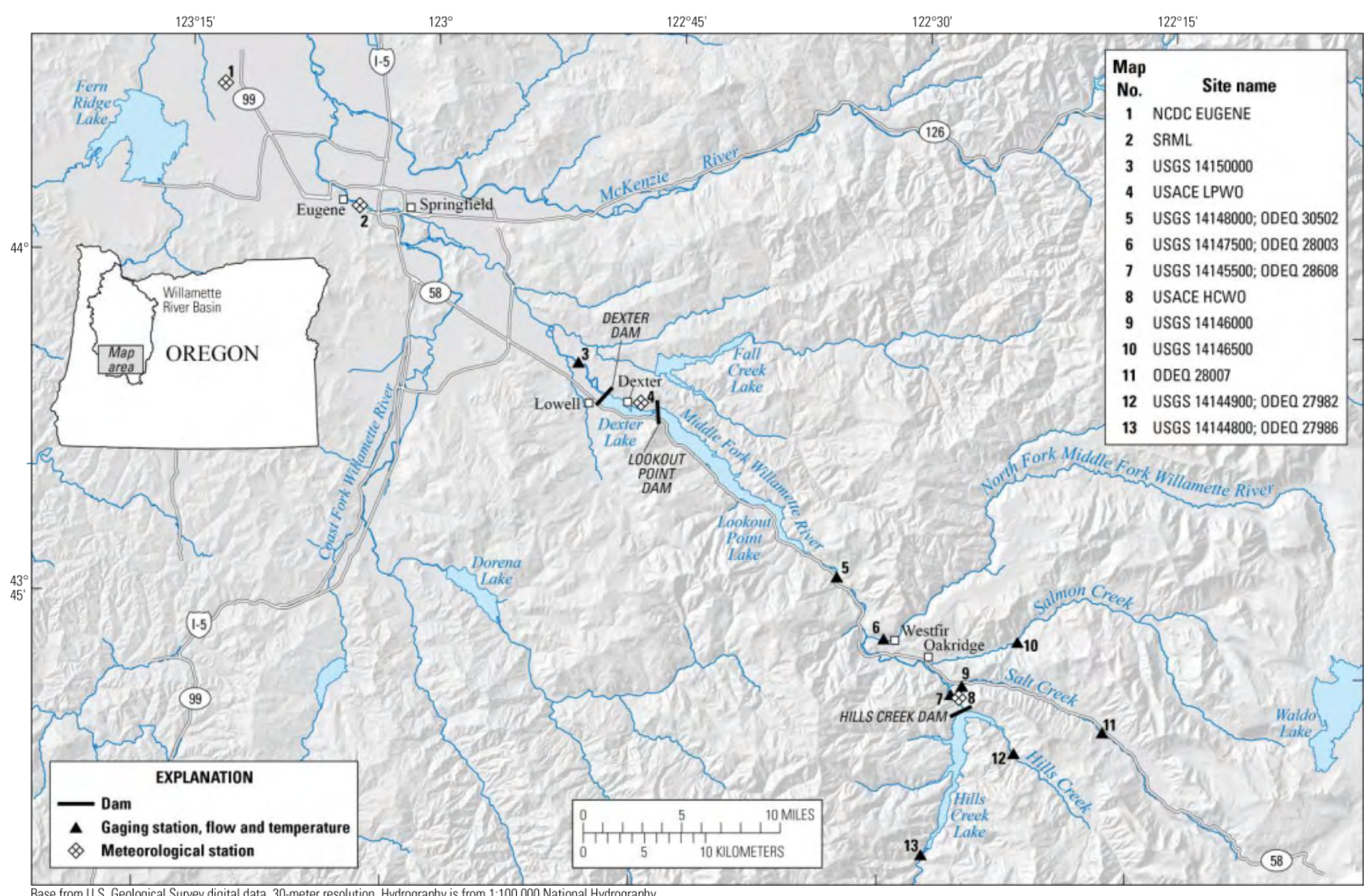

Dataset. Roads are from Oregon Transportation Network Public Release (2012), Department of Transportation. Spatial

Reference System: NAD 19832011 UTM Zone 11N, Datum North American Datum of 1983*2011)

Figure 2. Map showing the Middle Fork Willamette River Basin, Oregon, including the Middle Fork Willamette River Basin study area and key streamflow-gaging sites.

For the entire Middle Fork Willamette River Basin (both the study area and downstream to its confluence with the Coast Fork Willamette River), 94.7 percent of land use is forest ( 72 percent public, and 28 percent private) (Middle Fork Willamette Watershed Council, 2012). Other land uses include water (1.9 percent), nonrange agricultural (1.3 percent), urban and residential (1.3 percent) and wetlands $(0.5$ percent).The study area is mostly rural. The entire Middle Fork Willamette River Basin has a population of only 24,000 residents (Middle Fork Willamette Watershed Council, 2012).

\section{Methods and Data}

Model Description

The Middle Fork Willamette and South Santiam River models were developed using the CE-QUAL-W2 model, version 3.7, revision 12 (Cole and Wells, 2011). Initial development of the CE-QUAL-W2 reservoir models used in this study was completed by West Consultants as follows: Hills Creek Lake (HCL) (West Consultants, Inc., 2004a), and Lookout Point and Dexter Lakes (LOP-DEX) (West Consultants, Inc., 2004b); further details can be found in those references.

Development and calibration of these models generally occur in a three-step procedure: (1) creating the model grids, (2) compiling or 
estimating boundary conditions, and (3) calibrating lake elevations, streamflow and circulation, and temperature. Model bathymetric grids for the HCL and LOP-DEX models remained unchanged from the original West Consultants models, but many new parameter values and datasets were used to update and improve the calibration (appendix A).

\section{Model Grids}

The longitudinal dimension (upstream and downstream) of the CE-QUAL-W2 model grid is constructed from model segments. Each segment contains layers of defined width that either increase or remain constant from the bottom of the channel to the top of the grid. Collections of segments can be grouped together into "branches." Branches typically are used to define specific reaches of river, potentially including tributaries. Similarly, one or more branches can be grouped together to form "waterbodies," the largest building blocks of the model grid. Each waterbody can have unique sets of meteorological conditions, hydrologic coefficients, and structures. In effect, a model with more than one waterbody is composed of separate models where the output of the mostupstream waterbody model is the input for the next waterbody model downstream.

The HCL model is composed of a single waterbody with four branches. The HCL model grid contains 43 segments (ranging from 259.7 to $497.4 \mathrm{~m}$ in length) and 178 layers $(0.5 \mathrm{~m}$ in height). The LOP-DEX model incorporated 2 waterbodies (a single branch for each waterbody) in a single model. The LOP grid (waterbody 1 of LOP-DEX) is composed of 35 segments $(503.5 \mathrm{~m}$ in length) and 74 layers ( $1 \mathrm{~m}$ in height), although the DEX grid (waterbody 2 of LOP-DEX) is composed of 19 segments (249.1 $\mathrm{m}$ in length) and 74 layers (1 $\mathrm{m}$ in height). Between Hills Creek Dam and the head of Lookout Point Lake, however, is an almost 15-mi reach of the Middle Fork Willamette River that was not covered by a model, making it difficult to use the HCL and LOP-DEX models together. In this study, a separate and new CE-QUAL-W2 model was developed to simulate the streamflow and temperature conditions in the Middle Fork Willamette River between Hills Creek Dam and Lookout Point Lake.

\section{Middle Fork Willamette River Model from River Mile 232.5 to 217.7}

The Middle Fork Willamette River (MFWR) model grid (fig. 3) was developed in several steps. First, data from the two long-term USGS stream-gaging stations (14145500 and 14148000) located along the stretch of river included in the model were evaluated. Cross sections for the model were developed using historical, highstreamflow measurements of the channel shape taken from cableways placed across the river.

Second, aerial photography of the reach was evaluated to allow the inclusion of variations in the river's surface width and other characteristics. Measured gage height at the two streamgages on the date the aerial photographs were taken was used to calculate water depths for 28 equidistant reaches along the river. River width and orientation were estimated using the aerial photographs. Channel shape and segment elevation were estimated using Geographic Information System (GIS) techniques, extrapolating the channel shapes from the gage locations. Initial channel cross-sectional shapes, however, were determined to be too narrow near the base, and a more gradual decrease in width was integrated into the channel shape by establishing minimum channel widths based on a combination of aerial photography and the cross sections developed from the two streamgaging stations.

The 28 river reaches originally were each 0.5 $\mathrm{mi}(804.7 \mathrm{~m})$ in length. Subsequent analysis revealed that specific segments were too steep for the CE-QUAL-W2 model to run without failing. The steepest segments were divided into smaller segments until the model became sufficiently stable. The resulting MFWR model grid (fig. 3) contained 84 active segments in one waterbody. 


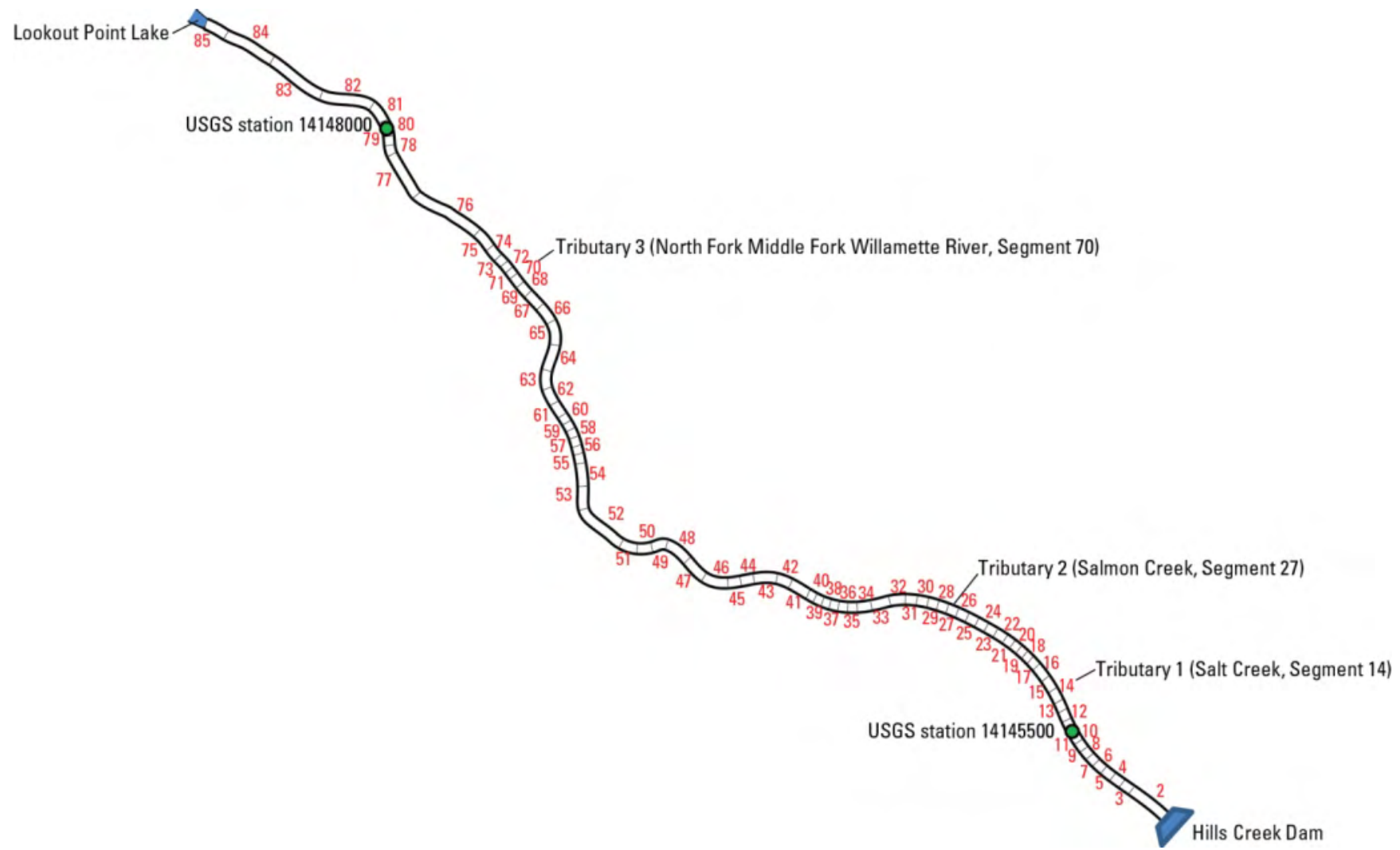

Figure 3. Diagram showing model grid for the Middle Fork Willamette River (RM 232.5-218.7), Oregon.

Segments ranged in length from 134.11 to 804.67 $\mathrm{m}$, with an average length of $265 \mathrm{~m}$. Total model length was $22.3 \mathrm{~km}$ (13.8 $\mathrm{mi}$ ) and covered the length of the Middle Fork Willamette from the outlet at Hills Creek Dam to about 1 mi upstream of the Hampton Boating dock, near the confluence of Rock Creek (RM 232.5 to 218.7). Layer heights were fixed at $0.2 \mathrm{~m}$. Tributaries of Salt Creek, Salmon Creek, and the North Fork of the Middle Fork Willamette River (NFMFWR) flow into the MFWR model in segments 14, 27 and 70, respectively. The MFWR model reach has a mean slope of $0.0049 \mathrm{~m} / \mathrm{m}$.

\section{Boundary Conditions}

\section{Selection of Time Periods}

In order to consider a wide range of hydrologic and meteorological conditions within the Middle Fork Willamette River Basin, calendar years were selected that represented relatively wet, normal, and dry conditions. The calendar year was selected instead of the water year to compare water temperatures that were linked with dam operations, which are based on the calendar year. calendar years were evaluated for the amount of streamflow and temperature data available within the basin. Data-rich years are easier to calibrate, as fewer inputs need to be estimated and model results can be calibrated to measured conditions. The years 1970 through 2011 were adopted for consideration, representing the 33 years of data simulated with the West Consultants models (through 2002) and more recent years. calendar years were evaluated using the following criteria:

- Comparability of streamflow to the historical percentiles designated for wet (75th percentile), normal (median), and dry (25th percentile) years; 
- Availability and frequency of streamflow data upstream and downstream of all model reaches;

- Availability and frequency of stream temperature data upstream and downstream of all model reaches;

- Availability of vertical temperature profile data in all three reservoirs; and

- Availability of streamflow and stream temperature data for major tributaries entering the system.

Availability of streamflow data was the least restrictive of the criteria. Between the USGS streamgages 14144800 (MFWR near Oakridge), 14145500 (MFWR upstream of Salt Creek, near Oakridge), 14148000 (downstream of NFMFWR near Oakridge), and 14150000 (MFWR near Dexter) (fig. 2), all but the first station had streamflow data available for the entire study period. Additionally, estimates of streamflow inputs and outputs for each reservoir system were available from USACE for the entire study period.
Temperature data were less abundant than streamflow data. Periods with the most temperature data available included 1978-1982, when the most USGS temperature gages in the study area were active; 2002, when temperature data from the Oregon Department of Environmental Quality (ODEQ) were most actively collected; and 2011. Discrete vertical profile measurements of water temperature in the reservoirs were available for $1971,1975-76$, and 2002, while continuous time-series profile measurements were made in 2010-11. USGS streamflow and temperature data were available at a daily frequency prior to about 1987, and at frequencies between hourly and every 15 minutes after 1987.

The year 2002 was selected to represent dry conditions. In addition to having ample temperature and streamflow data, 2002 was one of only six of the potential years evaluated with temperature profile data available. Finally, 2002 was modeled by West Consultants in their original model development work, allowing for a comparison of model results to the updated models from this study. The year 2002 was characterized by a mild spring and a relatively warm and dry summer (fig. 4, table 1). 


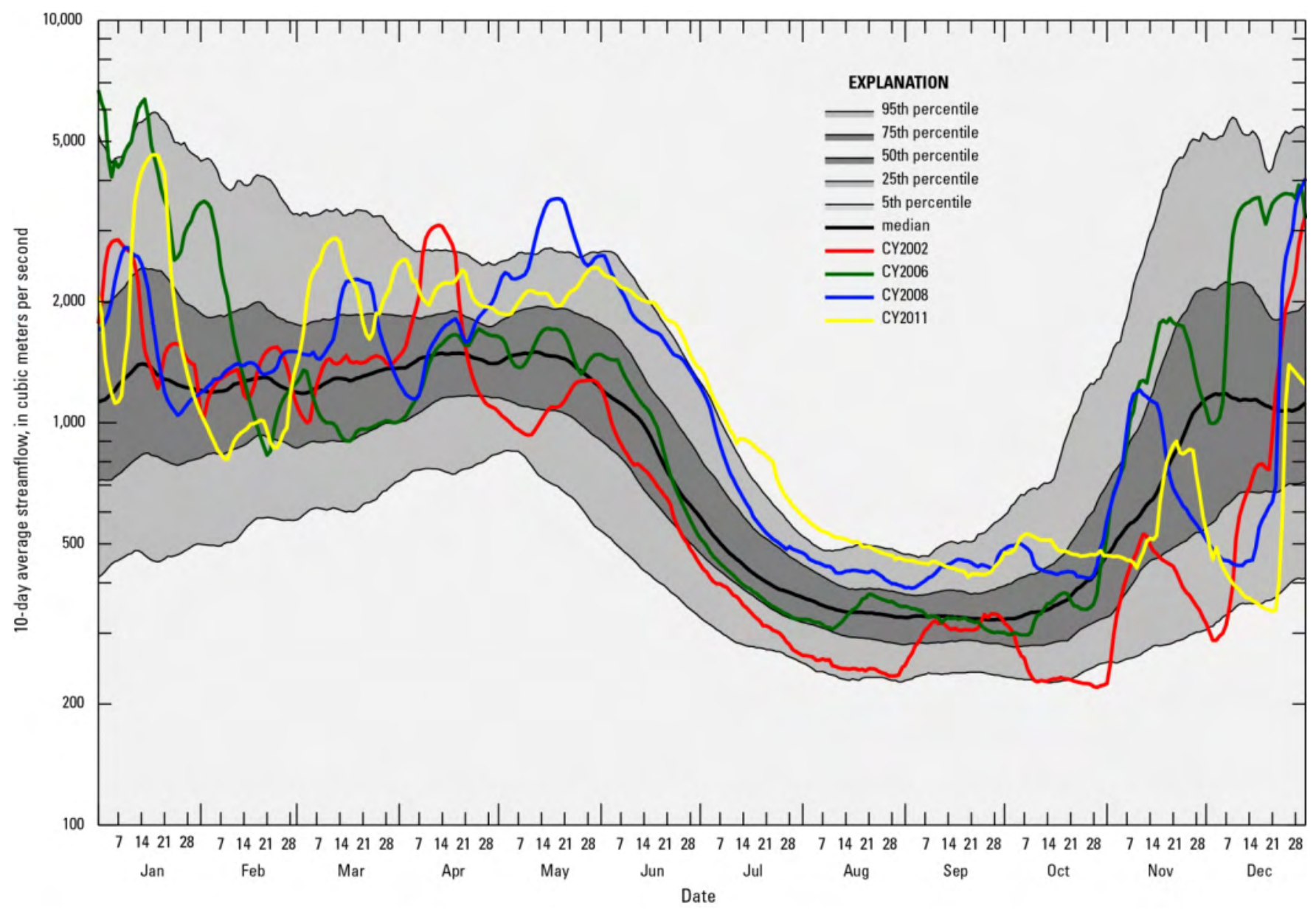

Figure 4. Graph showing total streamflow into Hills Creek Lake, Oregon, 2002, 2006, 2008, and 2011, along with historical percentiles of streamflow data into Hills Creek Lake for 1936-2011.

Table 1. Percentiles of Hills Creek inflow, calendar years 1970-2011.

\begin{tabular}{cccccc}
\hline Year & $\begin{array}{c}\text { Full calendar } \\
\text { year }\end{array}$ & $\begin{array}{c}\text { January- } \\
\text { September }\end{array}$ & $\begin{array}{c}\text { Spring flow: } \\
\text { March-May }\end{array}$ & $\begin{array}{c}\text { Summer flow: } \\
\text { June-September }\end{array}$ & $\begin{array}{c}\text { October- } \\
\text { December }\end{array}$ \\
\hline 2002 & 0.18 & 0.32 & 0.39 & 0.21 & 0.19 \\
2006 & 0.78 & 0.71 & 0.29 & 0.53 & 0.78 \\
2008 & 0.71 & 0.81 & 0.90 & 0.90 & 0.40 \\
2011 & 0.90 & 0.88 & 0.91 & 0.99 & 0.08 \\
\hline
\end{tabular}

Spring and summer of 2006 were selected to represent average (normal) streamflow conditions. Although 2006 was not rich in data, late spring and summer streamflow conditions during 2006 were usually near the median historical flow (fig. 4), making most of 2006 representative of average conditions.
Spring and summer of 2008 were representative of historical wet conditions. Similar to 2006, 2008 had incomplete data, but more temperature data were available in 2008 than in other calendar years that were considered representative of wet conditions. Late spring and early summer streamflows in 2008 were typically 
near or above the 75 th percentile (fig. 4).

Towards the end of both 2006 and 2008, streamflow levels began to deviate from summer and early autumn conditions. Beginning in early November 2008, drier conditions resulted in lessthan-average streamflows for most of December.

Conditions from 2011 did not fit well with any of the three categories used for data selection-dry, normal, or wet. An especially wet spring in 2011 resulted in high summer flows, which were followed by a dry autumn. The year 2011 was the most data-rich of all calendar years considered for selection; therefore, 2011 was added to the study so that at least one data-rich calendar year was available to aid in the calibration of the models.

Meteorological Data

CE-QUAL-W2 requires time series inputs of six meteorological parameters: air temperature, dew-point temperature, wind speed, wind direction, cloud cover, and solar radiation. Meteorological data for the models were obtained from four sources (table 2):

\section{USACE Hills Creek Dam Weather Station (HCWO),}

2. USACE Lookout Point Dam Weather Station (LPWO),

3. National Oceanic and Atmospheric Administration site at the Eugene airport (National Climatic Data Center [NCDC]), and

4. University of Oregon Solar Radiation Monitoring Laboratory (SRML) in Eugene.

All datasets were screened for outliers, and when possible, compared with similar datasets from nearby locations.
Table 2. Meteorological data sources for the Hills Creek Lake (HCL), Middle Fork Willamette River (MFWR), and Lookout Point-Dexter Lake models (LOP-DEX), Oregon.

[Abbreviations: NCDC, National Climatic Data Center; EUG, Eugene; USACE, U.S. Army Corps of Engineers; HCWO, Hills Creek weather station; LPWO, Lookout Point weather station]

\begin{tabular}{lcc}
\hline \multicolumn{1}{c}{ Parameters } & HCL & $\begin{array}{c}\text { MFWR, } \\
\text { LOP-DEX }\end{array}$ \\
\hline \multirow{4}{*}{$\begin{array}{l}\text { Air temperature, dew } \\
\text { point temperature }\end{array}$} & NCDC EUG & $\begin{array}{c}\text { NCDC EUG } \\
\text { regression }\end{array}$ \\
& $\left(2002^{1}\right)$, & $\left(2002^{1}\right)$, \\
& USACE HCWO & USACE \\
& & LPWO
\end{tabular}

Wind speed, wind direction, cloud NCDC EUG NCDC EUG cover, solar radiation

\footnotetext{
${ }^{1}$ In 2002, NCDC EUG data from 2006, 2008, 2009, and 2011 were used to estimate USACE LPWO and HCWO
}

Air temperature data were retrieved from the USACE Dataquery website (U.S. Army Corps of Engineers, 2012a) for the weather stations at Hills Creek Dam (HCWO) and Lookout Point Dam (LPWO), and converted to degrees Celsius. For the MFWR model, comparisons of model results were made using data from HCWO and LPWO, and it was determined that the data from LPWO provided better results.

Dew-point temperature can be estimated from air temperature and relative humidity with the following equation (Lawrence, 2005):

$T_{d p}=T_{a}-\frac{100-R H}{5}$

where

$\mathrm{T}_{\mathrm{dp}}=$ Dew point temperature in degrees Celsius; $\mathrm{T}_{\mathrm{a}}=$ Air temperature in degrees Celsius; and $\mathrm{RH}=$ Relative humidity in percent.

Dew-point temperatures were calculated using this equation and air temperature and relative humidity data from HCWO and LPWO.

Four sources were considered for wind speed data-LPWO, HCWO, the Primet station 
operated by the U.S. Forest Service in the H.J. Andrews Experimental Forest, and the weather station at the Eugene airport. Despite their relative proximity, the wind speeds recorded at the four sites were dissimilar. West Consultants, Inc. (2004a, 2004b) noted that the wind speeds at both Hills Creek and Lookout Point Dams are subject to updrafts at the dam faces and, therefore, those sites do not provide reliable measurements of wind speed or direction for their respective areas. Similarly, the Primet station is located in a forest clearing (West Consultants, Inc., 2004a). Therefore, wind speeds at the Primet station may be under-representative of that area because of sheltering of the sensor by the nearby forest. Finally, it was surmised that of the three remaining wind stations, the data from the Eugene airport were believed to be most rigorously controlled for quality. As a result, wind speed and direction data from the Eugene airport station were used in the models. Wind speed was converted to metric units and wind direction was converted to radians for the model, where 0 radians means wind from the north. The wind speed measurement height (CE-QUAL-W2 parameter WINDH) was set to $10 \mathrm{~m}$.

Cloud-cover data were obtained from the weather station at the Eugene airport. The coding used for cloud cover data by NCDC (National Oceanic and Atmospheric Administration, 1998) was converted from text to the numeric (1-10) format required for CE-QUAL-W2 input similar to U.S. Environmental Protection Agency (1997) methods as follows: "CLR" $=0$, "FEW" $=1.5$, "SCT"=3.8, "BKN"=6.9, "POB"=8, "OBS"=9, "OVC" $=10.0, " * * * "=\mathrm{NA}$ (where NA is missing data).

Solar radiation data were retrieved from the SRML (University of Oregon, 2012). Global radiation values were used (the sum of direct, diffuse, and ground-reflected values), and converted from Langleys per hour to watts per square meter.

Precipitation data were available from USACE at HCWO and LPWO for 2006, 2008, and 2011. Precipitation data were available from Agrimet Station CRVO in Corvallis, Oregon, for 2002 (fig. 1). Precipitation temperature was estimated to be equal to air temperature.

\section{Hydrologic Data}

Measured streamflow and temperature data were used when available, but many input datasets had to be estimated (table 3). The three primary sources of data were the USGS National Water Information System (U.S. Geological Survey, 2012b), the USACE Dataquery Web site (U.S. Army Corps of Engineers, 2012a), and the ODEQ Laboratory Analytical Storage and Retrieval (LASAR) database (Oregon Department of Environmental Quality, 2011a). 
Table 3. Streamflow and water-temperature data sources for the flow and temperature models, Oregon.

[Shaded rows indicate model connection nodes. Abbreviations: USGS, U.S. Geological Survey; E: estimated, M: measured;]

\begin{tabular}{|c|c|c|c|c|c|c|c|c|c|c|}
\hline \multirow{2}{*}{$\begin{array}{c}\text { Model } \\
\text { Inflow/Outflow } \\
\text { Location }\end{array}$} & \multirow[b]{2}{*}{ Station name } & \multirow[b]{2}{*}{ USGS ID } & \multicolumn{2}{|c|}{2002} & \multicolumn{2}{|c|}{2006} & \multicolumn{2}{|c|}{2008} & \multicolumn{2}{|c|}{2011} \\
\hline & & & $Q$ & $T$ & Q & $T$ & Q & $\mathrm{T}$ & 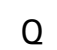 & $T$ \\
\hline HCL, Branch 1 & $\begin{array}{l}\text { MF Willamette R above } \\
\text { Hills Creek }\end{array}$ & 14144800 & $\mathrm{E}$ & $\mathrm{E}$ & $\mathrm{E}$ & $\mathrm{E}$ & $\mathrm{E}$ & $\mathrm{E}$ & $\mathrm{E}$ & M \\
\hline HCL, Branch 2 & Packard Creek & - & $\mathrm{E}$ & $\mathrm{E}$ & $\mathrm{E}$ & $\mathrm{E}$ & $\mathrm{E}$ & $\mathrm{E}$ & $\mathrm{E}$ & $\mathrm{E}$ \\
\hline HCL, Branch 3 & Larison Creek & - & $\mathrm{E}$ & E & $\mathrm{E}$ & $\mathrm{E}$ & $\mathrm{E}$ & $\mathrm{E}$ & $\mathrm{E}$ & $\mathrm{E}$ \\
\hline HCL, Branch 4 & Hills Creek & 14144900 & $\mathrm{E}$ & $\mathrm{E}$ & $\mathrm{E}$ & $\mathrm{E}$ & $\mathrm{E}$ & $\mathrm{E}$ & $\mathrm{E}$ & M \\
\hline $\begin{array}{l}\text { MFWR, Segment } \\
11\end{array}$ & $\begin{array}{l}\text { MF Willamette R above } \\
\text { Salt Creek near Oakridge }\end{array}$ & 14145500 & M & $\mathrm{M}^{1}$ & $\mathrm{M}$ & & M & & $\mathrm{M}$ & $\mathrm{M}$ \\
\hline $\begin{array}{l}\text { MFWR, Segment } \\
14\end{array}$ & Salt Creek & 14146000 & $\mathrm{E}$ & E & $\mathrm{E}$ & $\mathrm{E}$ & $\mathrm{E}$ & $\mathrm{E}$ & $\mathrm{E}$ & $\mathrm{E}$ \\
\hline $\begin{array}{l}\text { MFWR, Segment } \\
27\end{array}$ & Salmon Creek & 14146500 & $\mathrm{E}$ & E & $\mathrm{E}$ & $\mathrm{E}$ & $\mathrm{E}$ & $\mathrm{E}$ & $\mathrm{E}$ & $\mathrm{E}$ \\
\hline $\begin{array}{l}\text { MFWR, Segment } \\
70\end{array}$ & $\begin{array}{l}\text { North Fork of Middle } \\
\text { Fork Willamette River }\end{array}$ & 14147500 & $\mathrm{E}$ & E & $\mathrm{E}$ & $\mathrm{E}$ & $\mathrm{E}$ & $\mathrm{E}$ & $\mathrm{E}$ & $\mathrm{M}$ \\
\hline LOP, Branch 1 & $\begin{array}{l}\text { MF Willamette R blw } \\
\text { NFMFW }\end{array}$ & 14148000 & M & & $\mathrm{M}$ & & M & & M & $\mathrm{M}$ \\
\hline $\begin{array}{l}2.4 \text { Miles } \\
\text { downstream of } \\
\text { DEX }\end{array}$ & $\begin{array}{l}\text { MF Willamette R blw } \\
\text { Dexter }\end{array}$ & 14150000 & M & M & M & M & M & M & $\mathrm{M}$ & M \\
\hline
\end{tabular}

${ }^{1}$ Partial year of data existed from the Oregon Department of Environmental Quality.

For the Hills Creek Lake model, measured streamflow data were not available for the Middle Fork Willamette River near Oakridge (USGS station 14144800) and Hills Creek upstream of Hills Creek Lake (USGS station 14144900) after 1997 and 1981, respectively. However, streamflow data were collected at the two stations for 40 and 24 years, respectively, providing adequate data to perform a regression analysis with nearby USGS stations and the USACEcomputed inflow into Hills Creek Lake. A forward stepwise regression was created to estimate streamflows for the study period at stations 14144800 and 14144900 .

Streamflow was estimated for Larrison Creek using a logarithmic regression analysis with data from Hills Creek. Because no streamflow data were available for Larrison Creek, the 95th percentile of streamflow exceedance, median streamflow, and 2-year flood were estimated using Streamstats (U.S. Geological Survey, 2012a) for both creeks. The logarithmic regression model then was run using those three points. Packard Creek streamflow was estimated in the same manner, also using Hills Creek as an index.

The reach of the Middle Fork Willamette River between Hills Creek Dam and Lookout Point Lake is about $13.8 \mathrm{mi}$ in length. Three significant tributaries join the MFWR along this stretch-Salt Creek (USGS station 14146000), Salmon Creek (USGS station 14146500) and the 
North Fork of the Middle Fork of the Willamette River (USGS station 14147500) (fig. 2). All three tributaries have been gaged by USGS in the past. Tributary inflows for modeled calendar years without gage data were estimated using multiple linear regressions with regional gaged streams. When possible, regional gaged streams that represented similar climatological and topographical conditions were selected. Additionally, streamgages were selected that had the most overlap of record, and that surrounded the Middle Fork Willamette River in all directions so as to minimize any bias from the movement of weather patterns. Streamflow data for the upper end of this reach of the MFWR was taken from USGS station 14145500 (fig. 2). At the end of the reach upstream of Lookout Point Lake, streamflow calculations were compared with data from USGS station 14148000. Both stations were in operation throughout the 4 calendar years modeled for this study.

For the Lookout Point and Dexter Lakes model, USGS streamflow data were available as both inputs (station 14148000) and outputs (14150000) for all 4 calendar years modeled (fig. 2). Hourly release rates from the various outlets of HCL, LOP, and DEX were obtained from USACE and were used as outflow boundary conditions to the models. Forebay water-surface elevations were measured by USACE at HCL, LOP, and DEX, and those data were compared to modeled elevations during the water-balance calibration.
Inflow Water Temperature

Measured upstream boundary condition temperature data were available in 2011 for the HCL model (USGS stations 14144800 and 14144900), the MFWR model (1USGS station 4145500), and the LOP-DEX model (USGS station 14148000) (table 3). Additionally, measured temperature data were available in 2011 for the largest tributary in the MFWR model (NFMFWR, 14147500).

All other inflowing temperature boundary conditions to the models were approximated using a nonlinear multiple loess regression $(\mathrm{R}$ Development Core Team, 2009). Stream temperatures measured by ODEQ during the summer of 2002 (June 1-September 9) were used to develop these regression models for Salt Creek, Hills Creek (USGS 14144900; ODEQ 27982), and MFWR (USGS 14144800; ODEQ 27986) based on measured temperatures at other USGS sites in the Willamette River Basin (table 4). The regression model for the NFMFW (USGS 14147500) was based on calendar year (CY) 2011 measured data and resulted in an accurate stream temperature estimate (fig. 5, table 4). Salt Creek temperature estimates were used as inflow temperatures for Larrison and Packard Creeks (branches 2 and 3 of the Hills Creek Lake model). Similarly, the data from the NFMFWR were used as the inflow temperatures for Salmon Creek (tributary 2 in the MFWR model).

Table 4. Inflow-temperature estimation regression information and fit statistics.

[Abbreviations: sfmck, South Fork McKenzie River (14159200); nsbld, North Santiam River at Boulder (14178000); blwcr, Blowout Creek (14180300) ; USGS, U.S. Geological Survey; ODEQ, Oregon Department of Environmental Resources-, no USGS site ID].

\begin{tabular}{|c|c|c|c|c|c|c|c|c|}
\hline \multirow{2}{*}{$\begin{array}{l}\text { Model inflow } \\
\text { location }\end{array}$} & \multirow{2}{*}{$\begin{array}{c}\text { Model inflow } \\
\text { temperature estimate }\end{array}$} & \multicolumn{2}{|c|}{ Site ID } & \multirow[b]{2}{*}{ Year } & \multirow{2}{*}{$\begin{array}{l}\text { Dependent } \\
\text { variables }\end{array}$} & \multicolumn{3}{|c|}{ Goodness of fit statistics } \\
\hline & & USGS & ODEQ & & & MAE & ME & RMSE \\
\hline HCL, Branch 1 & $\begin{array}{c}\text { MF Willamette R above } \\
\text { Hills Creek }\end{array}$ & 14144800 & 27986 & 2002 & $\begin{array}{l}\text { sfmck, nsbld, } \\
\text { blwcr }\end{array}$ & 0.35 & 0 & 0.45 \\
\hline HCL, Branch 2 & Hills Creek & 14144900 & 27982 & 2002 & $\begin{array}{l}\text { sfmck, nsbld, } \\
\text { blwcr }\end{array}$ & 0.57 & 0.01 & 0.79 \\
\hline MFWR, Segment 70 & $\begin{array}{l}\text { North Fork of Middle } \\
\text { Fork Willamette River }\end{array}$ & 14147500 & 28003 & 2011 & $\begin{array}{l}\text { sfmck, nsbld, } \\
\text { blwcr }\end{array}$ & 0.44 & -0.02 & 0.55 \\
\hline MFWR, Segment 14 & Salt Creek & - & 28007 & 2002 & sfmck, blwcr & 0.38 & 0 & 0.48 \\
\hline
\end{tabular}




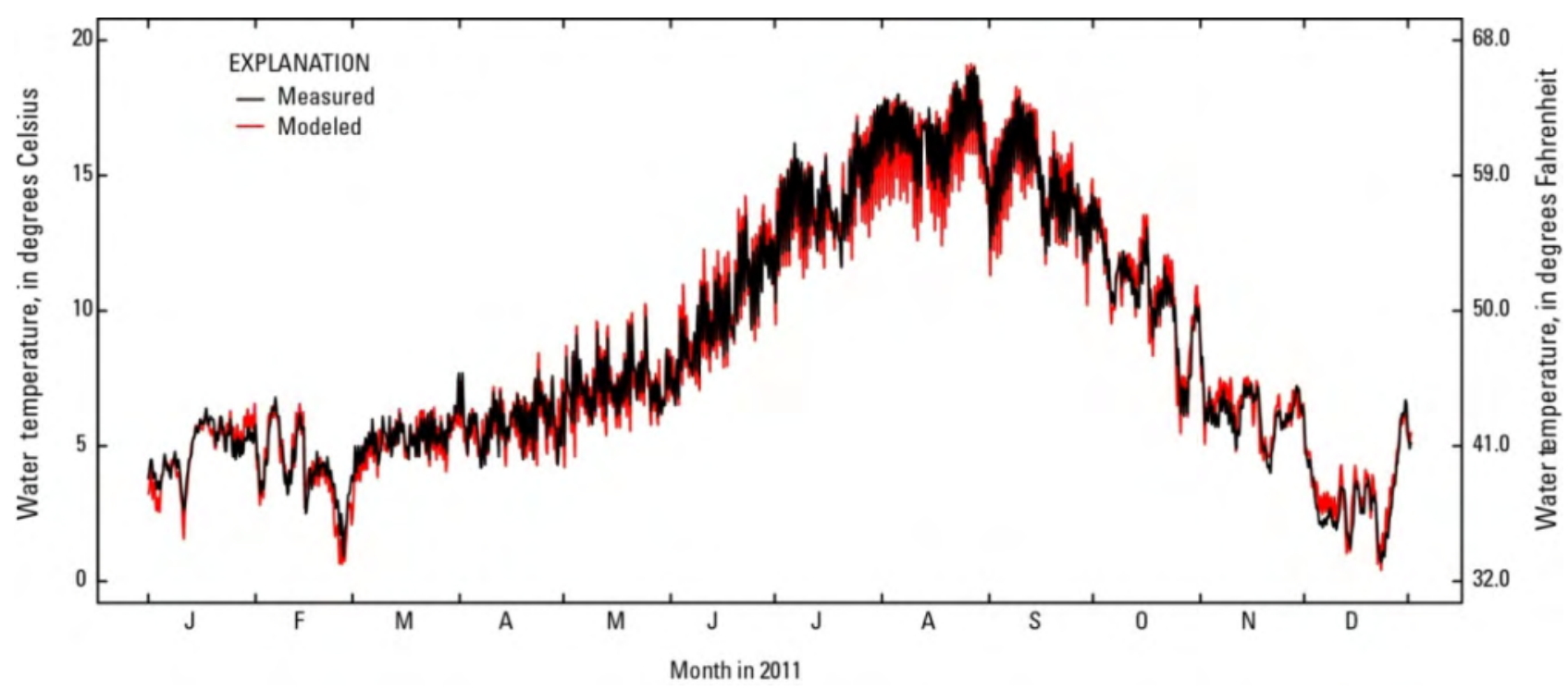

Figure 5. Graph showing estimated and measured temperature at U.S. Geological Survey stream-gaging station 14144800, North Fork of Middle Fork Willamette River, Oregon.

\section{Lake Profile Data and Outflow Water Temperature}

Vertical lake profile data for two locations at HCL, one location at LOP, and two locations at DEX were provided by USACE for 2002 and 2011. Profile data were collected near the dam in all three reservoirs for both years. In 2002, instantaneous temperature profile measurements were made once or twice a month from late spring to late summer. Additional profiles at HCL (2002 only) and DEX (2002 and 2011) were collected farther upstream of the dam, and were labeled as "Mid-Lake". This location was estimated to coincide with segments 20 and 48 in the HCL and DEX models, respectively. In 2011, profile data were collected in 15-minute intervals by USACE from DEX from late April to late October, and from HCL and LOP from the start of 2011 through late November.

Hourly temperature data were available downstream of HCL at USGS station 14145500 during the summer 2002 and all of 2011. Downstream of DEX at USGS station 14150000, hourly temperature data were available in 2002 , 2006, 2008, and 2011.

\section{HCL Model Development and Calibration}

\section{Water Balance}

Prior to the calibration of temperature, the Hills Creek Lake (HCL) model was calibrated to simulate the lake water-surface elevation for each of the 4 years: 2002, 2006, 2008, and 2011. Lake elevation can have a substantial effect on the accuracy of the simulated temperatures. The process of closing the water balance for the lake minimizes the error owing to differences between measured and modeled lake elevation. To match modeled water-surface elevations with measured lake elevations (fig. 6), a distributed tributary inflow time series (QDT) was iteratively developed for each year by converting the daily average difference between measured and modeled lake elevation into a daily inflow (or loss) to the model. Distributed tributary streamflows are created to account for small, unmodeled tributaries and gains and losses from groundwater interaction or dam leakage. The percentage of QDT inflow compared to total inflow to the model varied for each calendar year, but median values ranged from 1.0 (2002) to 9.2 percent (2011). Similarly, 90th-percentile values ranged from 12.7 (2006) to 19.5 percent (2011). 

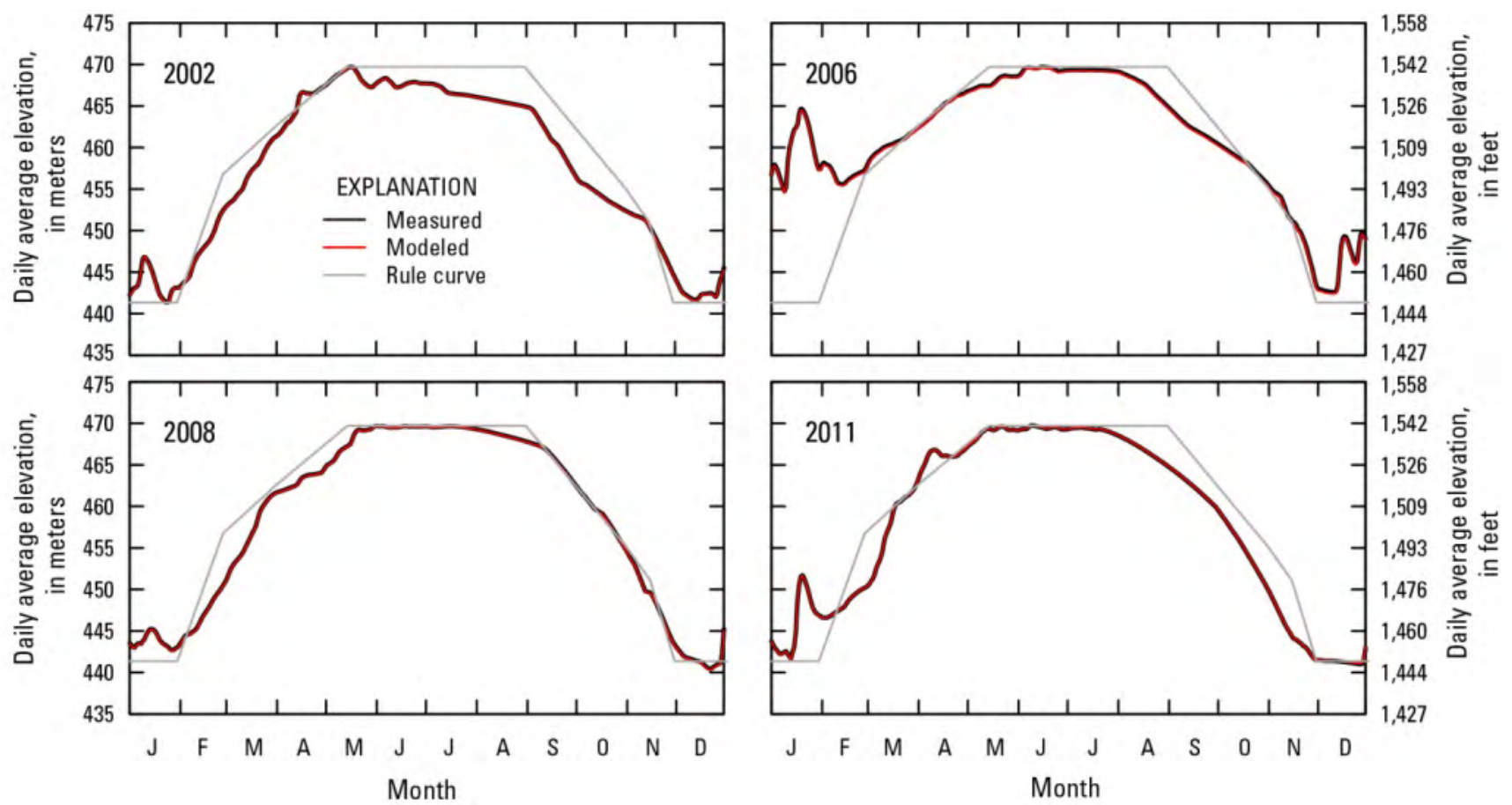

Figure 6. Graphs showing final water balance for Hills Creek Lake, Oregon, 2002, 2006, 2008, 2011, showing measured and modeled water-surface elevations along with the operational rule curve for the lake. 


\section{Water Temperature}

Hills Creek Dam has two radial tainter spillway gates that are only used in emergencies, two regulating outlets (ROs), and two power outlets (U.S. Army Corps of Engineers, 2009). The Hills Creek Lake model originally was configured with two structures at elevations of 455.5 and $442 \mathrm{~m}$ (West Consultants, Inc., 2004a).
In this study, the structure elevations were reset to the centerline structure elevations (433.0 and $425.0 \mathrm{~m}$ ) gathered from USACE documentation for Hills Creek Dam (U.S. Army Corps of Engineers, 2009; Kathryn Tackley, U.S. Army Corps of Engineers, oral commun., 2012) (fig. 7).
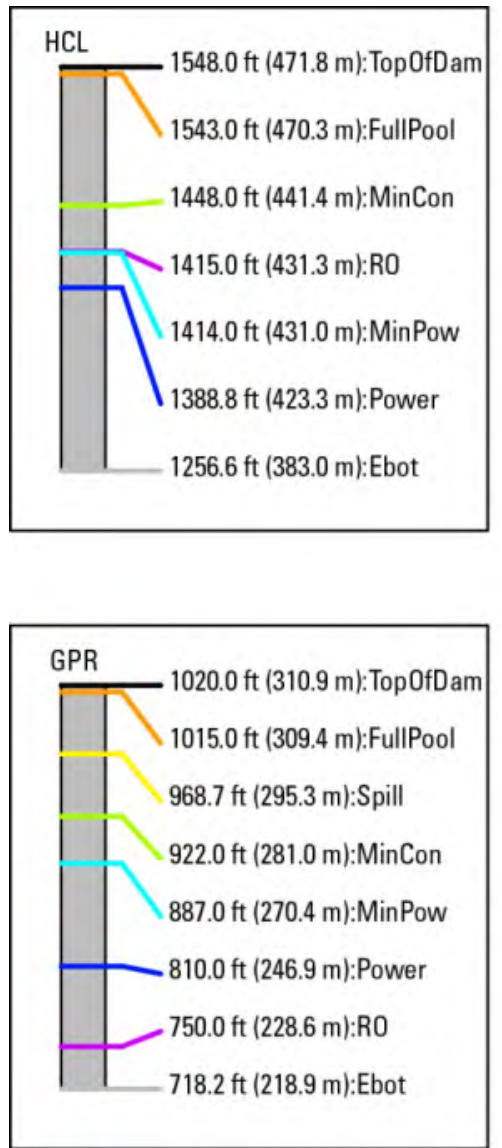
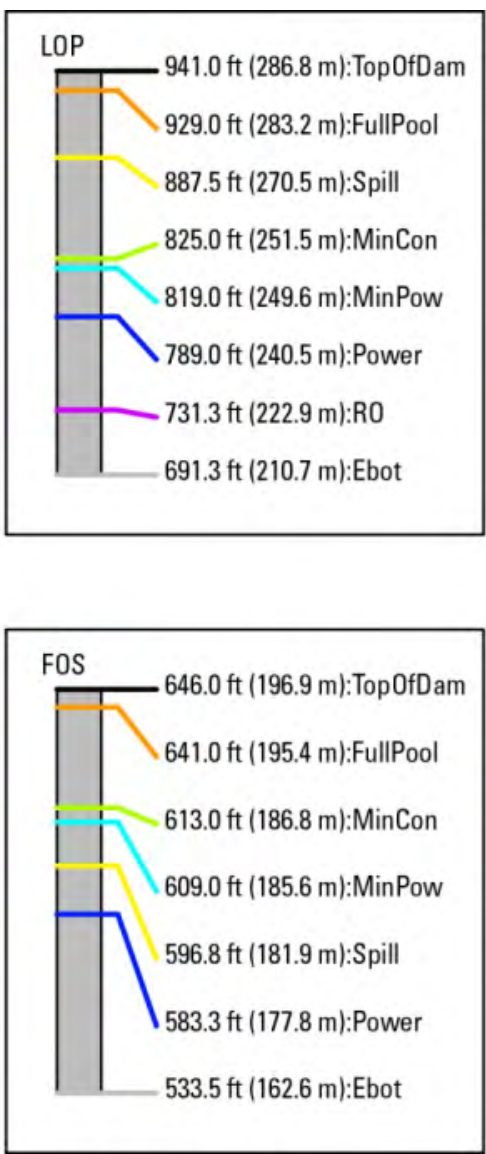

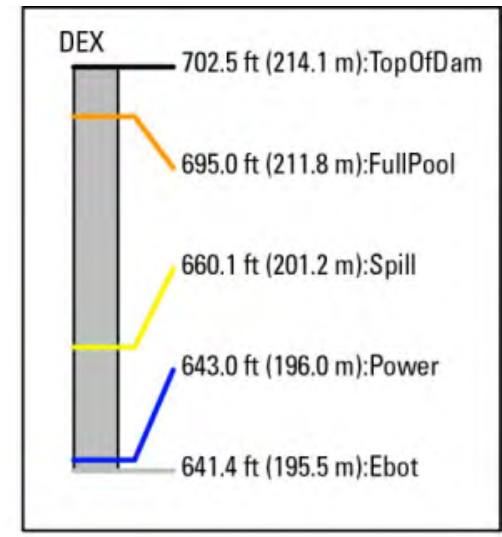

EXPLANATION

TopOfDam = Top of dam FullPool = Full pool Spill = Spillway elevation MinCon = Minimum conservation poo MinPow $=$ Minimum power pool Power $=$ Power intake centerline

- $\mathrm{RO}=$ Regulating outlet centerline - Ebot $=$ Bottom of model grid

Figure 7. Diagrams showing elevations of operational goals and structures for Hills Creek, Lookout Point, Dexter, Green Peter, and Foster Dams, Oregon. Elevations are relative to the National Geodetic Vertical Datum of 1929 (NGVD 29) (U.S. Army Corps of Engineers, 2009).

Because Hills Creek Dam does not have outlets near the bottom of the reservoir, there is little opportunity to release deeper water during the winter when lake elevations are lower. This leads to a long theoretical retention time $(0.5-2.0$ years) and a greater tendency for turbid water to remain at depth through the summer compared to the downstream Lookout Point Lake (Larson,
2001). Additionally, the ROs and the power penstocks at HCL are at similar depths and are the only outlets used, causing the thermocline to be situated near these outlet structures in late summer and early autumn. The strong influence of Hills Creek Dam outlet structures and releases on the circulation and vertical thermal structure in the lake led to a model that was highly sensitive 
to outlet structure parameters. In this study, the model parameters STR TOP and STR BOT (representing the upper and lower layer [depth] limits from which water is allowed to flow through model outflow structures) were varied to calibrate the HCL model with respect to outflow temperatures and profile temperatures near the dam. Changes that were made to the original West Consultants HCL model relating to outlet structure parameters are summarized in table 5 .

Table 5. Differences between outlet structure characteristics in original and updated model for Hills Creek Lake, Oregon.

[Abbreviations: STR, structure; RO, regulating outlet; Power, power penstock outlet; m, meter; USGS, U.S. Geological Survey]

\begin{tabular}{|c|c|c|c|c|c|}
\hline \multirow[b]{2}{*}{ Parameter } & \multicolumn{2}{|c|}{ West Consultants model } & \multicolumn{2}{|c|}{ USGS model } & \multirow[b]{2}{*}{ Description } \\
\hline & $\begin{array}{c}\text { STR 1 } \\
\text { (Power) }\end{array}$ & $\begin{array}{l}\text { STR } 2 \\
\text { (RO) }\end{array}$ & $\begin{array}{l}\text { STR } 1 \\
\text { (RO) }\end{array}$ & $\begin{array}{c}\text { STR 2 } \\
\text { (Power) }\end{array}$ & \\
\hline STR TOP & 2 & 2 & 10 & 10 & Structure top selective withdrawal limit \\
\hline STR BOT & 69 & 69 & 89 & 99 & Structure bottom selective withdrawal limit \\
\hline STR SINK & POINT & LINE & LINE & LINE & $\begin{array}{l}\text { Sink type used in the selective withdrawal } \\
\text { algorithm }\end{array}$ \\
\hline STR ELEV & 442.0 & 455.5 & 431.3 & 423.3 & Centerline elevation of structure, $m$ \\
\hline STR WIDTH & - & 38.4 & 6.0 & 5.8 & Width of structure (line sink), $m$ \\
\hline
\end{tabular}

The Hills Creek Lake model distributed tributary flow estimates (QDT) were accompanied by distributed tributary temperature estimates (TDT). The TDT was estimated as follows:

$T D T=0.9 T_{a}+0.1 T_{s}$

where

$T_{a}=$ average annual air temperature measured at Hills Creek Lake, and

$T_{S}=$ estimated Salt Creek temperature, both in degrees Celsius.

Groundwater temperatures tend to be well represented in many areas by an annual average air temperature $\left(\mathrm{T}_{\mathrm{a}}\right)$. Modeled temperatures near the bottom of Hills Creek Lake were sensitive to the TDT values, and tended to fit measured temperatures better when the TDT was assumed to be relatively constant and near an assumed groundwater temperature for the area.
Instantaneous temperature profiles measured by USACE in 2002 near Hills Creek Dam and at the "mid-lake" locations were well matched by the HCL model, except for some errors near the lake surface (fig. 8). Continuous profiles in 2011, also measured by USACE, were matched well by the model, especially in the epilimnion (depths less than $39.4 \mathrm{ft}$ [12.0 m] in fig. 9). During JulyNovember, 2011, the HCL model tended to overpredict temperatures between depths of $12 \mathrm{~m}$ $(39.4 \mathrm{ft})$ and $43 \mathrm{~m}(141 \mathrm{ft})$. The bathymetry of the lake near the dam is complex, and circulation near the Hills Creek arm of the lake may be affecting the ability of the model to capture some of these seasonal temperature patterns near the depth of the outlets. Accurately capturing the thermal structure in the lake was somewhat of a compromise against accurately simulating the release temperatures; improvements in one often led to degradation of the other. Model performance, however, was deemed acceptable, as the downstream release temperatures were matched with good accuracy. 

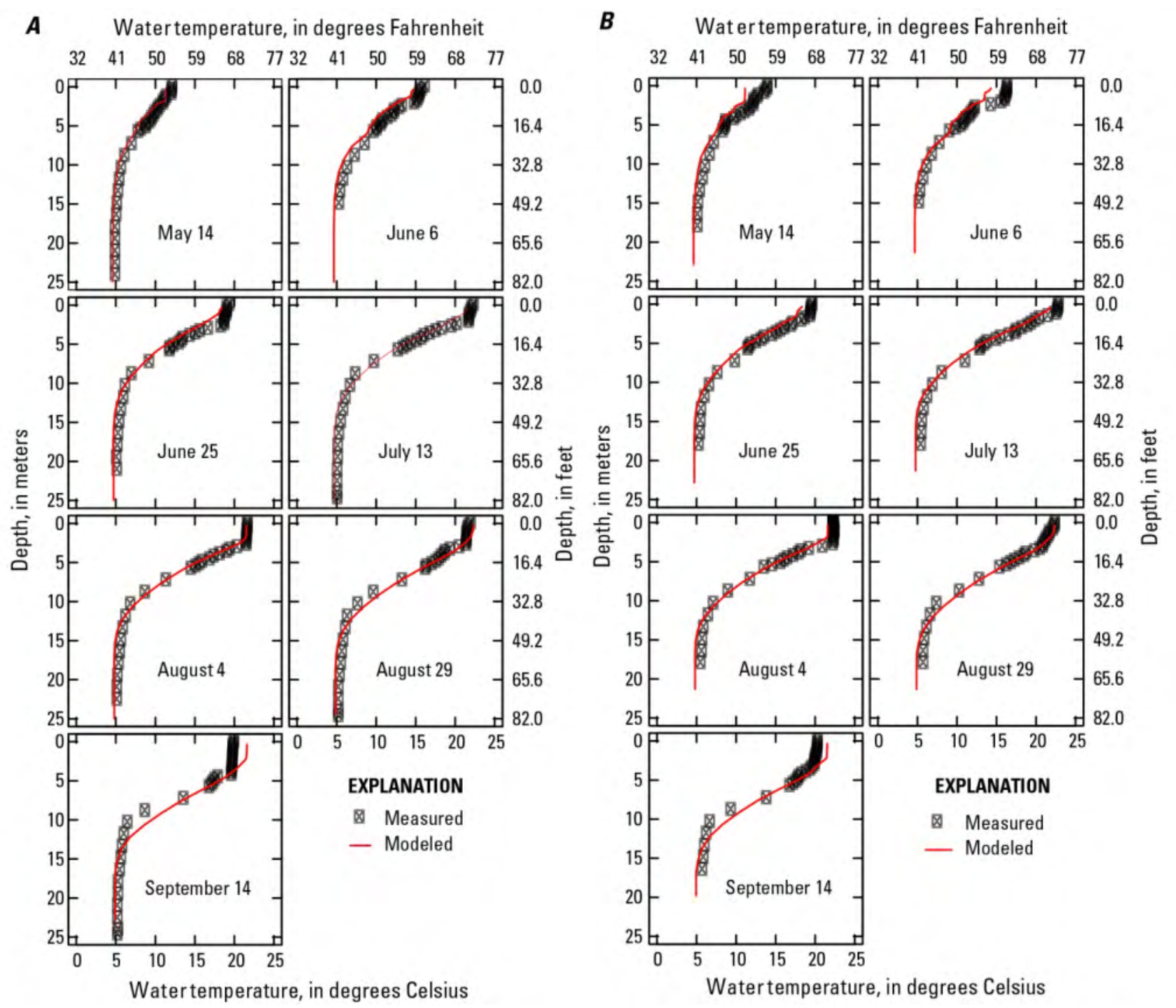

Figure 8. Graphs showing measured and modeled vertical temperature profiles in Hills Creek Lake, Oregon, 2002. (A) near the dam, and (B) near a mid-lake location. 


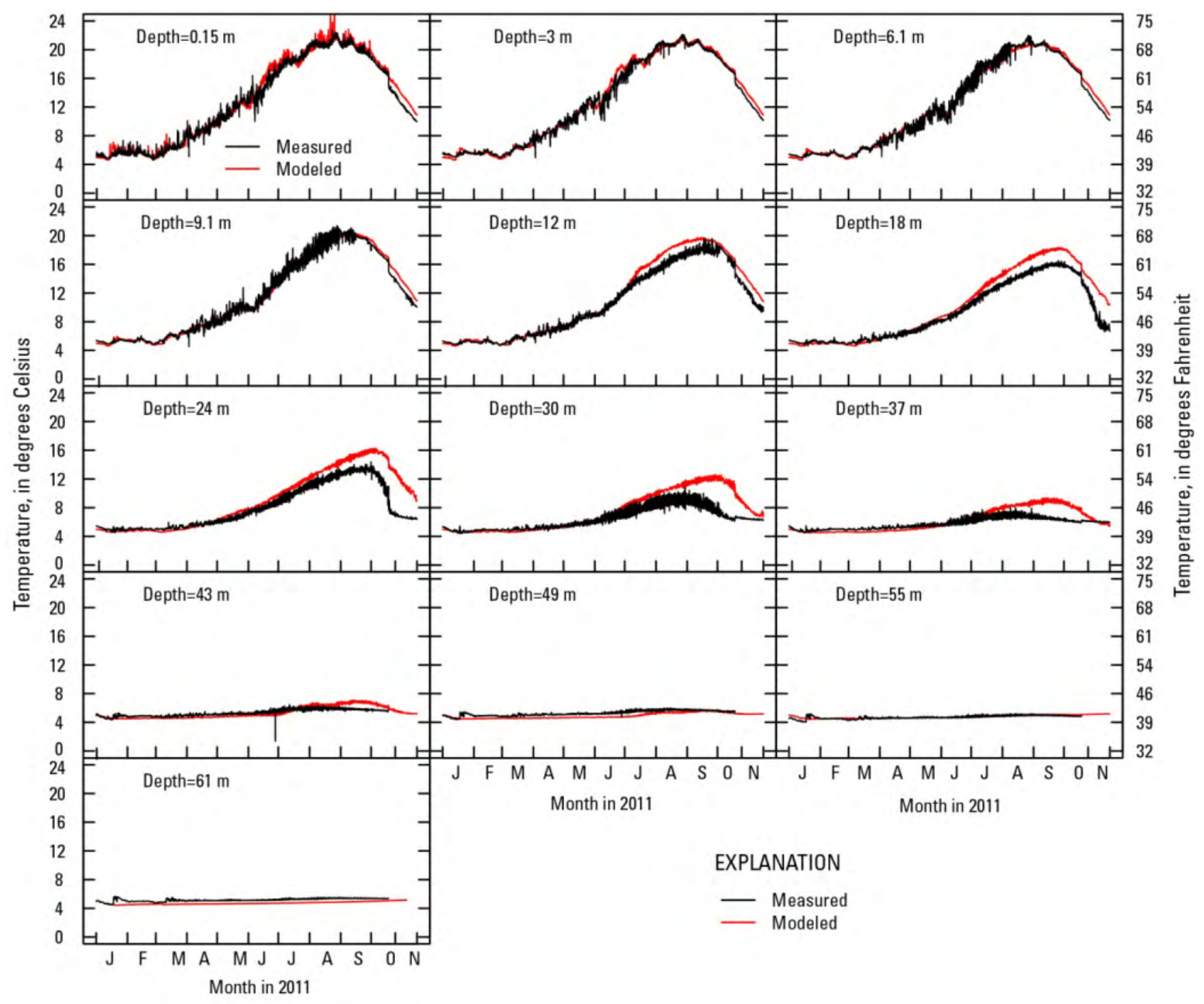

Figure 9. Graphs showing measured and modeled water temperatures at specific depths in Hills Creek Lake near the dam, Oregon, 2011.

Measured temperatures in the Middle Fork Willamette River downstream of Hills Creek Dam at USGS site 14145500 were available from Oregon Department of Environmental Quality (2011a) for the summer of 2002 (June 1September 9) and for all of 2011 from U.S. Geological Survey (2012b) for model outflow temperature calibration. Modeled outflow temperatures from HCL were slightly low (mean error [ME] of $-0.52^{\circ} \mathrm{C}$ ) compared to measured values in 2002 (table 6 and fig. 10). In 2011, HCL model outflow temperatures matched closely for the majority of the year $(\mathrm{ME}=$ $0.03^{\circ} \mathrm{C}$, mean absolute error $[\mathrm{MAE}]=0.50^{\circ} \mathrm{C}$ ) despite some over-predictions during the November and December drawdown period (fig. 10). 

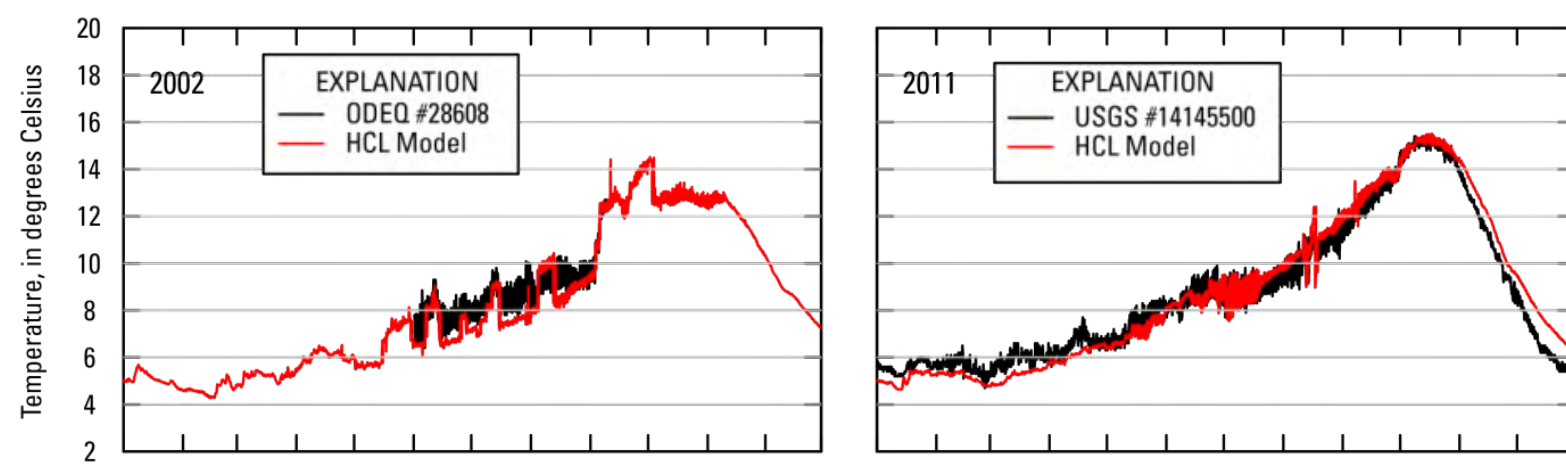

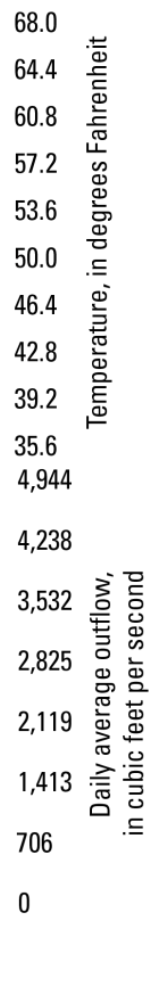
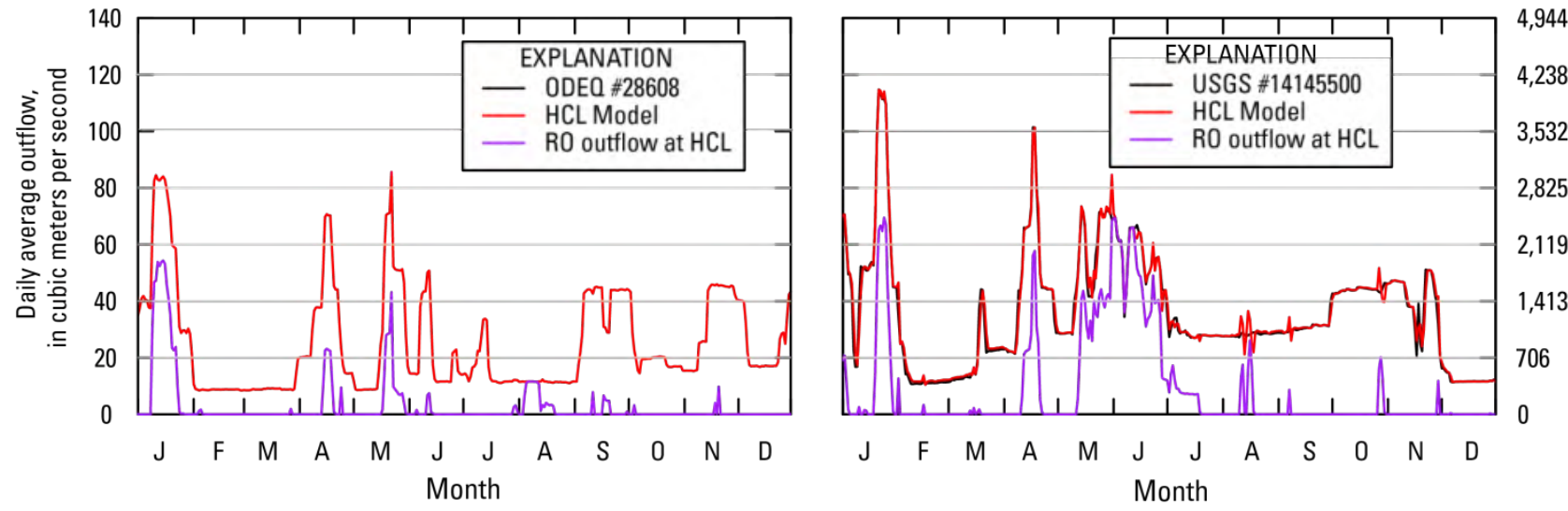

Figure 10. Graphs showing measured and modeled outflow temperatures and release rates from Hills Creek Lake (HCL), Oregon, 2002 and 2011. Releases were through the power penstocks and the regulating outlet (RO). 
Table 6. Goodness-of-fit statistics comparing measured and modeled water temperatures for the Hills Creek Lake, Middle Fork Willamette River, and Lookout Point-Dexter Lakes models, Oregon.

[Goodness-of-fit statistics are in degrees Celsius. Abbreviations: DEX, Dexter Lake; HCL, Hills Creek Lake; LOP, Lookout Point Lake; ME, mean error, MAE, mean absolute error; MFWR, Middle Fork Willamette River; RMSE, root mean square error; Q, flow; T, water temperature; USGS, U.S., Geological Survey]

\begin{tabular}{|c|c|c|c|c|c|c|c|}
\hline Model & $\begin{array}{l}\text { Upstream } \\
\text { Boundary }\end{array}$ & $\begin{array}{c}\text { Type of } \\
\text { Measurement } \\
\text { Data } \\
\end{array}$ & Year & $\begin{array}{c}\text { Number of } \\
\text { Observations }\end{array}$ & ME & MAE & RMSE \\
\hline \multirow{4}{*}{ HCL } & \multirow{4}{*}{ Measured Q, T } & \multirow{2}{*}{ Outflow } & 2002 & 2,401 & -0.52 & 0.68 & 0.82 \\
\hline & & & 2011 & 8,735 & 0.03 & 0.50 & 0.61 \\
\hline & & $\begin{array}{l}\text { Near-dam } \\
\text { depth profiles }\end{array}$ & 2002 & 215 & -0.54 & 0.86 & 1.09 \\
\hline & & $\begin{array}{l}\text { Thermistor } \\
\text { string }\end{array}$ & 2011 & 96,020 & 0.30 & 0.65 & 1.04 \\
\hline \multirow{4}{*}{$\begin{array}{l}\text { MFWR at USGS } \\
14148000\end{array}$} & \multirow{3}{*}{$\begin{array}{l}\text { HCL } \\
\text { Modeled Q, T }\end{array}$} & \multirow{3}{*}{ Outflow } & 2002 & 2,688 & -0.49 & 0.75 & 0.96 \\
\hline & & & 2008 & 2,242 & 0.40 & 0.61 & 0.76 \\
\hline & & & 2011 & 34,934 & -0.01 & 0.49 & 0.62 \\
\hline & Measured Q, T & Outflow & 2011 & 34,934 & -0.06 & 0.53 & 0.66 \\
\hline \multirow{2}{*}{ LOP } & \multirow{2}{*}{ Measured Q, T } & $\begin{array}{l}\text { Near-dam } \\
\text { depth profiles }\end{array}$ & 2002 & 216 & -0.58 & 0.74 & 0.99 \\
\hline & & $\begin{array}{l}\text { Thermistor } \\
\text { string }\end{array}$ & 2011 & 91,848 & 0.17 & 0.54 & 0.77 \\
\hline \multirow{7}{*}{ DEX } & $\begin{array}{l}\text { Measured Q; } \\
\text { MFWR } \\
\text { Modeled T }\end{array}$ & $\begin{array}{l}\text { Near-dam } \\
\text { depth profiles }\end{array}$ & 2002 & 65 & 0.00 & 0.72 & 0.93 \\
\hline & \multirow[t]{2}{*}{ Measured Q, T } & $\begin{array}{l}\text { Thermistor } \\
\text { string }\end{array}$ & 2011 & 34,952 & 0.34 & 0.83 & 1.08 \\
\hline & & Outflow & 2011 & 8,731 & -0.15 & 0.44 & 0.55 \\
\hline & \multirow{4}{*}{$\begin{array}{l}\text { MFWR } \\
\text { Modeled Q, T }\end{array}$} & \multirow{4}{*}{ Outflow } & 2002 & 8,724 & -0.43 & 0.63 & 0.82 \\
\hline & & & 2006 & 8,731 & -0.17 & 0.55 & 0.69 \\
\hline & & & 2008 & 8,717 & 0.26 & 0.50 & 0.66 \\
\hline & & & 2011 & 8,731 & -0.16 & 0.49 & 0.60 \\
\hline
\end{tabular}

USGS temperature cross-sectional measurements taken at station $14145500(1.1 \mathrm{mi}$ downstream of Hills Creek Dam) show that the river at that site is well-mixed, with crosssectional variation typically less than or equal to $0.2^{\circ} \mathrm{C}$. The USGS temperature probe is located near the right bank (looking downstream), where most of the streamflow occurs. 


\section{MFWR Model Development and Calibration}

The Middle Fork Willamette River is relatively wide and shallow, with a mean width and depth of 50.4 and $1.5 \mathrm{~m}$, respectively. This river has a relatively steep bottom slope, resulting in high water velocities (average of $1 \mathrm{~m} / \mathrm{s}$ in 2011) and short travel times (average of 6 hours in 2011) through this 13.8-mi reach (fig. 4). With these topographic characteristics and resulting effects, water temperature generally was affected more by the inflows and outflows from the river model as boundary conditions rather than model parameters related to the hydrodynamics and heat budget. Shading coefficients for each segment of the MFWR model were set to 0.6.

\section{Water Balance}

Upstream inflows for the MFWR were tabulated from USGS station 14145500. Three significant tributaries were included in the model-Salt Creek, Salmon Creek, and the Middle Fork of the North Fork Willamette River (MFNFWR) (USGS stations 14146000, 14146500, and 14147500, respectively). Streamflow records for these three tributaries do not exist after 1994. Streamflow inputs were estimated for each tributary using a regression analysis from neighboring USGS stations on rivers of similar size.
Surface-water elevations simulated by the MFWR model were compared with measured gage height data at USGS station 14148000 (the station near the downstream end of the MFWR model; see fig. 2). The MFWR model was sensitive to adjustments in slope and bottom friction parameters (SLOPE, SLOPEC, and FRICT), owing partly to the relative steepness of the channel. The parameters of SLOPE and SLOPEC were set at $0.0042(\mathrm{~m} / \mathrm{m})$ and 0.0010 $(\mathrm{m} / \mathrm{m})$ respectively. The Manning's bottom friction type (FRICC) was selected and the bottom friction values (FRICT) were set to 0.06 along the length of the river, which is typical for a free-flowing river in the region (Barnes, 1967). The spillway option was selected in this river model as the outlet structure at the downstream end of the river system.

Without accounting for ungaged inflows, the resulting downstream streamflow from the MFWR model was consistently biased low compared to measured streamflow. To maintain a correct energy and water balance within the model, deficit streamflow was added to the river model using the distributed tributary flow input, resulting in a more accurate match to the measured streamflow at the downstream end of the model (fig. 11). 

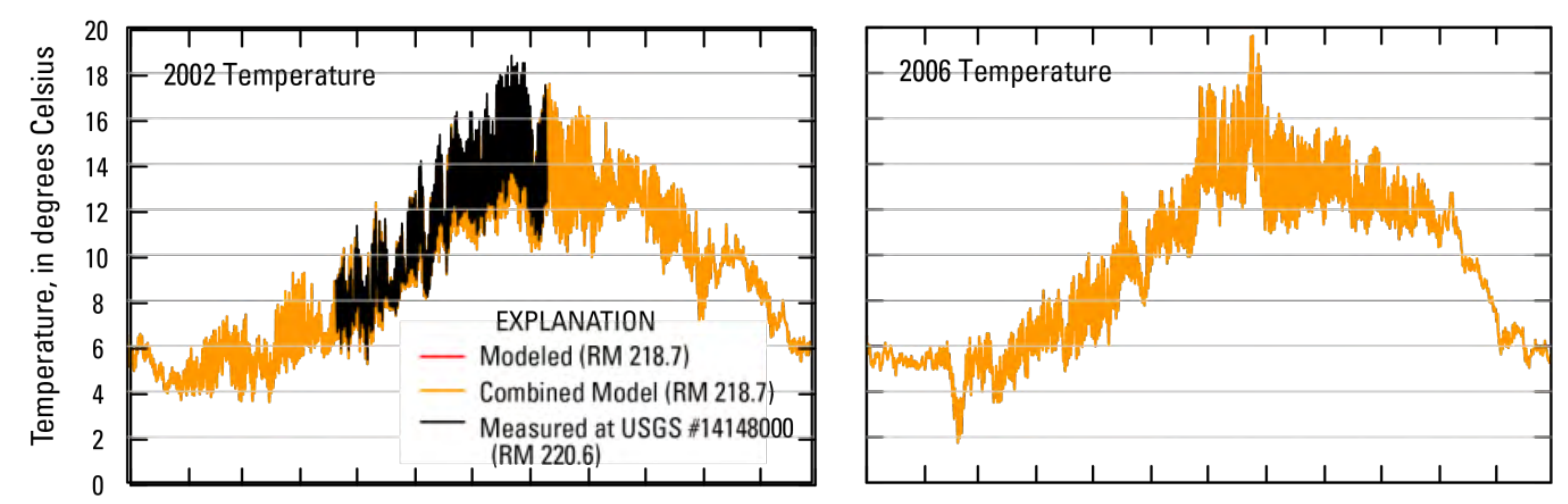

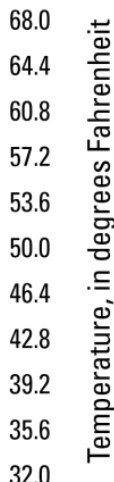
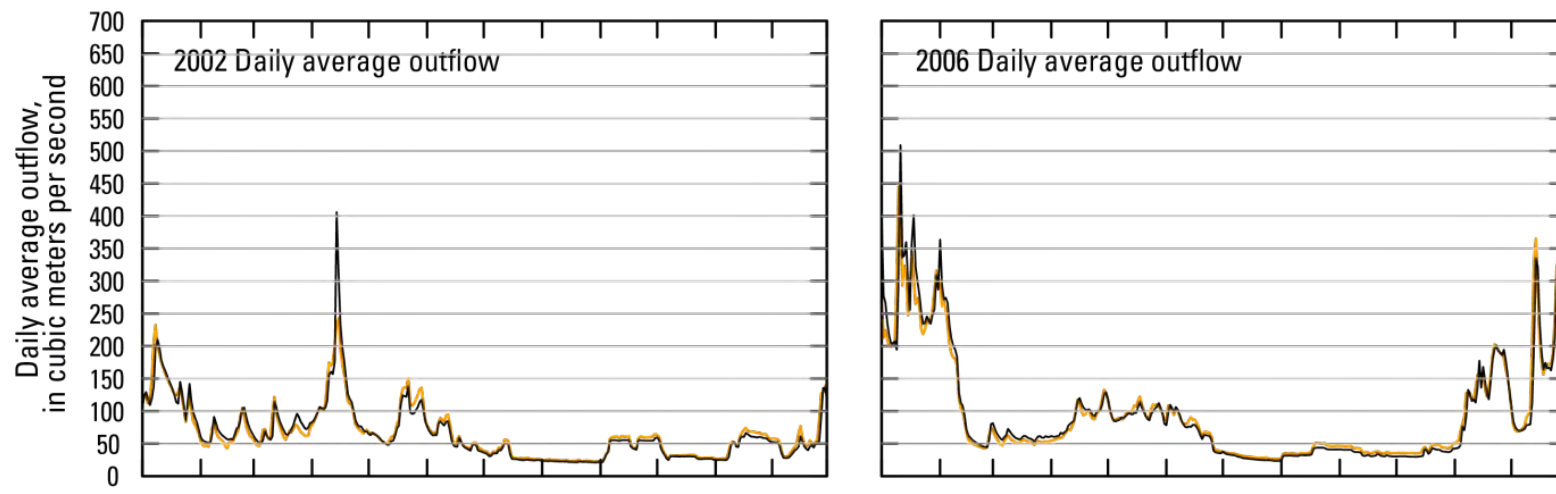

24,720

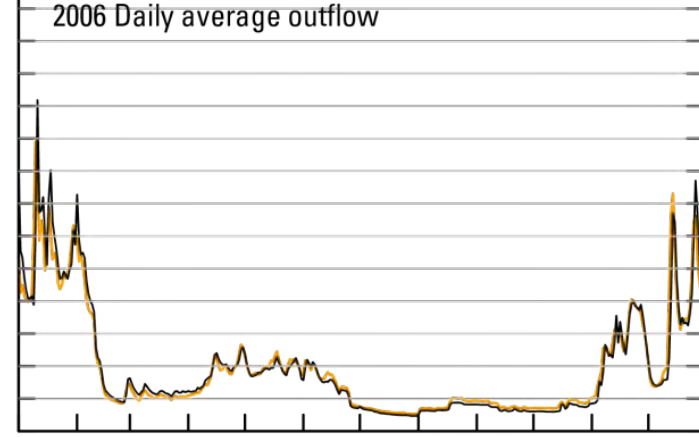

21,189

19,423

17,657

15,892

14,126

12,360

10,594

8,829

7,063

5,297

3,532
1,766

1,766
0
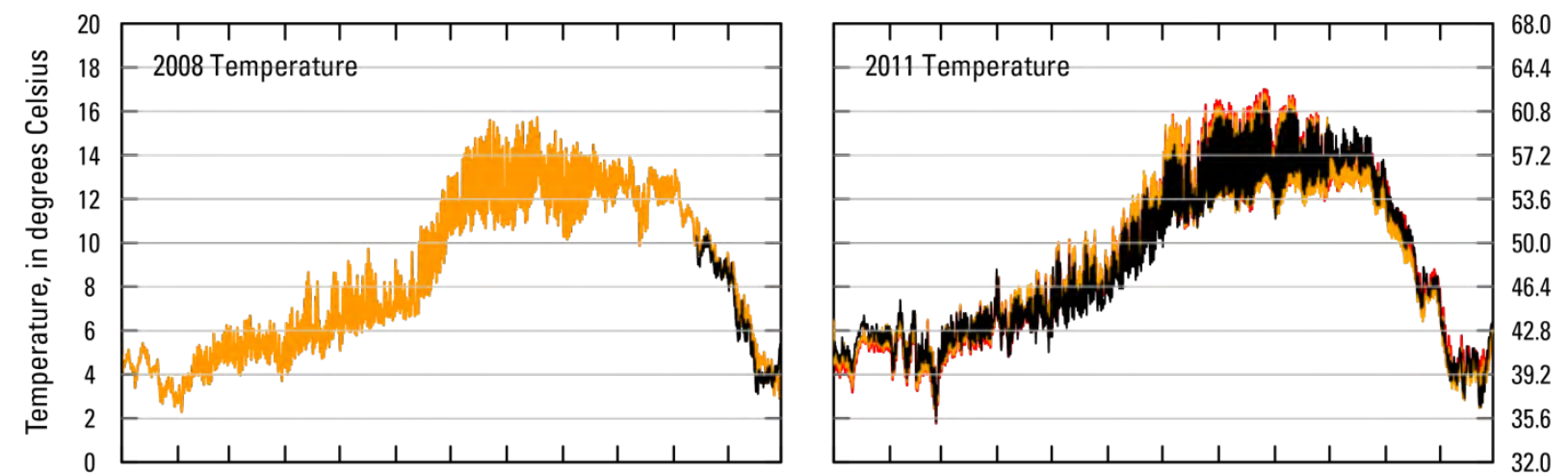

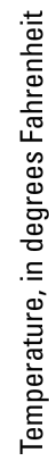
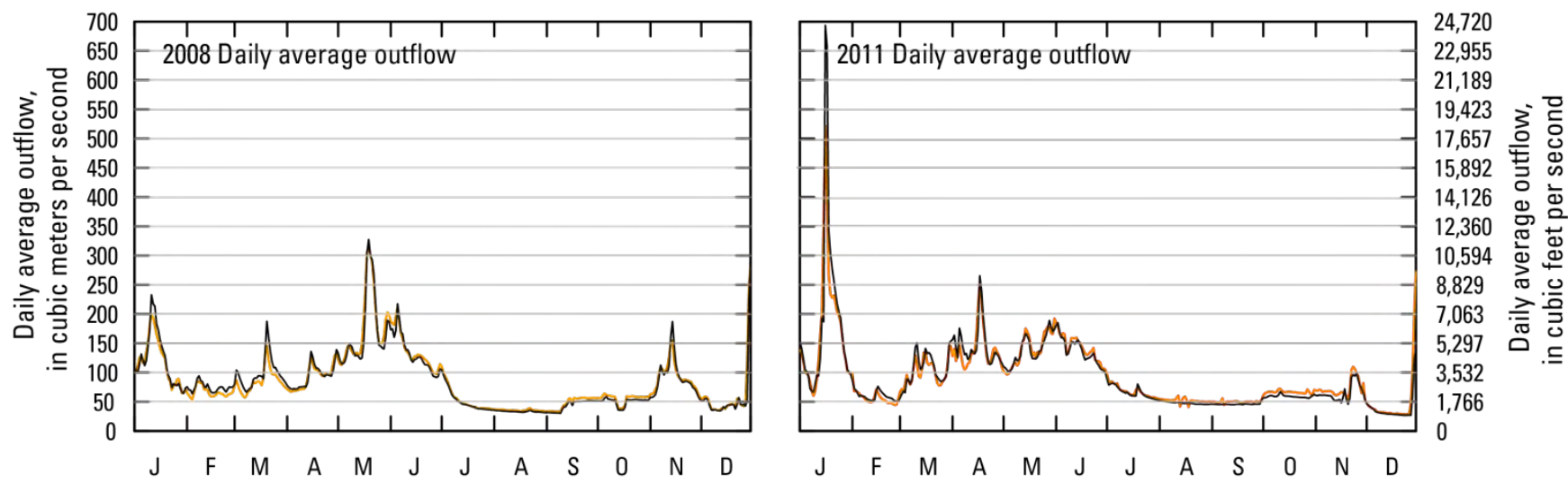

Figure 11. Graphs showing model outflow and temperature for Middle Fork Willamette River and measured flows and temperatures at U.S. Geological Survey station 14148000, Oregon, 2002, 2006, 2008, and 2011. 
Although it would be possible to correct the model to match measured streamflow for each unit of time, such a procedure would not be reproducible for simulations with altered flow requirements, such as outflow from 2002 that incorporates more recent dam operation protocols. Additionally, although the simulated streamflow without added ungaged flows shows a clear negative bias, correcting the water balance for each individual time step would introduce a large degree of noise (variation). An alternate approach was developed to overcome these issues, in which the flow in the distributed tributary was set as follows:

$Q_{D T_{i}}=\frac{Q_{i}}{\sum_{i} Q_{i}}\left(\frac{\sum_{i} Q_{M E}-\sum_{i} Q_{M O}}{T_{i}}\right)$

where

$\mathrm{Q}_{\mathrm{DTi}}=$ Distributed tributary input for time step $i$, in cubic meters per second;

$\mathrm{Q}_{\mathrm{i}} \quad=$ Inflows for time step $\mathrm{i}$, in cubic meters per second;

$\sum_{i} Q_{M E}=$ Annual streamflow volume measured, in cubic meters;

$\sum_{i} Q_{M O}=$ Annual streamflow volume modeled, in cubic meters; and

$\mathrm{T}_{\mathrm{i}}=$ Length of time step $\mathrm{i}$, in seconds.

For each calendar year, the total amount of streamflow modeled was subtracted from the total amount of streamflow measured at the model downstream boundary, in cubic meters. For each time step, the total amount of streamflow input (without ungaged inflows) was calculated, and divided by the total streamflow input for the calendar year. This resulted in a time series of percentages. Each percentage was then multiplied by the initial calculation of the total annual streamflow measured minus the total annual streamflow modeled, and then divided by the interval time. The end result was a time series of streamflows that represented the total amount of deficit streamflow from the model, but was weighed based on the amount of streamflow entering the system.

\section{Water Temperature}

Temperature calibration of the MFWR model was particularly sensitive to the windsheltering coefficient and inflow temperature. Temperature inputs for Salmon Creek, which enters the MFWR between the entry locations of Salt Creek and NFMFWR, was initially estimated identically to the temperatures of Salt Creek, which is closer in size to Salmon Creek than NFMFWR. Better model results, however, were achieved by using estimated NFMFWR temperatures as the temperatures assigned to Salmon Creek. For the MFWR model, a windsheltering coefficient of 0.3 (identical to that used on the upstream Hills Creek Lake model) was applied for the entire calendar year. This implies that using only 30 percent of the wind speed measured at the Eugene airport NCDC weather station (used as wind-speed boundary conditions for the HCL, MFWR, and LOP-DEX models [table 2]) led to a better calibration of the MFWR model. The MFWR has riparian vegetation along its banks, which is consistent with a significant amount of wind sheltering.

Other model parameters that also affected temperature calibration included the maximum vertical eddy viscosity (AZMAX) and bottom friction coefficient (FRICC). Selected parameter values used for the temperature calibration of the MFWR model are given in table 7. Other parameters were obtained from CE-QUAL-W2 default values as described in the W2 User's Manual (Cole and Wells, 2011). 
Table 7. Selected model parameters used in the Hills Creek Lake, Middle Fork Willamette River, and Lookout Point-Dexter Lakes models, Oregon.

[Abbreviations: HCL, Hills Creek Lake, MFWR, Middle Fork Willamette River; LOP-DEX, Lookout Point-Dexter Lakes; ${ }^{\circ} \mathrm{C}$, degrees Celsius; $\mathrm{m}^{2} / \mathrm{s}$, square meters per second]

\begin{tabular}{lcccl}
\hline Parameter & HCL & MFWR & LOP-DEX & \multicolumn{1}{c}{ Description } \\
\hline WSC & 0.3 & 0.3 & 1.0 & $\begin{array}{l}\text { Wind sheltering coefficient, } \\
\text { dimensionless }\end{array}$ \\
DYNSHD & 1.0 & 0.6 & 1.0 & $\begin{array}{l}\text { Allows all incoming solar to reach } \\
\text { the water surface } \\
\text { TSED }\end{array}$ \\
AZC & W2N & 10.5 & 10.7 & $\begin{array}{l}\text { Sediment temperature, }{ }^{\circ} \mathrm{C} \\
\text { Vertical turbulence closure } \\
\text { algorithm }\end{array}$ \\
FRICC & CHEZY $(70.0)$ & MANN $(0.06)$ & CHEZY $(70.0)$ & $\begin{array}{l}\text { Bottom-friction calculation method } \\
\text { Maximum vertical eddy viscosity, } \\
\mathrm{m}^{2} / \mathrm{s}\end{array}$ \\
AZMAX & 0.005 & 1.0 & 0.1 & $\begin{array}{l}\text { Light extinction coefficient for } \\
\text { water, } \mathrm{m}^{-1}\end{array}$ \\
\hline
\end{tabular}

The simulated temperature time series from the calibrated model compare well with the measured time series data at USGS station 14148000 for each calendar year (fig. 11). However, the model underpredicted slightly at some high temperatures and overpredicted at some low temperatures. The seasonal variations from the model during June-July 2002 and October 2011 were slightly cooler than the measured temperatures. Conversely, measured temperatures during the winter of 2008 and the summer of 2011 were slightly cooler than model predictions.

An error analysis was conducted to determine the acceptability of model results. The goodness-of-fit statistics included the mean error (ME), the mean absolute error (MAE), and the root mean square error (RMSE). The results from each of these analyses are shown in table 6 . Overall, the results from the MFWR model temperature calibration matched the measured data well, with the ME between -0.49 and $0.40^{\circ} \mathrm{C}$, the MAE within $0.75^{\circ} \mathrm{C}$, and the RMSE within $1.0^{\circ} \mathrm{C}$. Negative $\mathrm{ME}$ values indicate that the model results were slightly cooler than the measured data. Although no definitive guide exists for evaluating these goodness-of-fit statistics, previous modeling work in many systems has indicated that a well-calibrated W2 temperature model should produce MAE values of less than $1.0^{\circ} \mathrm{C}$ (Rounds, 2010; Sullivan and others, 2011); these model results are consistent with that level of performance.

For 2011, two models were compared with different upstream streamflow and temperature boundary conditions - one that used HCL model output and another that used measured data from USGS station 14145500. Results from both of these 2011 MFWR models were nearly identical (fig. 11, table 6).

A partial accounting for the error between the model and measurement could be attributed to the measurement location. USGS temperature cross sections taken at station 14148000 show a significant amount of cross-sectional variation (as much as $0.6^{\circ} \mathrm{C}$ ), especially in summer. However, the temperature probe is located near the left bank, whereas most of the temperature variation occurs on the right bank, which has slower, shallower water and, therefore, more solar heating throughout a summer day. 


\section{LOP-DEX Model Development-Calibration}

Lookout Point Dam has five radial tainter spillway gates, four ROs, and three power outlets, while Dexter Dam has seven radial tainter spillway gates, one power outlet, and no ROs (U.S. Army Corps of Engineers, 2009) (fig. 7). Centerline elevations for all outflow structures were re-ordered in descending order (to follow rules for blending between outlets in CE-QUAL-
W2, v. 3.7) and reset to the actual elevations in the updated LOP-DEX combined model (U.S. Army Corps of Engineers, 2009; Kathryn Tackley, U.S. Army Corps of Engineers, oral commun., 2012) (table 8). A RO structure was added to the LOP model at centerline of $222.9 \mathrm{~m}$ $(731.3 \mathrm{ft})$ with a line width of 4.0. Top and bottom model outlet structure layers (CE-QUALW2 parameters STR TOP and STR BOT) were adjusted during the temperature calibration.

Table 8. Differences between outlet structure characteristics in original and updated Lookout Point-Dexter Lakes models, Oregon.

[Abbreviations: DEX, Dexter Lake; LOP, Lookout Point Lake; m, meter; n/a, not applicable; Power, power penstock outlet; RO, regulating outlet; STR, structure]

\begin{tabular}{|c|c|c|c|c|c|c|}
\hline \multirow[b]{2}{*}{ Parameter } & \multicolumn{2}{|c|}{ West Consultants model } & \multicolumn{3}{|c|}{ USGS model } & \multirow[b]{2}{*}{ Description } \\
\hline & STR 1 (Power) & $\begin{array}{c}\text { STR 2 } \\
\text { (Spillway) }\end{array}$ & $\begin{array}{c}\text { STR 1 } \\
\text { (Spillway) }\end{array}$ & STR 2 (Power) & STR 3 (RO) & \\
\hline STR TOP (LOP) & 2 & 2 & 2 & 2 & 2 & $\begin{array}{l}\text { Structure top selective } \\
\text { withdrawal limit }\end{array}$ \\
\hline STR BOT (LOP) & 68 & 68 & 49 & 73 & 73 & $\begin{array}{l}\text { Structure bottom selective } \\
\text { withdrawal limit }\end{array}$ \\
\hline \multirow{2}{*}{ STR SINK } & LOP: POINT & LOP: LINE & LOP: LINE & LOP: LINE & LOP: LINE & \multirow{2}{*}{$\begin{array}{l}\text { Sink type used in the } \\
\text { selective withdrawal } \\
\text { algorithm }\end{array}$} \\
\hline & DEX: POINT & DEX: LINE & DEX: LINE & DEX: POINT & DEX: n/a & \\
\hline \multirow{2}{*}{ STR ELEV } & LOP: 237.7 & LOP: 270.5 & LOP: 270.5 & LOP: 240.5 & \multirow{2}{*}{ LOP: 222.9} & \multirow{2}{*}{$\begin{array}{l}\text { Centerline elevation of } \\
\text { structure, } m\end{array}$} \\
\hline & DEX: 197.0 & DEX: 206.2 & DEX: 201.2 & DEX: 196.0 & & \\
\hline \multirow{2}{*}{ STR WIDTH } & LOP: $\mathrm{n} / \mathrm{a}$ & LOP: 75.71 & LOP: 75.71 & LOP: 19.0 & \multirow{2}{*}{ LOP: 4.0} & \multirow{2}{*}{$\begin{array}{l}\text { Width of structure (line } \\
\text { sink), } m\end{array}$} \\
\hline & DEX: n/a & DEX: 109.4 & DEX: 109.4 & DEX: n/a & & \\
\hline
\end{tabular}

\section{Water Balance}

The water balance for Lookout Point Lake was calibrated by comparing measured and modeled water-surface elevations and placing the flow required to close the water budget into a distributed tributary to represent ungaged flows. The resulting comparison between measured and modeled water-surface elevations showed good agreement (fig. 12). For any given time increment, the total amount of flow derived from the distributed tributary inflow can be calculated by dividing the distributed tributary inflow by the total inflow, and the percentage of flow from the distributed tributary varied depending on the calendar year of interest. Median values ranged from 3.9 (2011) to 20.3 percent (2006). Similarly, 90th percentile values ranged from 15.3 (2011) to 119.7 percent (during an extreme high-flow event during January 2006). 


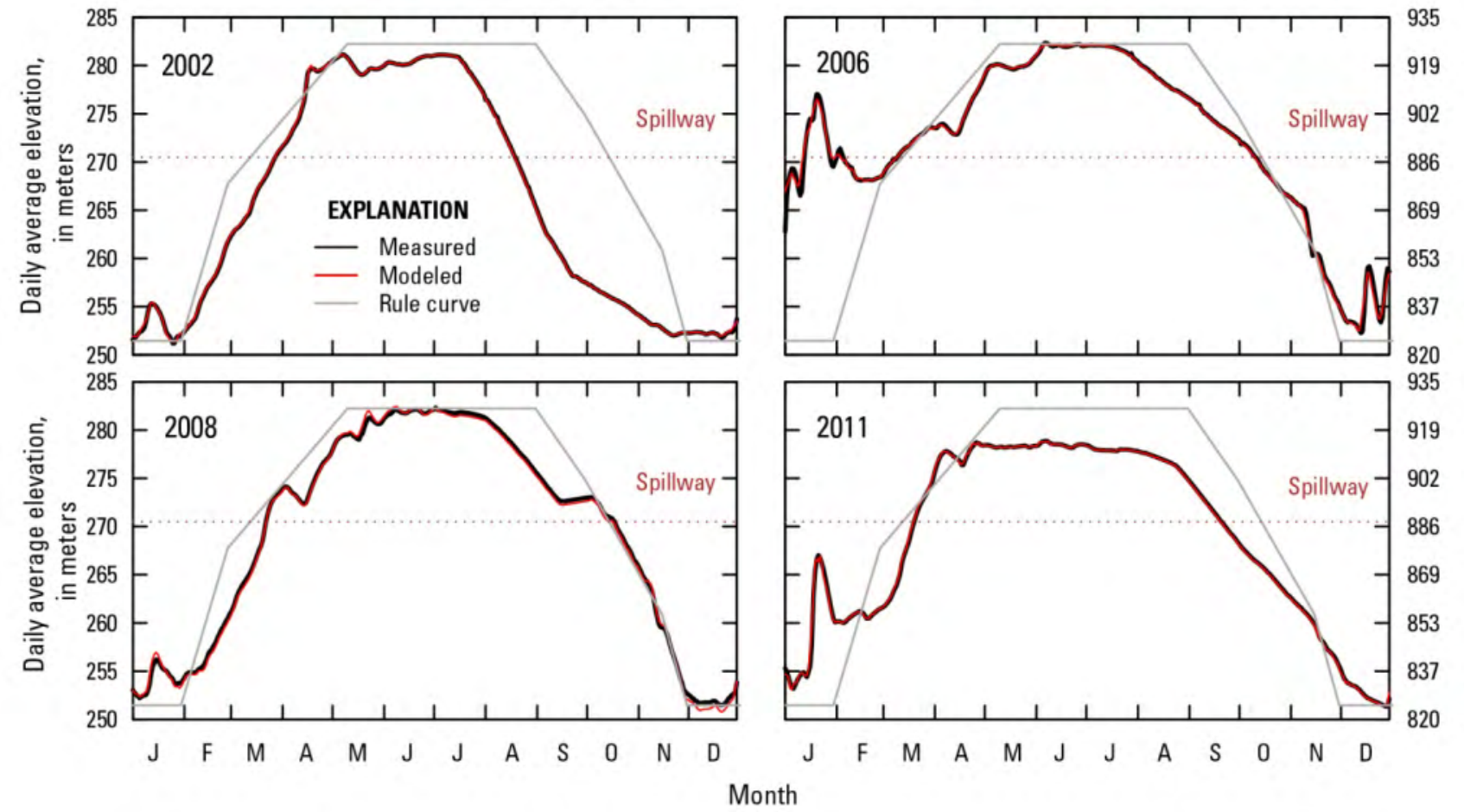

Figure 12. Graphs showing measured and modeled water-surface elevations at Lookout Point Lake, Oregon, 2002, 2006 , 2008, and 2011, along with the target rule curve for the lake.

The water balance for Dexter Lake was more difficult than for Lookout Point Lake (fig. 13). The storage capacity at Dexter Lake $(29,990$ acre-ft) is about 15 times smaller than the storage capacity at Lookout Point Lake (455,800 acre-ft). Therefore, small changes to reservoir inflow resulted in relatively large changes in watersurface elevation. Several algorithms were developed outside of the W2 model to balance inflows with water-surface elevations. Initial attempts were ineffective, as small changes in inflow often resulted in a flooded or completely dry reservoir. Subsequent, iterative attempts provided better results, but required hours or even days of computing time. 


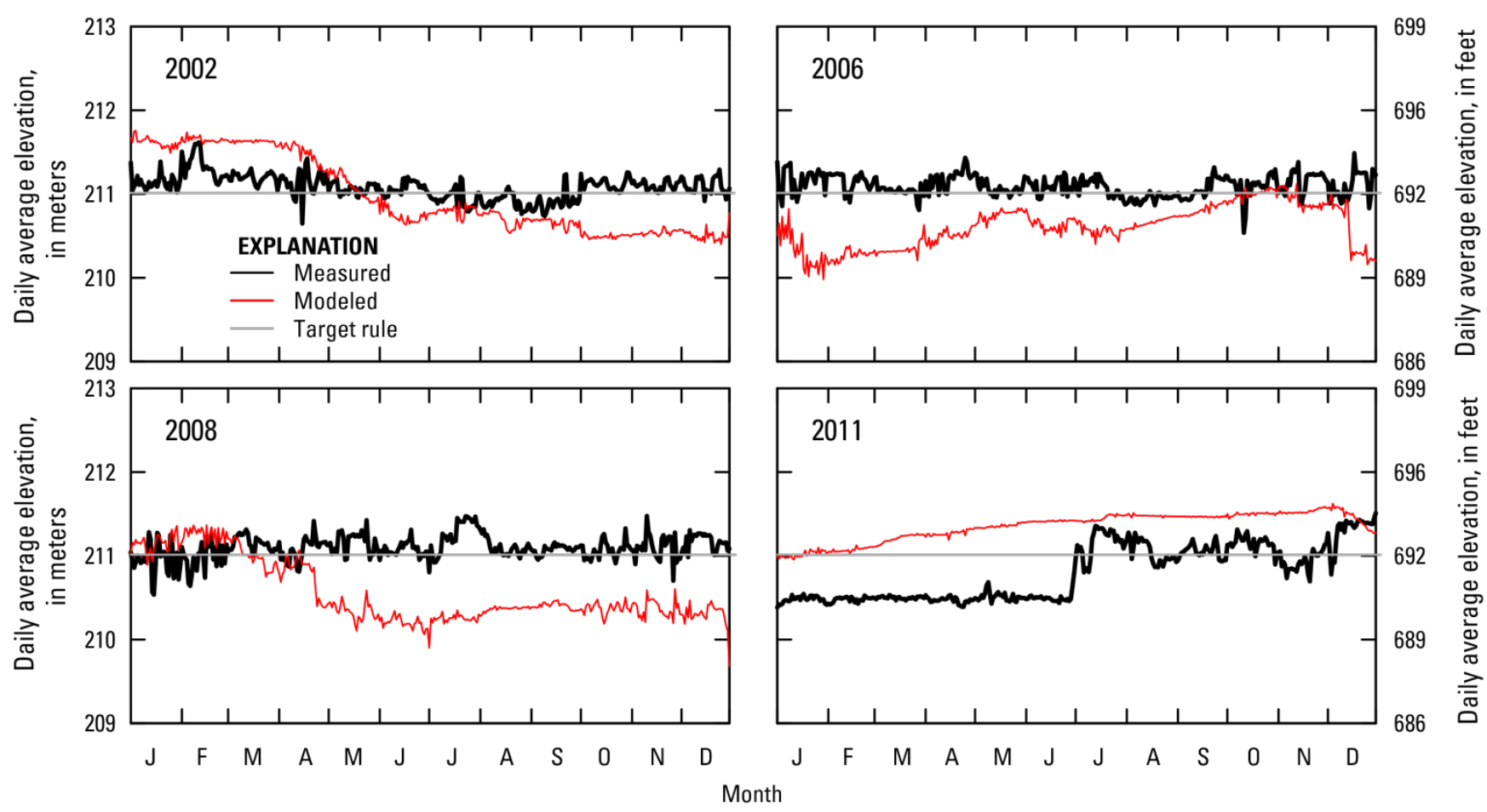

Figure 13. Graphs showing measured and modeled water-surface elevations at Dexter Lake, Oregon, 2002, 2006, 2008 , and 2011, along with the target rule for the lake.

The operating range for the water-surface elevation at Dexter Dam is relatively narrow. During the 4 years used in this study, the lowest reservoir water-surface elevation was $210.27 \mathrm{~m}$ $(689.86 \mathrm{ft})$, and the maximum elevation was $211.78 \mathrm{~m}(694.81 \mathrm{ft})$, allowing for an effective operating range of only $1.51 \mathrm{~m}(4.95 \mathrm{ft})$.

Subsequent analysis showed that attempting to model Dexter Lake at a relatively constant watersurface elevation was much less computationally difficult and time-consuming than attempting to match exact water-surface elevations. A new, iterative algorithm was developed for the Dexter Lake water-balance calculations that attempts to keep water-surface elevations between 210 and $212 \mathrm{~m}$, with a mean elevation of about $211 \mathrm{~m}$.
Model release rates from Lookout Point Dam were from USACE records. Release rates from Dexter Dam were derived by calculating a 3-day moving average of the hourly outflow from Lookout Point Dam. This 3-day averaging window was based on the average residence time calculated by the CE-QUAL-W2 pre-processor for the operating elevation limits at Dexter Lake. Model outflows from Dexter Dam were compared to measured streamflow at USGS station 14150000 (about $2.6 \mathrm{mi}$ downstream of Dexter Dam), and were determined to be satisfactory (fig. 14). 

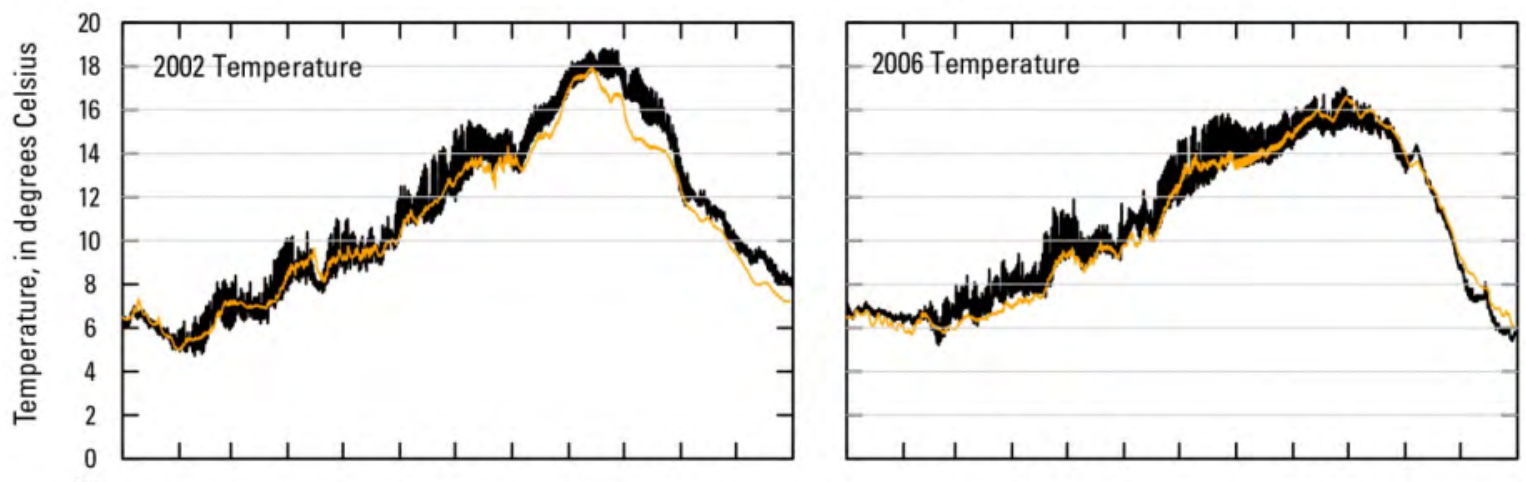

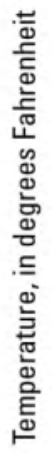
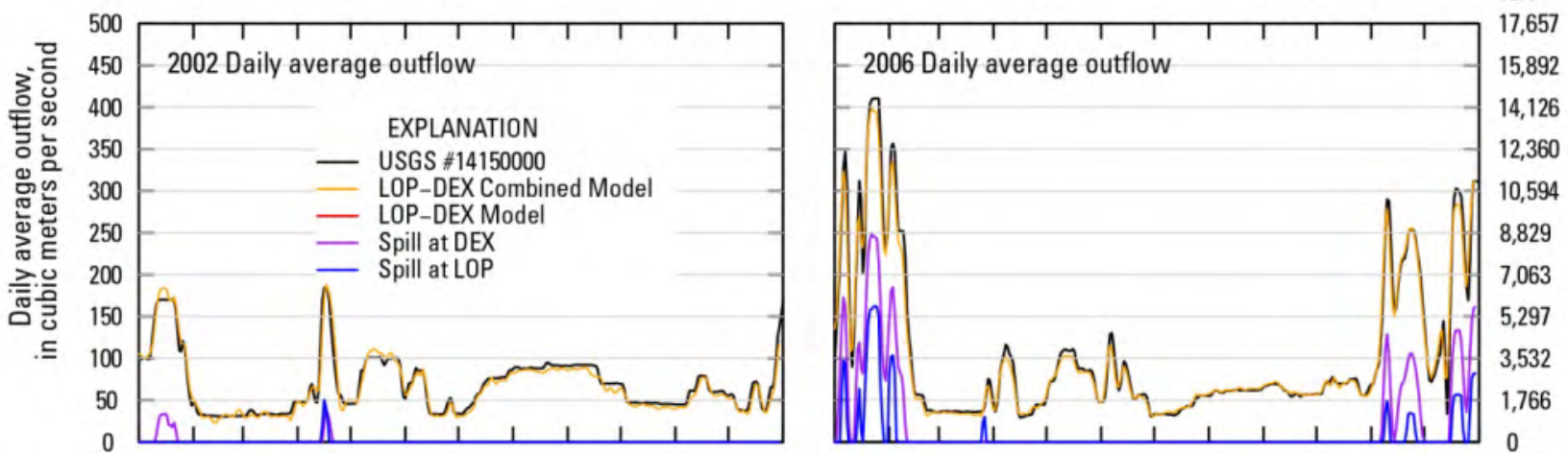

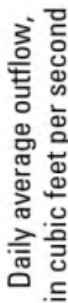
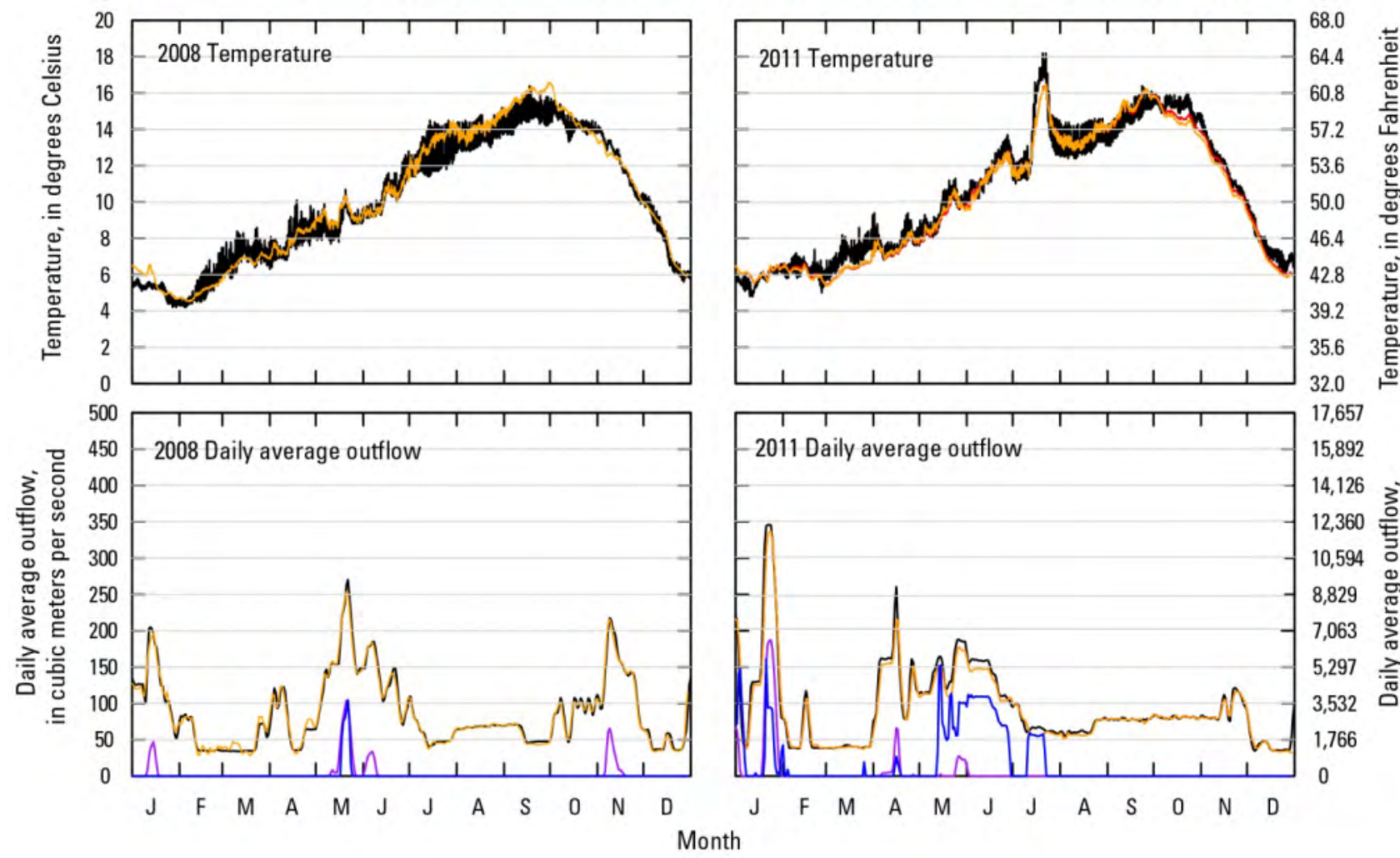

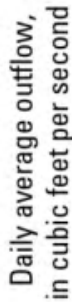

Figure 14. Graphs showing modeled release rates and water temperatures from Dexter Dam and measured streamflow and water temperatures at USGS station 14150000, located 2.6 miles downstream of Dexter Dam, Oregon, 2002, 2006, 2008, and 2011. 


\section{Water Temperature}

After completion of the water balance, initial runs of the CE-QUAL-W2 model for Lookout Point and Dexter Lakes resulted in modeled water temperatures released from Dexter Dam that were cooler than those recorded downstream at USGS station 14150000 . Several changes were made to the original West Consultants model (tables 5 and 8) in an attempt to eliminate these discrepancies. All changes were made based on one or more of the following criteria, in order of importance: (1) Documentation (USACE dam schematics, recorded data, etc.), (2) computed or estimated data (temperature of sediment, etc.), and (3) calibration of the model (light extinction coefficient, etc.). All estimated or calibrated model parameters were evaluated for reasonableness.
The model was initially calibrated to 2011 conditions, which is the most data-rich of the 4 years included in the study and, therefore, providing the greatest amount and highest quality of feedback during the calibration process. Temperature profiles for 2011 at Lookout Point Lake match well with modeled temperatures from the surface to at least $9 \mathrm{~m}$ in depth (fig. 15). From depths of 12-24 m (39-79 ft), the model matches recorded data well for most of the year, but tends to slightly overpredict during the months of warmest water temperatures (August and September). Comparisons of LOP model output with measured temperatures at various depths on eight days in 2002 match well, showing only a small underprediction near the surface (fig. 16). Temperature profiles in Dexter Lake were given less weight during the calibration process. 


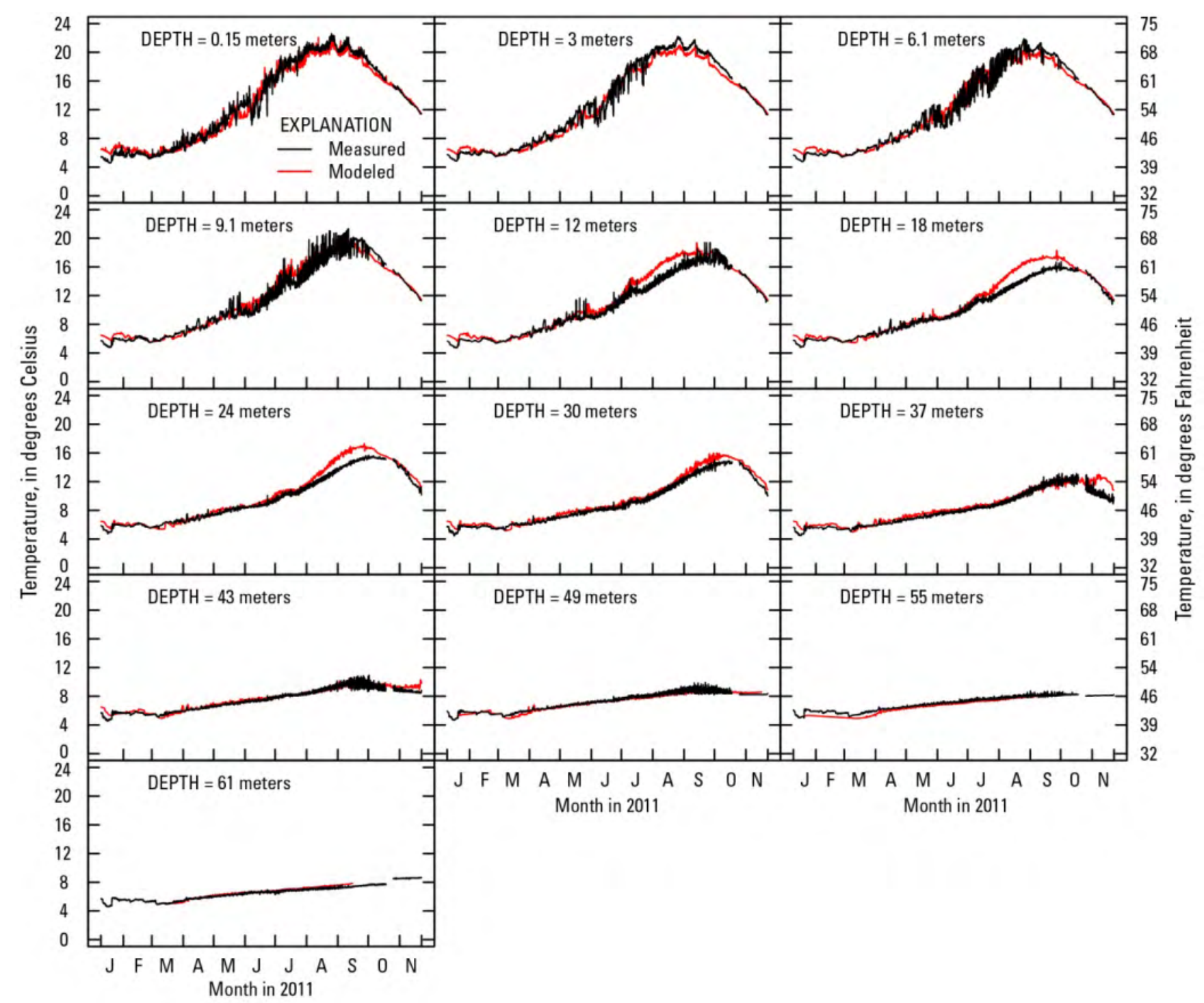

Figure 15. Graphs showing continuous measured and modeled water temperatures at specific depths in Lookout Point Lake near the dam, Oregon, 2011. 
Temperature, in degrees Fahrenheit
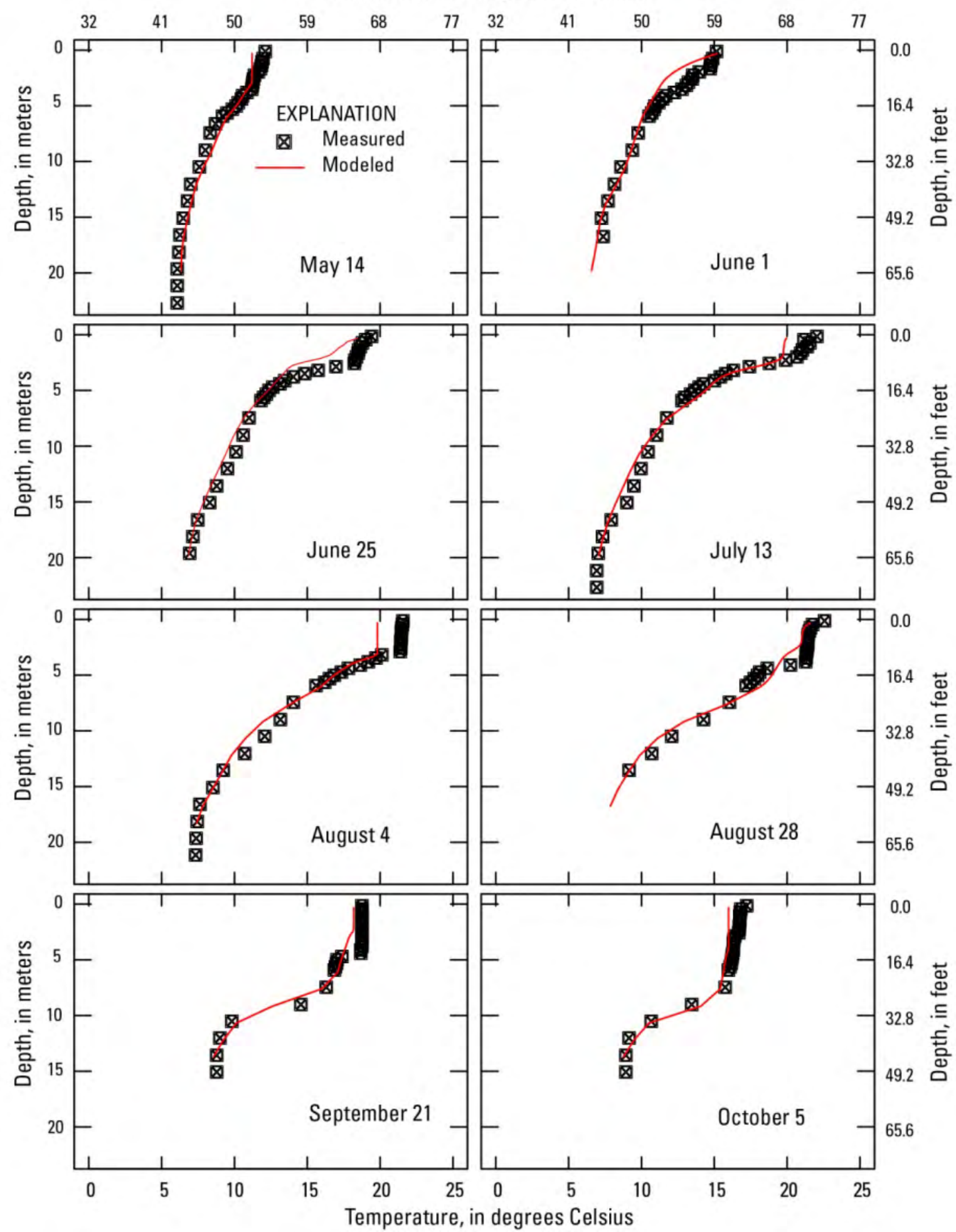

Figure 16. Graphs showing measured and modeled vertical temperature profiles in Lookout Point Lake near the dam, Oregon, 2002. 
As discussed in the section "Water Balance," modeled water-surface elevations in Dexter Lake were held at relatively constant levels compared to measured data for ease of computation. The constant water-surface elevations resulted in a small amount of additional variability to the discrepancy between measured and modeled temperature profiles in Dexter Lake during 2011 (fig. 17). Despite this increase in variability, modeled depth-specific temperatures matched recorded temperatures well, especially near the water surface and near the dam (fig. 18A).

Similar to the LOP temperature profiles, the DEX modeled temperatures were sometimes underpredicted near the surface in the summer months and overpredicted at deeper depths in late summer and autumn of 2011. Similar results were obtained for 2002 conditions at two locations where vertical temperature profiles were measured in Dexter Lake (fig. 18). Near-dam comparisons of modeled temperatures matched well, but "mid-lake" comparisons differed greatly, possibly because of the uncertainty regarding the location of the "mid-lake" measurement in 2002.

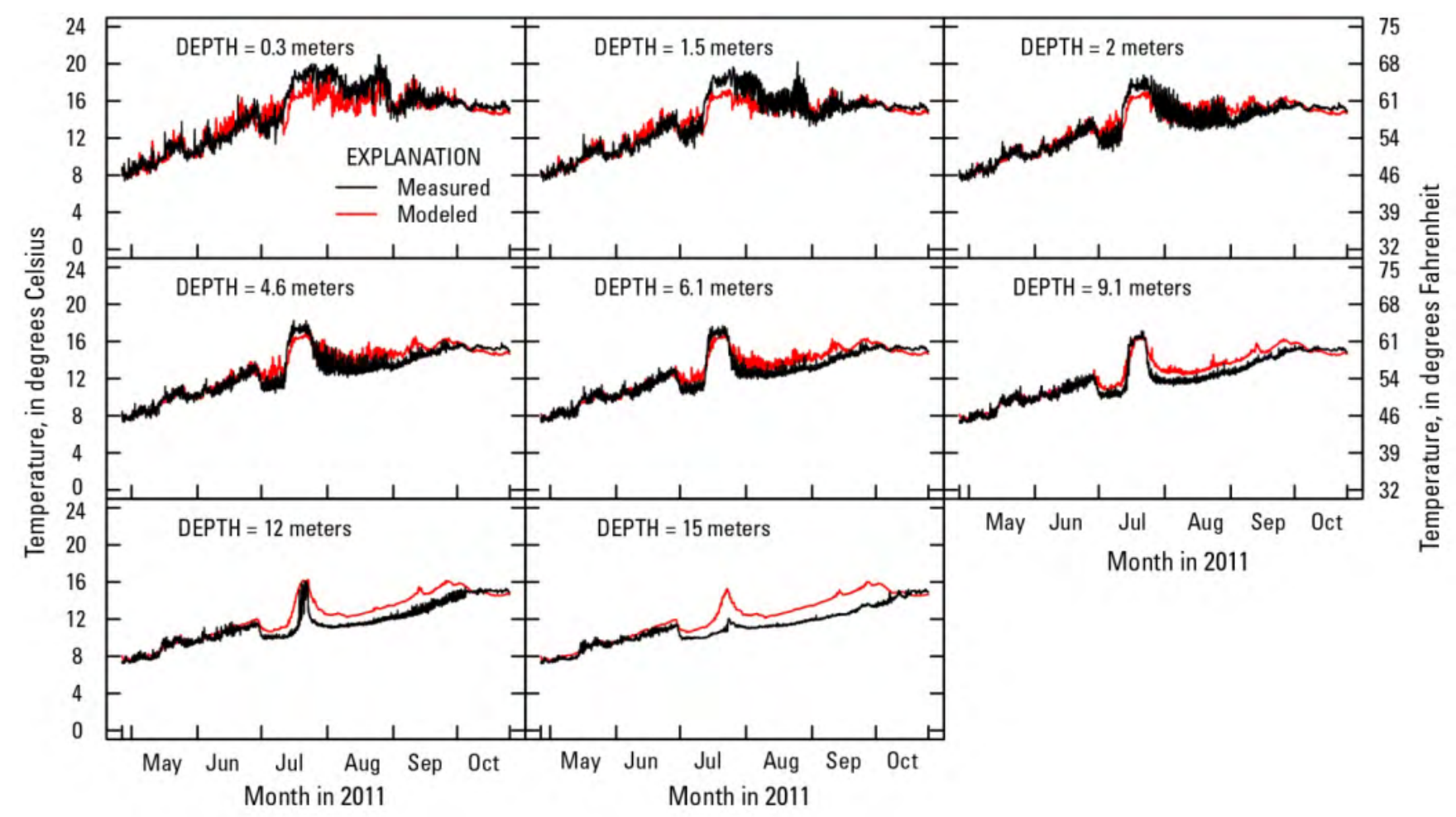

Figure 17. Graphs showing continuous measured and modeled water temperatures in Dexter Lake near the dam, Oregon, 2011. 

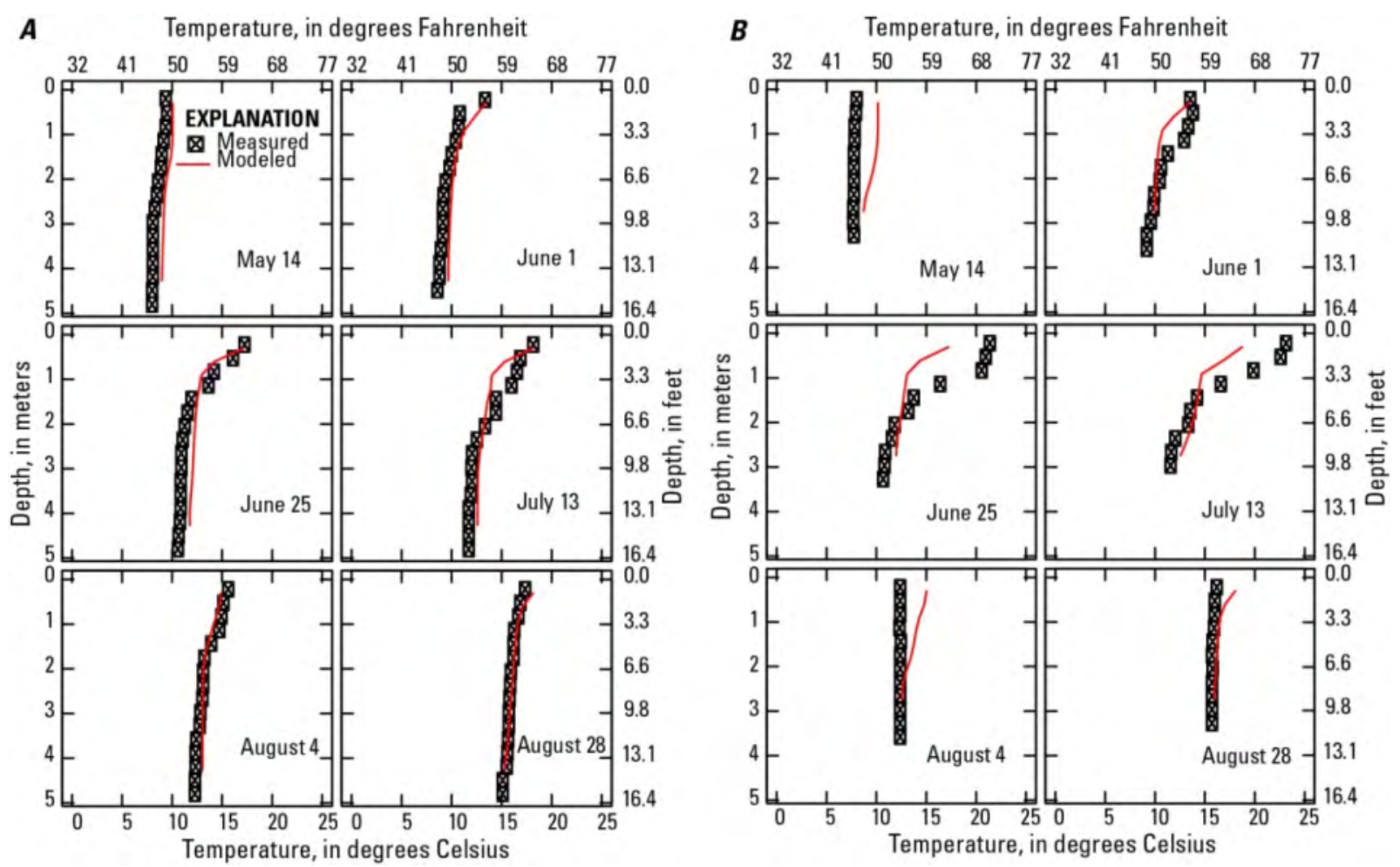

Figure 18. Graphs showing measured and modeled vertical temperature profiles in Dexter Lake, Oregon, 2002, (A) near the dam, and (B) at a mid-lake location.

Modeled temperature outflows for 2011 compared well with data measured at USGS station 14150000 downstream of Dexter Dam (fig. 15). ME and MAE fit statistics for that comparison were well within acceptable limits at -0.15 and $0.44^{\circ} \mathrm{C}$, respectively (table 6). Because USGS station 14150000 is 2.6 mi downstream of Dexter Dam, temperatures may warm during travel between the dam outlets and the gage, especially during the summer months of June, July, and August. Based on Rounds (2010), water temperatures could increase by as much as $0.29^{\circ} \mathrm{C}$ in mid-summer over the course of $2.6 \mathrm{mi}$, explaining some of the slight negative bias in the results.

\section{Combined MFWR Model Development and Calibration}

The HCL, MFWR, and LOP-DEX models were used in series to constitute what is termed the "Combined Model." In the combined model, the streamflow and temperature output from the HCL model was used as input for the MFWR model, and the output of the MFWR model was

used as input for the LOP-DEX model. Results discussed previously were for the individual models run independently with measured upstream inputs.

Boundary conditions between the calibrated and combined models are not geographically identical. The upstream boundary condition used to calibrate the MFWR model is USGS station 14145500 (RM 231.4). Hills Creek Dam is at RM 232.5, which represents the upstream boundary condition for the combined MFWR model. Similarly, the upstream boundary to the LOPDEX model is USGS station 14148000 (RM 220.2), which is about $1.5 \mathrm{mi}$ upstream of the Middle Fork Willamette River model output at segment 85 (RM 218.7). Outflow boundary conditions at LOP and DEX were identical between the combined MFWR model and the independently calibrated LOP-DEX model. These outflows were estimated based on what was necessary to keep the pool elevation constant in Dexter Lake. 
The designated warm and dry year, 2002, was the most difficult to simulate with the combined model, and resulted in the highest RMSE, ME, and MAE of the 4 calendar years evaluated. Outflow temperatures for the combined model were biased $0.43^{\circ} \mathrm{C}$ low in 2002 , with the most pronounced bias occurring in September-December (fig. 14, table 6). Simulated temperatures during the rest of the year matched well with measured temperature data downstream of Dexter Dam, with a mean absolute error of $0.63^{\circ} \mathrm{C}$. The year 2002 also was the year that showed the most spatial variability in temperature cross sections measured at USGS station 14150000 (as high as $0.7^{\circ} \mathrm{C}$ ). Temperature variability was lower in other calendar years, and average cross-sectional temperature variation typically was within $0.3^{\circ} \mathrm{C}$ of the recorded probe values. High variability of temperature cross sections and poorer goodness-of-fit statistics in 2002 could be related. Instream temperature variability typically results in colder water in the middle of the cross section, and warmer water near the banks. As the summer of 2002 was especially warm and dry, the width of the stream could have diminished, resulting in the exposure of the temperature probe to more shallow, slower water than in normal summer conditions. This would produce warmer recorded temperatures than the stream average. This potential discrepancy, combined with the $2.6 \mathrm{mi}$ of exposure to additional solar heating between the dam and the gaging station, could account for some or all of the bias observed in 2002 .

Annual bias of the combined model was small for 2006, 2008, and 2011 (within $0.26^{\circ} \mathrm{C}$; table 6). In 2002, a negative bias was most pronounced in the spring, and a positive bias extended through much of the autumn and early winter. The most pronounced bias in 2008 occurred in January and September, with the rest of the year matching well with the measured data. The overall accuracy of the combined model was good, with MAE values of $0.63^{\circ} \mathrm{C}$ or less for the most downstream temperature comparison for each of the 4 years simulated.

For 2011, the temperature releases from Dexter Dam from the combined model and the calibrated model were nearly identical, resulting in RMSE, ME, and MAE fit statistics that were within $0.05^{\circ} \mathrm{C}$ of each other (table 6). In the combined model, some perceptible negative bias was present in March and October-December, and some perceptible positive bias may be evident in September (fig. 14), but the overall match to the measured data was excellent. Both the independently calibrated and combined models capture the use of the spillway in July 2011 (see the anomalous increase in release temperature in fig. 14) with only a minor underprediction.

\section{Green Peter and Foster Lake Models}

\section{Study Area}

The South Santiam River is part of the larger Santiam River Basin (fig. 19), which is located north of the Middle Fork Willamette River Basin (fig. 1). The entire watershed lies in the Western Cascades High Montane ecoregion, with climate characterized by warm, dry summers and cool, wet winters (E\&S Environmental Chemistry, Inc., and South Santiam Watershed Council, 2000). The South and Middle Santiam Rivers are impounded by two USACE dams that form Foster and Green Peter Lakes, respectively. The reservoirs are used for flood-damage protection, power generation, irrigation, recreation, and improvement of downstream navigation. 


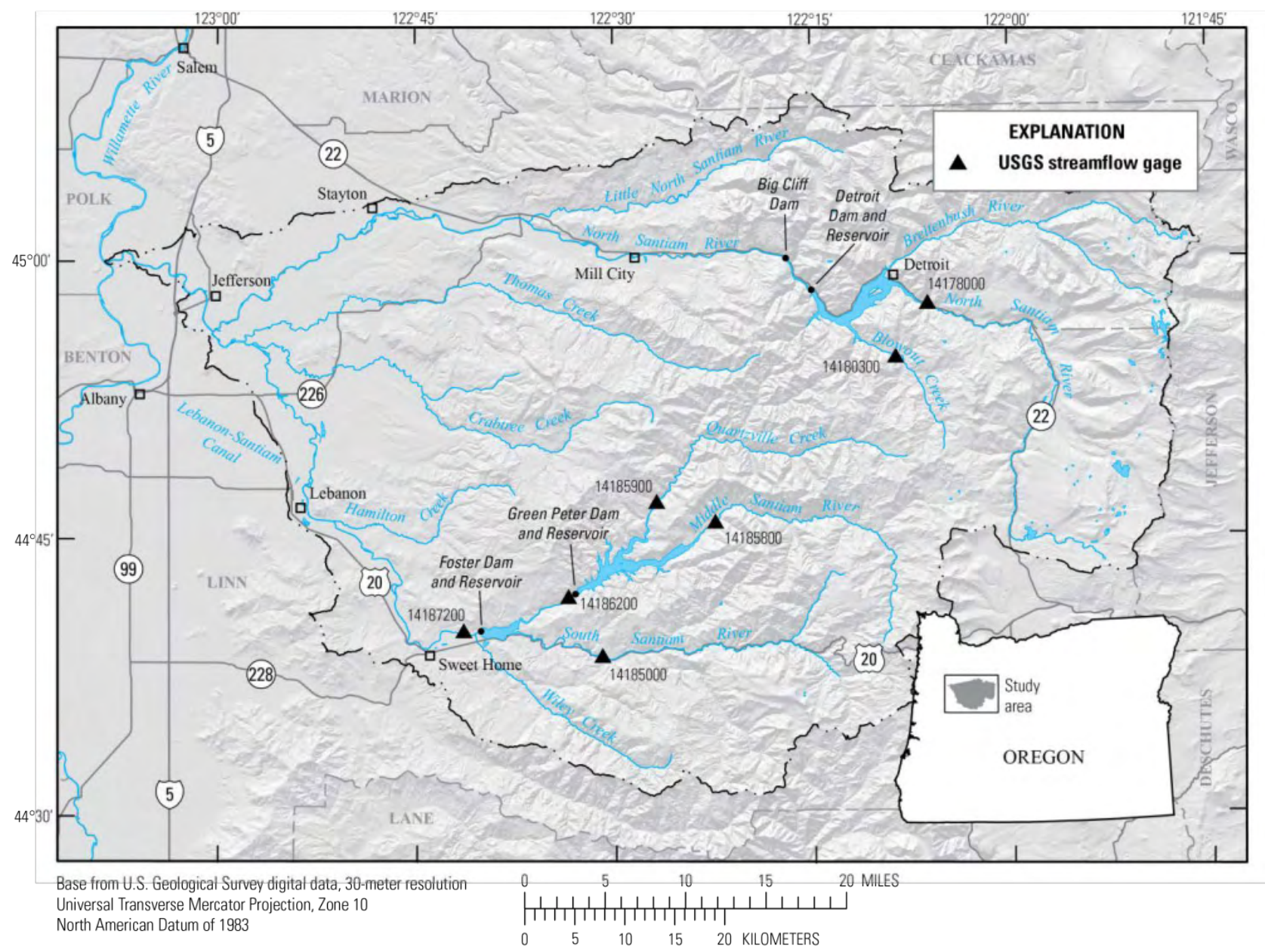

Figure 19. Map showing the Santiam River Basin, Oregon, including the South Santiam River Basin study area and key streamflow-gaging sites.

Green Peter Dam is a 327-ft-high (100-mhigh) concrete dam completed in 1968. The watershed upstream of Green Peter Dam includes $275.3 \mathrm{mi}^{2}$ of mostly evergreen forest and scrubshrub that is managed primarily by the U.S. Forest Service, Bureau of Land Management, and private interests (Johnson and others, 1985). The reservoir formed by Green Peter Dam is about 11 $\mathrm{mi}$ long and stores 428,100 acre- $\mathrm{ft}\left(5.28 \times 10^{8} \mathrm{~m}^{3}\right)$ of water at a full pool elevation of $1,015 \mathrm{ft}(309$ $\mathrm{m})$. The two largest inflows to Green Peter Lake are the Middle Santiam River and Quartzville Creek. Power generation at Green Peter Dam during peak use hours can lead to large fluctuations in release flows to the Middle Santiam River downstream of the dam.
Foster Dam is about $8 \mathrm{mi}$ downstream of Green Peter Dam. Foster Dam is a re-regulating dam that is operated to smooth the irregular flows released from Green Peter Dam. Construction of this rock-fill dam was completed in 1968. The Foster Lake drainage basin includes $216.3 \mathrm{mi}^{2}$ of evergreen forest and scrub-shrub that is managed largely by the U.S. Forest Service and private entities (Johnson and others, 1985). Foster Lake stores 60,700 acre- $\mathrm{ft}\left(7.49 \times 10^{7} \mathrm{~m}^{3}\right)$ of water at a full pool elevation of $641 \mathrm{ft}$. Major inflows to Foster Lake include the Middle and South Santiam Rivers.

Winter Steelhead and spring Chinook Salmon are anadromous fish native to the South Santiam River Basin, and both are listed as threatened under the Endangered Species Act 
(E\&S Environmental Chemistry, Inc., and South Santiam Watershed Council, 2000). Upper Willamette River Chinook Salmon in the South Santiam River are considered to be at high risk of extinction (McElhany and others, 2007), and water temperature affected by dam operations is thought to be a limiting factor (National Marine Fisheries Service, 2008). Alteration of water temperatures downstream of high-head dams can affect fish factors such as cues for migration and spawning, the emergence timing of juvenile fish, and egg mortality (U.S. Army Corps of Engineers, 2012b). South Santiam River temperature effects on aquatic life vary from year to year. For example, although autumn water temperatures downstream of Foster Dam were warmer than ideal for spring Chinook spawning in 2010, conditions in 2011 were close to ideal, despite no active temperature management (U.S. Army Corps of Engineers, 2012b).

\section{Methods and Data}

The USGS Green Peter Lake (GPR) and Foster Lake (FOS) models for 2002, 2006, 2008, and 2011 developed in this study were based on CE-QUAL-W2 models of the reservoirs developed by West Consultants, Inc. (2005) for 1970-2002. For the current study, the model grid and some model parameters were the same as those used in the West Consultants model. However, different input datasets were developed for the years modeled in this study, and some model parameters were changed during the process of calibration (table A3). The USGS GPR and FOS CE-QUAL-W2 models were developed to simulate water-surface elevations, flow, velocities, and water temperatures.

\section{Green Peter and Foster Lake Model Grids}

The model grid developed by West Consultants, Inc. (2005) was used in this study. They developed the grid using digitized maps of the study area before the reservoirs were filled. The resulting grid was found to agree within 5 percent of the USACE volume-elevation curves (West Consultants, Inc., 2005). The part of the model grid representing Green Peter Lake was composed of six branches representing the main channel of the Middle Santiam River, Quartzville Creek, and four minor tributaries to the reservoir. Segment lengths ranged from 377.2 to $2,921.1 \mathrm{~m}$, with 0.50 -m-high vertical layers. The part of the model grid representing Foster Lake included the riverine reach immediately downstream of Green Peter Lake as well as Foster Lake. One branch represented the Foster Lake main channel and a second branch represented the South Santiam reach of Foster Lake reservoir. Segment lengths ranged from 505.8 to $510.4 \mathrm{~m}$, with vertical layers $1 \mathrm{~m}$ high. The GPR and FOS model grids are set up as two "waterbodies" within one CEQUAL-W2 model.

\section{Boundary Conditions}

\section{Meteorological Data}

CE-QUAL-W2 requires air temperature, dew-point temperature, cloud cover, solar radiation, wind speed, and wind direction as meteorological inputs; the same meteorological inputs were used for the Green Peter Lake and Foster Lake waterbodies in the model. Air temperature from Foster Dam weather stations (FWSO) was available and used for all 4 years. Measured air temperature and relative humidity at FWSO in 2006, 2008, and 2011 were used to calculate dew-point temperature (Linsley and others, 1982):

$$
\begin{aligned}
T_{d}=T_{a}-[ & \left(14.55+0.114 T_{a}\right) X \\
& +\left[\left(2.5+0.007 T_{a}\right) X\right]^{3} \\
& \left.+\left(15.9+0.117 T_{a}\right) X^{14}\right](4)
\end{aligned}
$$

where

$T_{d}=$ dew-point temperature, in degrees Celsius; $T_{a}=$ the air temperature, in degrees Celsius; and $X=1.00-\left(\frac{f}{100}\right)$, where $f=$ relative humidity, in percent.

Relative humidity was not measured at Foster Dam in 2002, so air temperature and humidity from the University of Oregon Solar Radiation Monitoring Laboratory (SRML) were 
used to estimate dew-point temperature in that year. Measured air temperature at FWSO was similar to air temperature at SRML that year.

Solar radiation data for the models were obtained from SRML. Some solar data were available at Foster Dam for part of the period modeled. A comparison between the Foster and SRML solar data in 2011 showed similar seasonal and daily patterns of solar radiation at those two locations.

Various sources of wind data were compared for possible use as model input. Wind speeds varied widely between sites. After some initial testing with the models, wind speed and wind direction from the Eugene airport were used for all years, and when necessary the effective wind speed was adjusted with the wind sheltering coefficient during model calibration.

The CE-QUAL-W2 cloud-cover input was derived from Eugene airport observations and converted to CE-QUAL-W2 model units using the same method as discussed for the Middle Fork Willamette River models.

Precipitation data were available from Foster Dam site FWSO for 2006, 2008, and 2011. Precipitation data from the Detroit Dam for 2002 were used as an estimate of precipitation rates in the study area in 2002. Precipitation temperature was estimated as air temperature, with any negative air temperature values set to zero.

\section{Hydrologic Data}

Streamflow was measured at one of the main inflows to Green Peter Lake, Quartzville Creek (USGS station 14185900, fig. 19), in all 4 years modeled. The Middle Santiam River flow into Green Peter Lake was based on Quartzville Creek flows, as estimated from a regression equation documented by West Consultants, Inc. (2005). The flows for Whitcomb, Thistle, Tally, and Rumbaugh Creeks were estimated from Quartzville Creek flows and the ratio of their drainage basin area to the Quartzville Creek drainage basin area.
Releases from Green Peter Dam in the years modeled were withdrawn for power generation from a penstock at elevation $810 \mathrm{ft}(246.9 \mathrm{~m})$ or spilled through a RO with a centerline elevation of $750 \mathrm{ft}(228.6 \mathrm{~m})$. The Green Peter Dam spillway was not used in the 4 years modeled; all "spill" was released through the RO. Hourly release rates for these outlets were obtained from USACE. The model was set up to release flows from these two outlets at their specified elevations and to discharge them into the model segment downstream of Green Peter Dam.

The main inflow into the FOS model was the outflow release from Green Peter Lake. Flow from the other major inflow into Foster Lake, the South Santiam River, was measured at USGS station 14185000 in all years modeled.

Releases from Foster Dam were either discharged from a spillway with a crest elevation of $596.8 \mathrm{ft}(181.9 \mathrm{~m})$ or were withdrawn for power generation through a penstock at an elevation of $583.3 \mathrm{ft}(177.8 \mathrm{~m})$. Hourly release data were obtained from USACE, and the model was set to release those flows at the specified outlet elevations.

Forebay water-surface elevations were measured in both Green Peter Lake and Foster Lake. Measured elevations were compared to modeled elevations during the water-balance calibration.

\section{Inflow Water Temperature}

Measured water temperature data at Quartzville Creek were available from USGS for part of 2008 and all of 2011, and from ODEQ for part of 2002. For periods without measured data, a regression equation (Rounds, 2010) between water temperatures in Quartzville Creek and Blowout Creek (USGS station 14180300) in the North Santiam River Basin, along with Blowout Creek water temperatures, was used to estimate hourly Quartzville Creek water temperatures flowing into Green Peter Lake. Measured water temperatures for the Middle Santiam River were available for 2011 at USGS station 14185800, but 
not for the other years. A comparison of Quartzville Creek and Middle Santiam River water temperatures in 2011 showed similar seasonal and daily water temperature patterns; therefore, Quartzville Creek water temperatures were used to estimate Middle Santiam River water temperatures for the years when measured water temperatures were not available. No water temperature data were available for the smaller tributary inflows to Green Peter Lake, including Whitcomb, Thistle, Tally, and Rumbaugh Creeks, so their water temperatures were estimated as equal to Quartzville Creek water temperatures.

The major Foster Lake inflow was the release from Green Peter Lake, and the temperature of that water was determined within the model. That water entered the Foster Lake part of the grid immediately downstream of Green Peter Dam. The water temperature for the South Santiam River inflow was measured from late October 2008 through all of 2011 at USGS station 14185000. To estimate South Santiam River water temperature for 2002, 2006, and part of 2008, a regression was completed between water temperatures for Blowout Creek in the North Santiam River Basin and for the South Santiam River using October 2008-December 2011 half-hourly data (John Risley, U.S.

Geological Survey, written commun., 2012). The resulting equation took the form:

$T_{S S}=0.973+1.1174 T_{m B C}+\left(T_{B C}-\right.$ $\left.T_{m B C}\right)\left(-0.0258 T_{r B C}^{2}+0.7303 T_{r B C}+\right.$ $0.2096) / T_{r B C}$

where

$T_{S S}=$ the estimated water temperature for the South Santiam River inflow to Foster Lake, in degrees Celsius;

$T_{m B C}=$ the measured daily mean water temperature at the Blowout Creek site, in degrees Celsius;

$T_{B C}=$ the half-hourly temperature from Blowout Creek, in degrees Celsius; and

$T_{r B C}=$ the daily temperature range from the Blowout Creek site, in degrees Celsius.

\section{Lake Profile Data and Outflow Water Temperature}

Measured water temperature profiles, thermistor string data, and water temperatures downstream of the dams were used for comparison to modeled temperatures during model calibration. In 2002, vertical profiles of water temperature in Green Peter Lake were measured at two sites, GPTR1 and GPTR4, on nine dates from April to October. Geographic coordinates were not provided for these sites, so their location in the reservoir was estimated from a map provided by West Consultants, Inc. (2005). Site GPTR1 was in the Green Peter Lake forebay (near the dam) and site GPTR4 was upstream of the Rumbaugh Creek confluence with Green Peter Lake. In 2011, water temperatures were measured hourly from a string of 13 thermistors suspended in the Green Peter forebay at depths of 0.5-200 ft (0.2-61 m). Green Peter Lake modeled release temperatures were compared to measured water temperatures about $330 \mathrm{ft}(100 \mathrm{~m})$ downstream of Green Peter Dam at USGS station 14186200, which has measured water temperatures for part of 2008 and all of 2011.

For Foster Lake, water temperatures were measured hourly near the dam in 2011 from 11 suspended thermistors at depths of $0.5-80 \mathrm{ft}(0.2-$ $24.4 \mathrm{~m}$ ). Foster Dam release temperatures were compared to hourly temperatures measured at USGS station 14187200 on the South Santiam River about $0.6 \mathrm{mi}(1 \mathrm{~km})$ downstream of Foster Dam in all years of the study. Wiley Creek flows into the South Santiam River between Foster Dam and station 14187200, so these temperatures are not expected to match exactly, but mixing calculations for 2011 showed that the effect of Wiley Creek on downstream temperatures was minor.

\section{GPR-FOS Model Development/Calibration}

\section{Water Balance}

Preliminary model runs showed that additional flows were needed to complete the water balance. Distributed tributary flow was 
added to the model to account for flow from ungaged tributaries, overland flow during storms, gage errors, and groundwater interactions. In CEQUAL-W2, a distributed tributary apportions that flow to all segments along a branch. Distributed tributary flow varied through the years, and generally was higher in winter and during storms. Because the distributed tributary was likely mostly representative of surface water, the temperature of the distributed tributary was estimated as a mix of 20 percent groundwater with a temperature of $11.1^{\circ} \mathrm{C}$, and 80 percent surface water, represented by Quartzville Creek water temperature for the GPR distributed tributary, and the South Santiam River water temperature for the FOS distributed tributary.

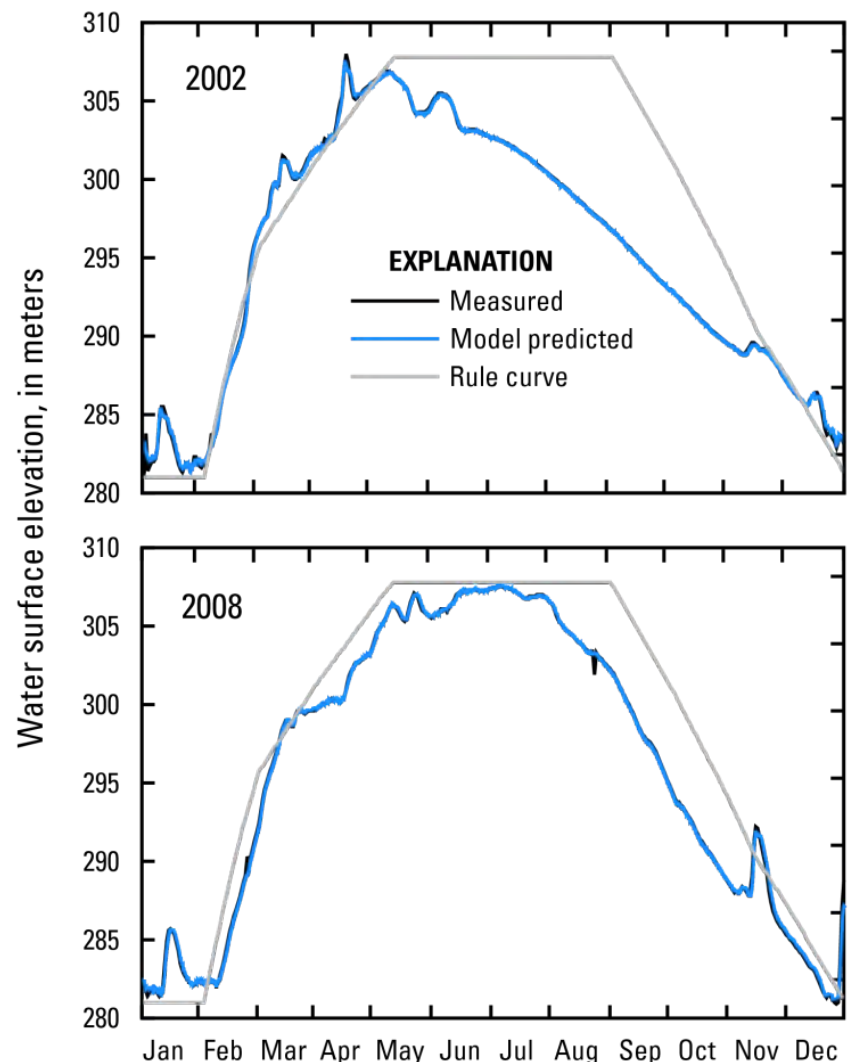

At times, distributed tributary flow was negative, which could indicate seepage loss from the reservoir. On an annual average basis, the GPR distributed tributary was about $9,14,-3$, and 3 percent of total inflows for 2002, 2006, 2008, and 2011, respectively. The FOS distributed tributary was about $2,7,13$, and 16 percent of total inflows for 2002, 2006, 2008, and 2011, respectively. After addition of the distributed tributary, the final modeled forebay water-surface elevations matched the measured water-surface elevations closely for Green Peter Lake and Foster Lake (figs. 20 and 21). The operation of a fish weir in the spillway of Foster Dam from April 15 through May 15 in each year of this study caused lake elevations to be lower than the rule curve at Foster Lake.
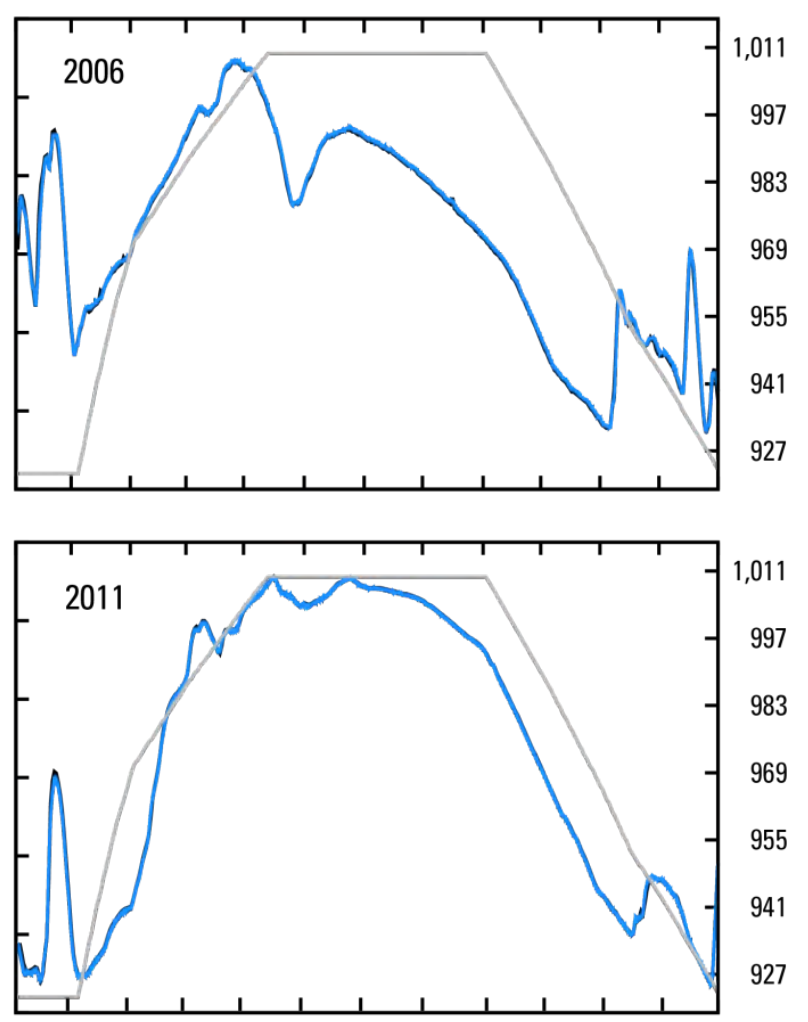

Jan Feb Mar Apr May Jun Jul Aug Sep Oct Nov Dec

Month

Figure 20. Graphs showing measured and modeled forebay water-surface elevations in Green Peter Lake, Oregon, 2002, 2006, 2008, and 2011. 

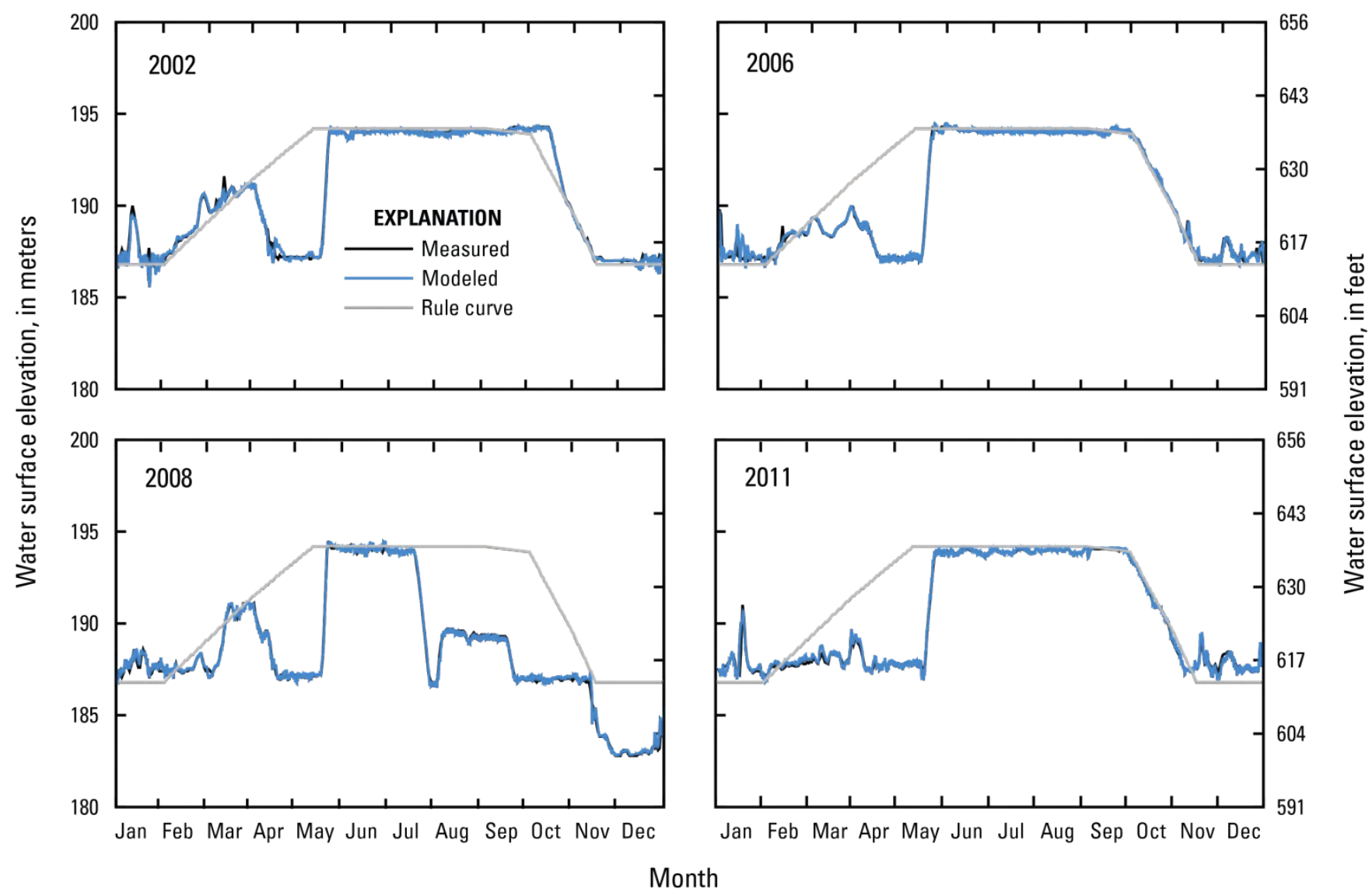

Figure 21. Graphs showing measured and modeled forebay water-surface elevations in Foster Lake, Oregon, 2002, 2006, 2008, and 2011.

\section{Water Temperature}

During model water-temperature calibration, a set of model parameters were adjusted within reasonable bounds to optimize the comparison of measured and modeled water temperatures. Final values for this set of model parameters are shown in table 9. Comparison of modeled water temperatures at specific depths within Green Peter Lake are shown in figures 22 and 23 for comparison to measured temperatures in 2011 and 2002, respectively. Modeled and measured water temperatures just downstream of Green Peter Dam are compared in figure 24 for all 4 years of the study. Depth-specific modeled and measured water temperatures in 2011 within Foster Lake are shown in figure 25. Modeled and measured water temperatures just downstream of Foster Dam for all 4 years are shown in figure 26. Error statistics summarizing this comparison of model output and measured data are shown in table 10. 
Table 9. Selected model parameter values used in the models for Green Peter and Foster Lakes,Oregon. [Abbreviations: ${ }^{\circ} \mathrm{C}$, degrees Celsius; $\mathrm{m}^{2} / \mathrm{s}$, square meters per second]

\begin{tabular}{llll}
\multicolumn{1}{c}{ Parameter } & Green Peter Lake & \multicolumn{1}{c}{ Foster Lake } & \multicolumn{1}{c}{ Description } \\
\hline WSC & 1.0 & 0.5 & Wind sheltering coefficient, dimensionless \\
TSED & 11.1 & 11.1 & Sediment temperature, ${ }^{\circ} \mathrm{C}$ \\
AZC & W2N & W2N & Vertical turbulence closure algorithm \\
AZMAX & 0.001 & 0.001 & Maximum vertical eddy viscosity, $\mathrm{m}^{2} / \mathrm{s}$ \\
EXH2O & 0.45 & 0.60 & Light extinction coefficient for water, $\mathrm{m}^{-1}$ \\
STR SINK & spill: POINT & spill: POINT & $\begin{array}{l}\text { Withdrawal structure type. Withdrawal width (meters) } \\
\text { given for LINE structures. }\end{array}$ \\
& power: POINT & power: LINE (3.8) & Structure Top Selective Withdrawal Limit \\
STR TOP & 2 & 2 & Structure Bottom Selective Withdrawal Limit \\
STR BOTTOM & 185 & 185 &
\end{tabular}

Table 10. Model goodness-of-fit statistics for water temperature for Green Peter and Foster Lakes, Oregon.

\begin{tabular}{lccc}
\hline \multicolumn{1}{c}{$\begin{array}{c}\text { Year and Type of } \\
\text { Measured Data }\end{array}$} & $\begin{array}{c}\text { Mean Error } \\
\text { (ME) }\end{array}$ & $\begin{array}{c}\text { Mean Absolute Error } \\
\text { (MAE) }\end{array}$ & $\begin{array}{c}\text { Root Mean Square Error } \\
\text { (RMSE) }\end{array}$ \\
\hline 2008 Outflow & 0.10 & 0.48 & 0.54 \\
2011 Outflow & -0.28 & 0.45 & 0.58 \\
2002 Depth Profiles & 0.35 & 0.77 & 0.98 \\
2011 Thermistor string & 0.00 & 0.60 & 0.82 \\
\hline & & Foster Lake & \\
\hline 2002 Outflow & -0.12 & 0.43 & 0.55 \\
2006 Outflow & -0.08 & 0.50 & 0.63 \\
2008 Outflow & -0.24 & 0.62 & 0.79 \\
2011 Outflow & -0.19 & 0.65 & 0.79 \\
2011 Thermistor string & -0.01 & 0.72 & 1.06 \\
\hline
\end{tabular}




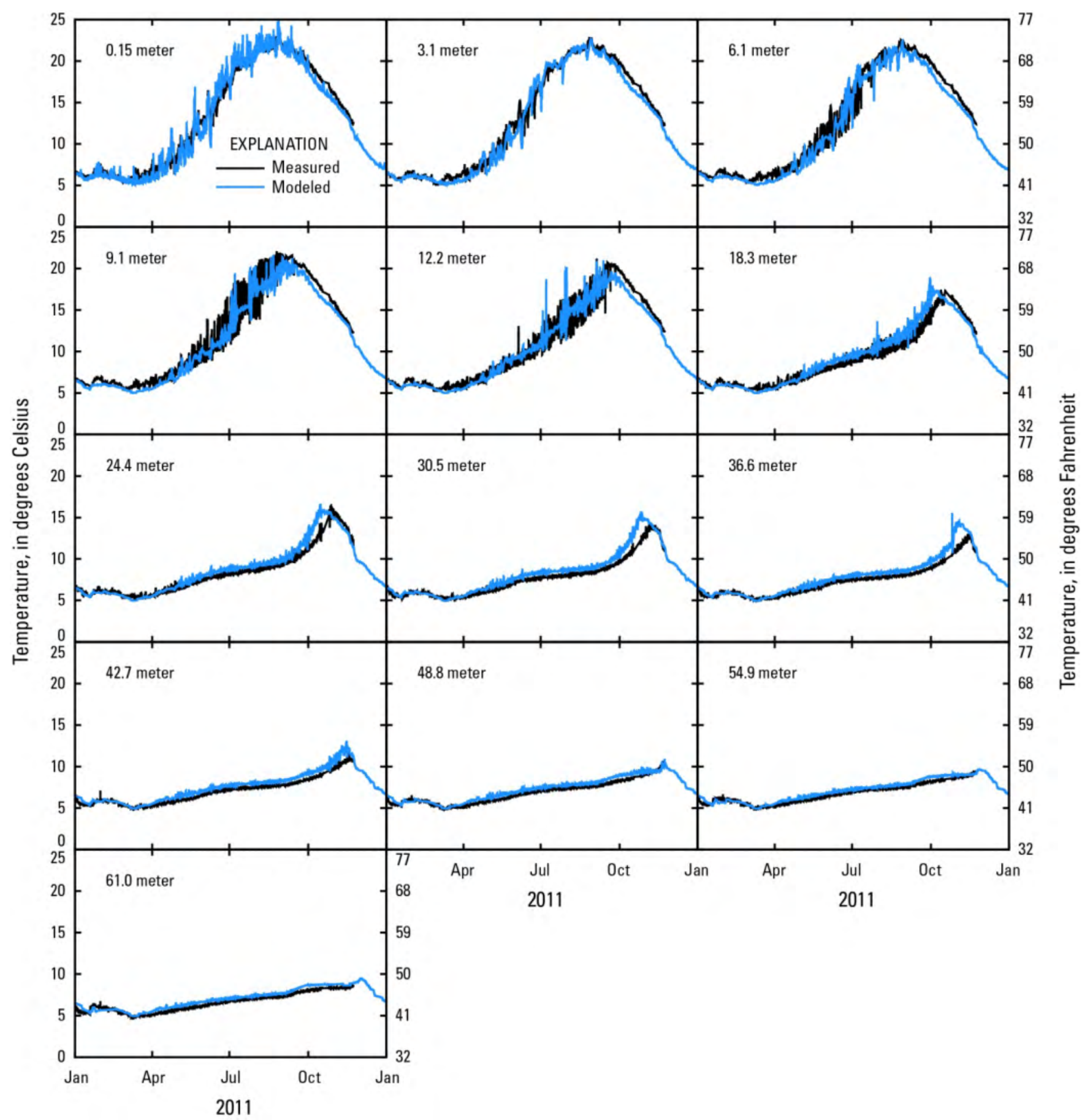

Figure 22. Graphs showing forebay thermistor string data for Green Peter Lake, Oregon, 2011, and model output at the same depths and times. 
Site GPTR1 Temperature, in degrees Fahrenheit

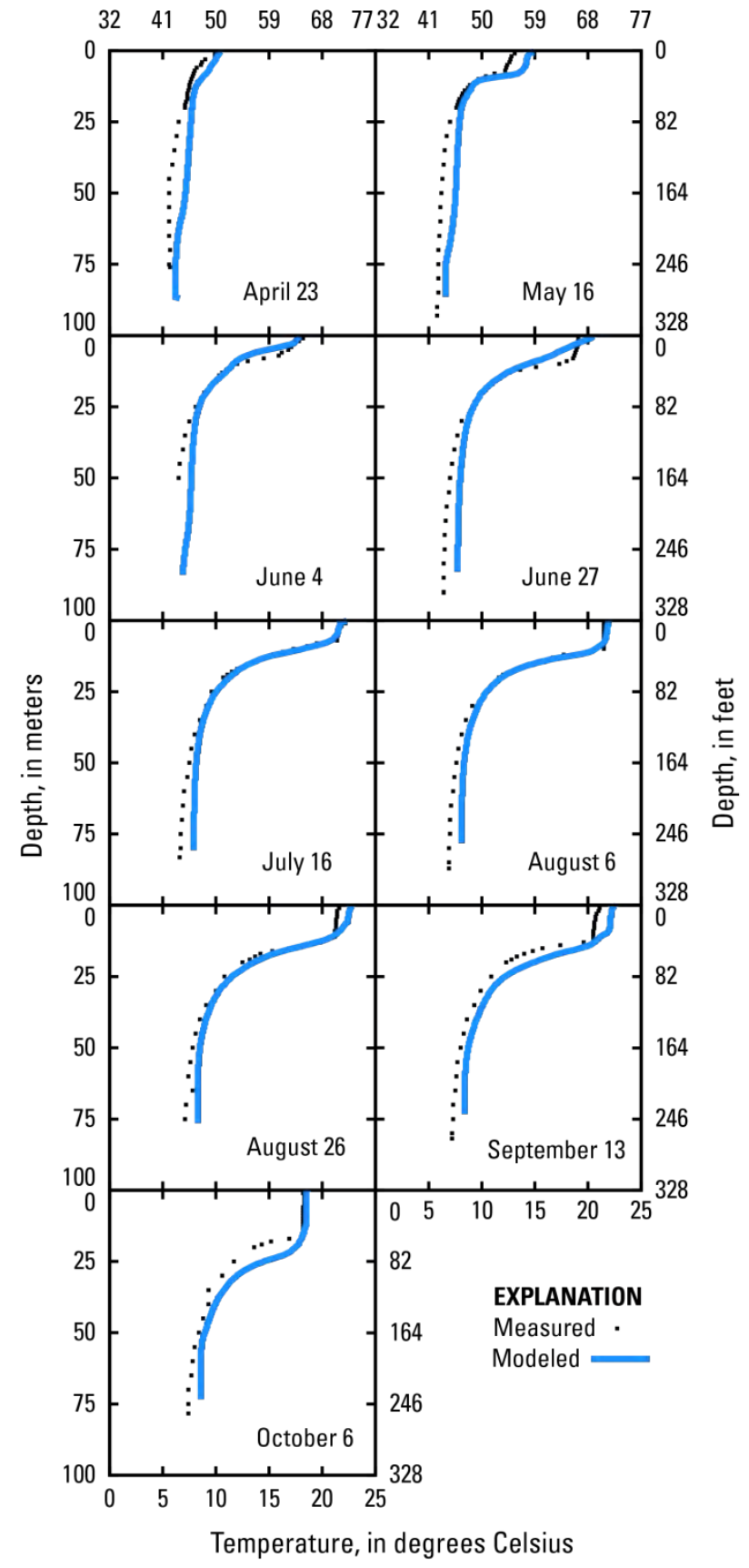

Site GPTR4 Temperature, in degrees Fahrenheit

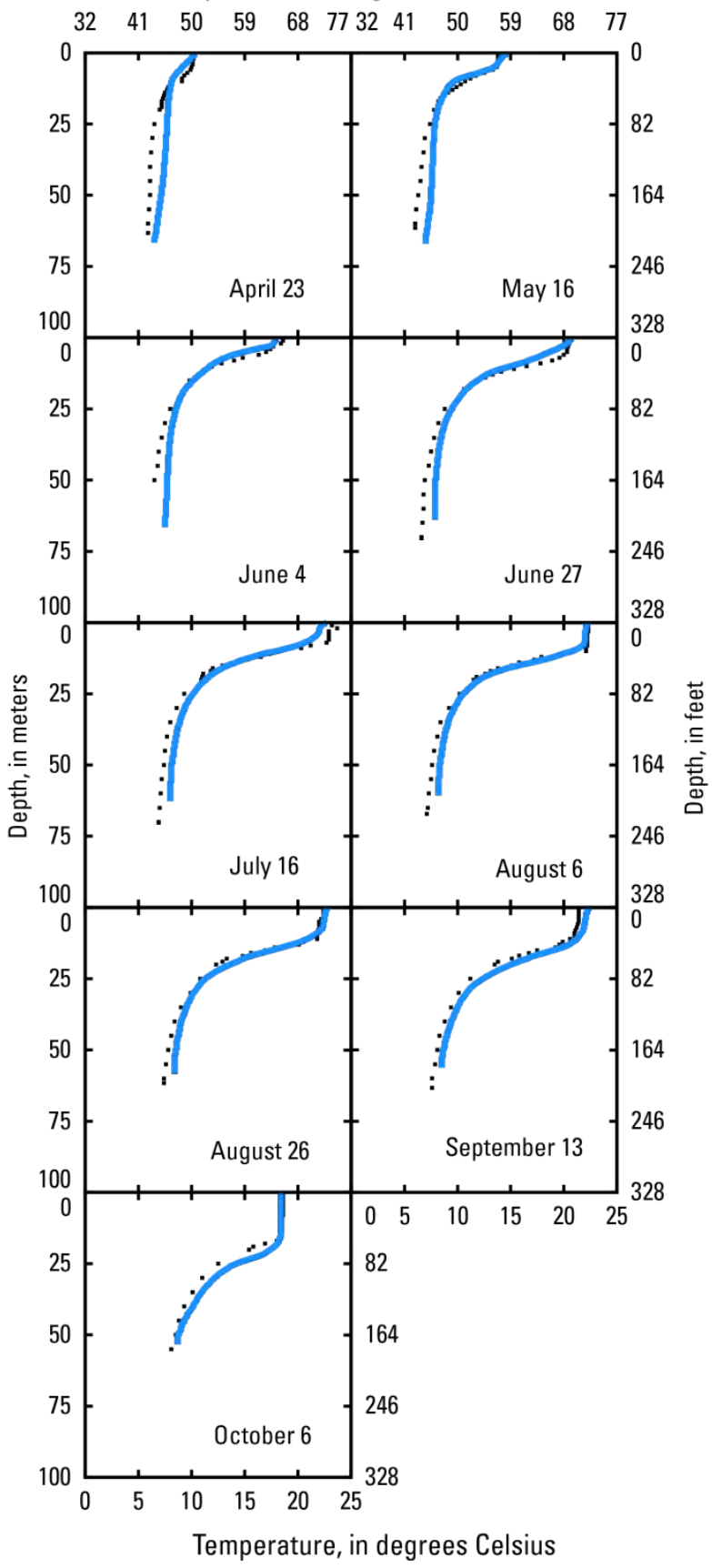

Figure 23. Graphs showing vertical profile temperature data for Green Peter Lake, Oregon, 2002, and model output at the same location and dates. 

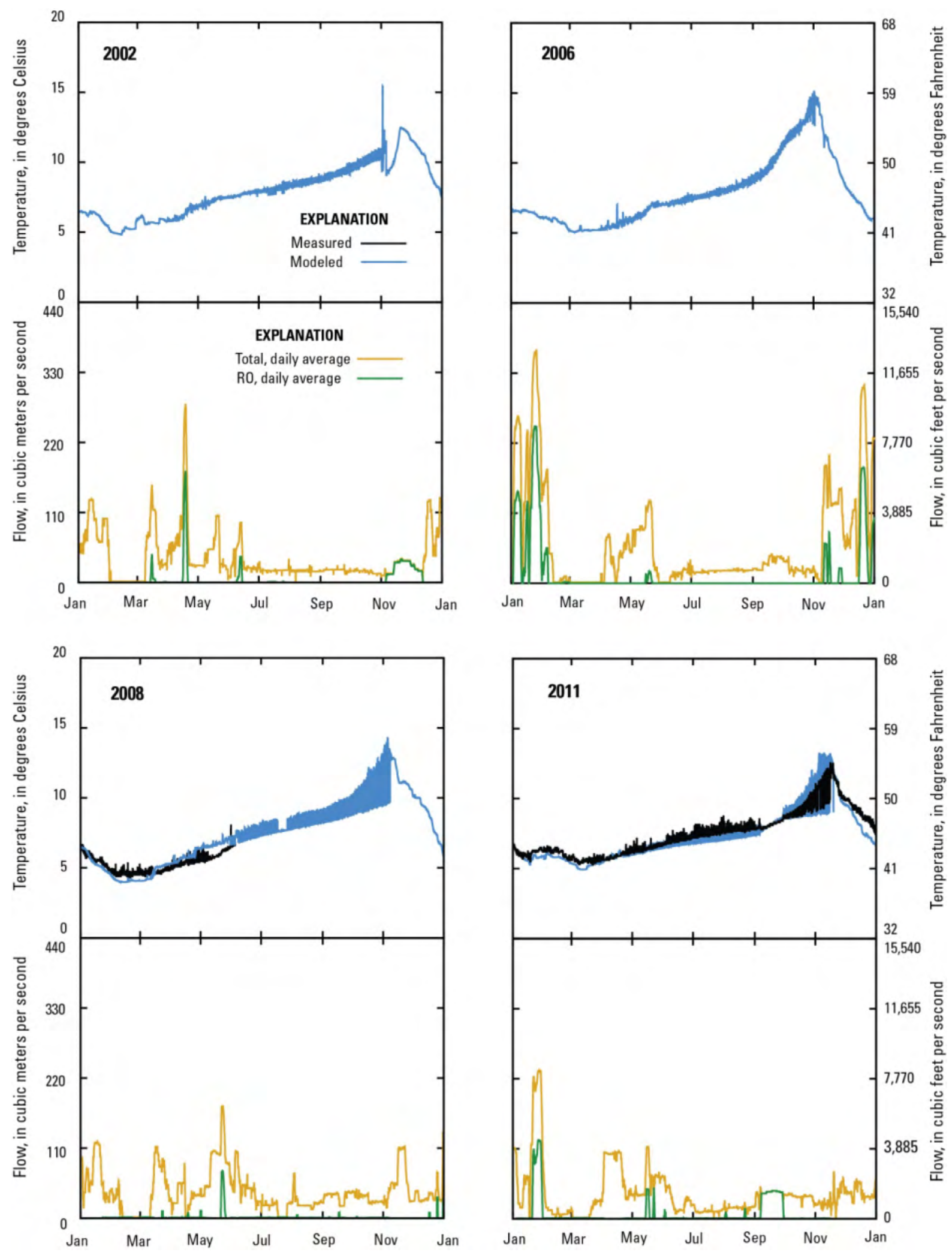

Figure 24. Graphs showing modeled outflow temperatures and measured water temperatures for Green Peter Lake, Oregon, just downstream of Green Peter Dam, and daily average total and regulating outlet (RO) release rates, 2002, 2006, 2008, and 2011. 


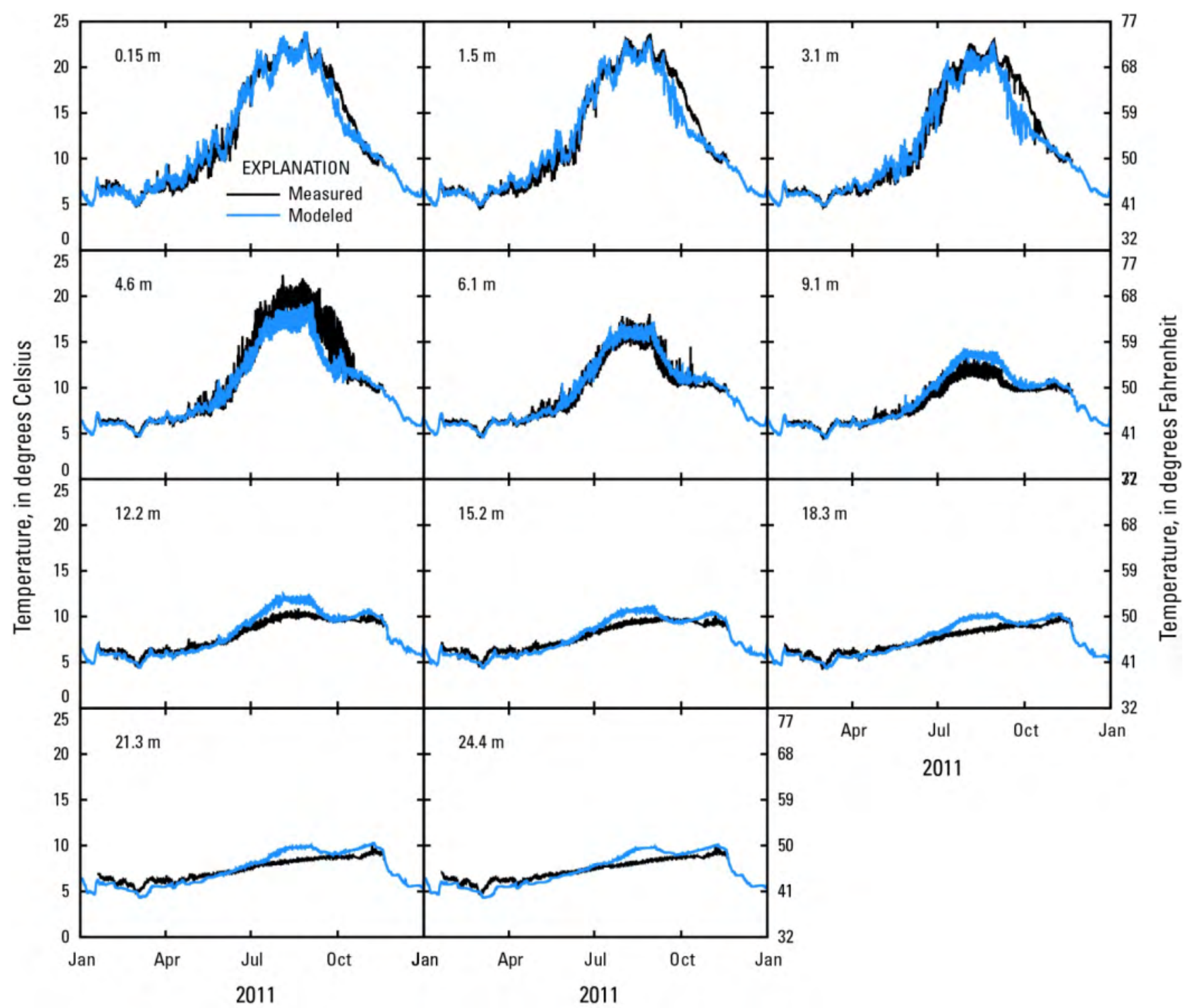

Figure 25. Graphs showing forebay thermistor string data for Foster Lake, Oregon, 2011, and model output at the same depths and times. 

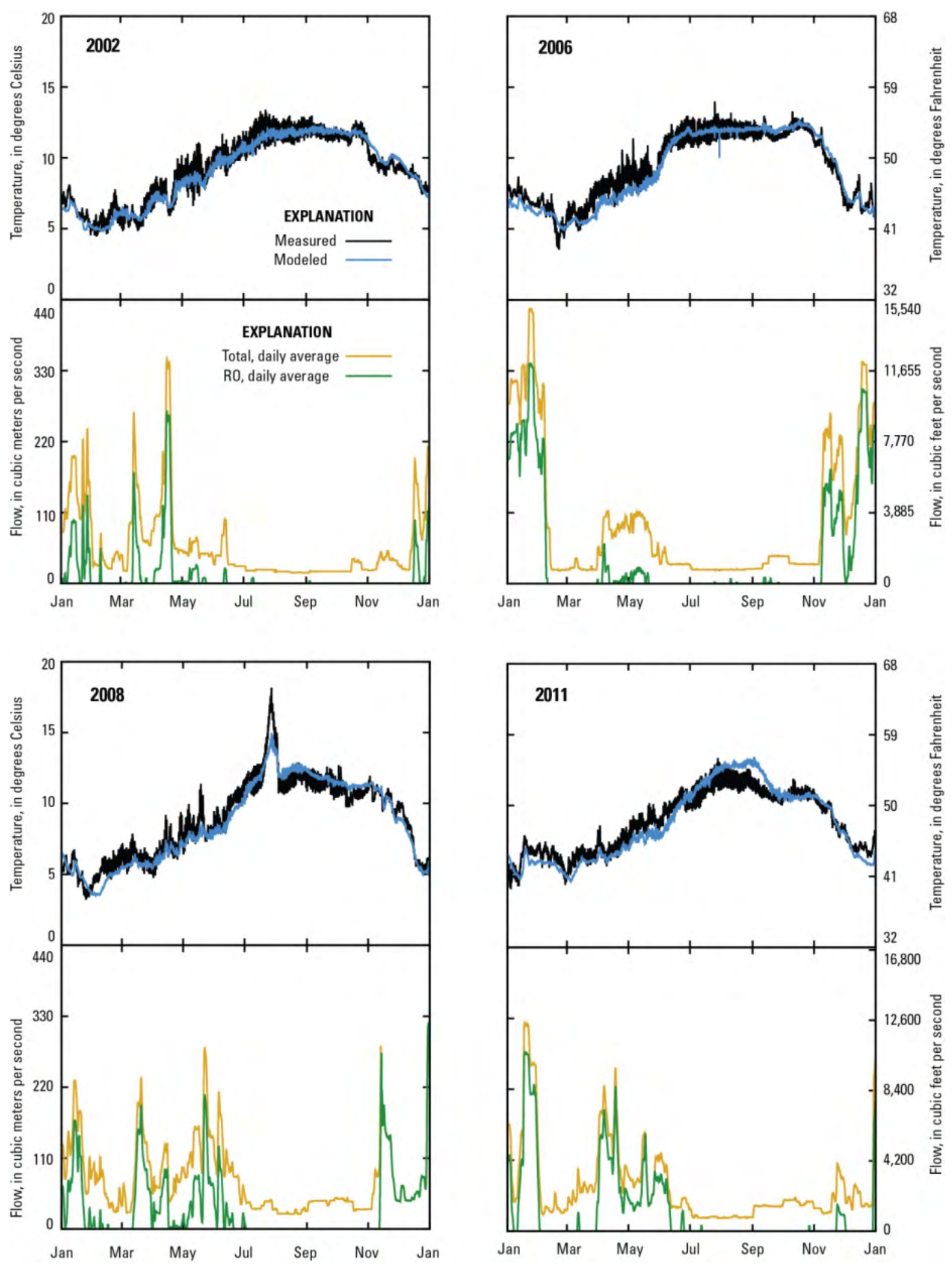

Figure 26. Graphs showing modeled outflow temperatures and measured water temperatures for Foster Lake, Oregon, downstream of Foster Dam, and daily average flow through the power and spill outlets, 2002, 2006, 2008, and 2011. 
In the years modeled, Green Peter Lake was thermally stratified from spring through autumn with cold deep water and warmer water near surface. The power penstock and RO are relatively deep in the lake. In the years modeled, and because of the fluctuating water-surface elevation, the Green Peter Dam power penstock centerline was at depths of 112-200 ft (34-61 m), although the RO centerline was at depths of 171$259 \mathrm{ft}$ (52-79 m). Owing to these depths, Green Peter Dam discharged stored cold water until late in the season when the reservoir surface was drawn down (fig. 20) and the outlets could access warmer water closer to the surface. These factors caused the maximum Green Peter Lake outflow water temperatures to occur in October or November (fig. 24), rather than during midsummer as is typical of the unimpounded streams flowing into Green Peter Lake.

Measured and modeled Green Peter Lake water temperatures showed more daily and shortterm variability near surface and less variability in the deeper areas of the reservoir (fig. 23). Measured data indicated that the largest variability occurred from 20 to $40 \mathrm{ft}$ (6 to $12 \mathrm{~m}$ ). The model showed most variability from 0.5 to $40 \mathrm{ft}(0.2$ to $12 \mathrm{~m})$. Overall, the GPR model was able to simulate water temperatures within the reservoir and its outflow well, with mean absolute errors ranging from 0.45 to $0.77^{\circ} \mathrm{C}$ (table 10).

Green Peter Lake and Foster Lake were thermally stratified from spring through autumn in the study period. Foster Lake is shallower and has withdrawal outlets closer to the water surface than Green Peter Lake. In the years modeled, the Foster Dam power penstock centerline was at water depths of 16-56 ft (5-17 m), and the spillway crest was at depths of 3-43 ft (1-13 m). Owing partly to these shallower outlet depths, the water temperatures released from Foster Dam were closer to a natural seasonal temperature pattern, with the warmest release temperatures in mid-summer (fig. 26). Other contributors to a more natural seasonal temperature pattern could include warming in the riverine reach between
Green Peter Dam and Foster Lake, and the unregulated inflow from the South Santiam River. Although the maximum water temperature of Foster Dam releases tended to occur in midsummer, temperatures throughout summer were colder than might have occurred without the upstream dams because releases from Green Peter Dam were so cool during summer (Rounds, 2010).

Calibration of the FOS model included adjustment of the wind sheltering coefficient (WSC) to 0.5 and an increase in the light extinction coefficient (EXH2O) to 0.60. Remote sensing data has suggested that Foster Lake may have occasional algae blooms (Oregon Department of Environmental Quality, 2011b) that could explain the need for greater light extinction compared to Green Peter Lake, where algal blooms have not been an issue (Oregon Department of Environmental Quality, 2011b). The Foster Dam power penstock withdrawal structure also was adjusted during calibration. It was set as a CE-QUAL-W2 "LINE" type structure with a width of $3.8 \mathrm{~m}$. In CE-QUALW2, the width of LINE structures affects which depths are able to be accessed by the outflow structure. As the model outlet line width increases, the model withdraws more water from model layers (depths) nearer the outlet. As the outlet line width decreases, it withdraws water from a greater portion of the reservoir depths. Because the model's selective withdrawal algorithm does not have a perfect representation of the three-dimensional dynamics near the outlet, the outlet width can be considered a model calibration factor (for example, Buccola and others, 2012, p. 51). The FOS model simulated water temperature well, with MAE from 0.43 to $0.72^{\circ}$ (table 10). 


\section{Implications for Future Research and Monitoring}

River and reservoir models on the Middle Fork Willamette and South Santiam River systems were constructed or evaluated, set up to simulate recent conditions with current dam operations, and calibrated so that they accurately simulated water-surface elevations, streamflow, and water temperatures in those waterbodies. Water temperatures generally were simulated with typical errors of $0.4-0.8^{\circ} \mathrm{C}$ and little to no bias when compared to measured data. These models are now ready to be used to evaluate different types of dam operations, to determine the effects of wet or dry future conditions or the effects of climate change, and to provide insights into the potential effects of using different types of outlets at these dams.

These models, while accurate and useful, demand a large quantity of certain types of data. If these models are to be updated to reflect future conditions, it will be important to continue to collect the most critical types of data needed to drive and calibrate the models, or be prepared to estimate those data. Streamflow, water temperature, and meteorological conditions are the most obvious critical inputs to the models, but verification and refinement of the model grids might be aided through periodic bathymetric surveys of the river and reservoir reaches of interest. An underwater survey of the outlets at Hills Creek Dam might improve the model calibration near the dam, as the outlets in the model were particularly hard to define in the calibration process. A field survey of tree canopy cover and topographic features or Geographic Information System processing of LiDAR along the Middle Fork Willamette River between Hills Creek Dam and Lookout Point Lake could provide additional information leading to further calibration of shading parameters in the model. Additionally, discrete or continuous vertical profiles of water temperature in each lake are invaluable for checking the calibration of these models.
Finally, the accuracy of these models is only as good as the most-critical model algorithms in those models. The flow and heat-exchange algorithms in CE-QUAL-W2 use good mathematical interpretations of the physical processes acting in those waterbodies. Potentially valuable model refinements might include a more detailed physical representation of the selective withdrawal process, in which flow from different layers of the model is directed to the structural outlets of the dams, and perhaps a quasi-threedimensional representation of circulation in areas of reservoirs where the currents are complex, such as the area where the Hills Creek arm of Hills Creek Lake joins the main branch very close to the dam.

\section{Acknowledgments}

The authors thank John Risley of the USGS Oregon Water Science Center for his assistance in completing water-temperature regressions for the South Santiam River Basin, and Steven Sobieszczyk of the USGS Oregon Water Science Center for assistance with the analysis of aerial photographs of the Middle Fork Willamette River reach between Hills Creek Dam and Lookout Point Lake.

\section{Supplemental Materials}

The models developed and refined during this study, along with the model source code and model inputs, are available for download at http://or.water.usgs.gov/proj/mfw_ssr_temp/. 


\section{References Cited}

Annear, R., Wells, S., and Berger, C., 2005, Upper Spokane River model in IdahoBoundary conditions and model setup and calibration for 2001 and 2004: Portland, Oregon, Portland State University, Department of Civil and Environmental Engineering, Technical Report EWR-2-05, 187 p.

Bartholow, J.M., Hanna, B., Saito, L., Lieberman, D., and Horn, M., 2000, Simulated limnological effects of the Shasta Lake temperature control device: Environmental Management, v. 27, no. 4, p. 105-125.

Barnes, H.H., 1967, Roughness characteristics of natural channels: U.S. Geological Survey Water-Supply Paper 1849, 213 p. (Also available at http://pubs.usgs.gov/wsp/wsp_1849/.)

Bowen, J.D., and Hieronymus, J.W., 2003, A CEQUAL-W2 model of Neuse estuary for total maximum daily load development: Journal of Water Resources Planning and Management, v. 129, no. 4, p. 283-294.

Buccola, N.L, Rounds, S.A., Sullivan, A.B., and Risley, J.C., 2012, Simulating potential structural and operational changes for Detroit Dam on the North Santiam River, Oregon, for downstream temperature management: U.S. Geological Survey Scientific Investigations Report 2012-5231, 68 p. (Also available at http://pubs.usgs.gov/sir/2012/5231/.)

Cole, T.M., and Wells, S.A., 2011, CE-QUALW2 - A two-dimensional, laterally averaged, hydrodynamic and water-quality model, version 3.7: U.S. Army Corps of Engineers, Instruction Report EL-11-1 [variously paged].

E\&S Environmental Chemistry, Inc., and South Santiam Watershed Council, 2000, South Santiam watershed assessment: E\&S Environmental Chemistry, Inc. and South Santiam Watershed Council, final report, $224 \mathrm{p}$.

Gregory, S., Ashkenas, L., and Nygaard, C., 2007, Summary report to assist development of ecosystem flow recommendations for the
Middle Fork and Coast Fork of the Willamette River, Oregon: Corvallis, Oregon State University, Institute for Water and Watersheds, 237 p.

Hanna, R.B., Saito, L., Bartholow, J.M., and Sandelin, J., 1999, Results of simulated temperature control device operations on inreservoir and discharge water temperatures using CE-QUAL-W2: Lake and Reservoir Management, v. 15, no. 2, p. 87-102.

Johnson, D., Petersen, R., Lycan, D., Sweet, J., Newhaus, M., and Schaedel, A., 1985, Atlas of Oregon lakes: Corvallis, Oregon State University Press, 319 p., updated atlas information accessed July 23, 2013, at http://aol.research.pdx.edu.

Larson, D.W., 2000, Willamette Reservoirs Oregon. Detroit, Big Cliff, Green Peter, Foster, Blue River, Cougar. Limnological and waterquality studies, 1950-2000. Final Report: U.S. Army Corps of Engineers, 1402 p.

Lawrence, M.G., 2005, The relationship between relative humidity and the dew point temperature in moist air-A simple conversion and applications: Bulletin of the American Meteorological Society, v. 86, p. 225-233.

Lee, K.K., and Risely, J.C., 2002, Estimates of ground-water recharge, base flow, and stream reach gains and losses in the Willamette River Basin, Oregon: U.S. Geological Survey WaterResources Investigations Report 2001-4215, 52 p. (Also available at http://or.water.usgs.gov/pubs_dir/WRIR014215/.)

Linsley, R.K., Jr., Kohler, M.A., and Paulhus, J.L.H., 1982, Hydrology for engineers (3d ed.): New York, McGraw-Hill, 508 p.

McElhany, P., Chilcote, M., Myers, J., and Beamesderfer, R., 2007, Viability status of Oregon salmon and steelhead populations in the Willamette and lower Columbia Basins: Prepared for Oregon Department of Fish and Wildlife and National Marine Fisheries Service, Northwest Fisheries Science Center, Seattle, Washington. 
Middle Fork Willamette Watershed Council, 2012, Middle Fork Willamette Watershed : accessed July 22, 2013, at http://www.mfwwc.org/middlefork.html.

National Marine Fisheries Service, 2008, Willamette Basin Biological OpinionEndangered Species Act Section 7(a)(2) Consultation: National Oceanic and Atmospheric Administration Fisheries Log Number F/NWR/2000/02117 [variously paged], accessed July 29, 2013, at http://www.nwr.noaa.gov/hydropower/willamet te_opinion/index.html.

National Oceanic and Atmospheric Administration, 1998, Automated Surface Observing System (ASOS) User's Guide: accessed July 22, 2013, at http://www.nws.noaa.gov/asos/pdfs/aumtoc.pdf.

Oregon Department of Environmental Quality, 2011a, Laboratory Analytical Storage and Retrieval (LASAR): Portland, Oregon Department of Environmental Quality Web application (database), accessed July 22, 2013, at http://deq12.deq.state.or.us/lasar2/.

Oregon Department of Environmental Quality, 2011b, Oregon DEQ harmful algae bloom (HAB) strategy, Appendix C: Portland, Oregon Department of Environmental Quality, 101 p., accessed July 23, 2013, at http://www.deq.state.or.us/wq/algae/docs/Appe ndixC.pdf.

Oregon Department of Fish and Wildlife and the National Marine Fisheries Service Northwest Region, 2011, Upper Willamette River conservation and recovery plan for Chinook salmon and steelhead, FINAL-August 5, 2011: Oregon Department of Fish and Wildlife and the National Marine Fisheries Service Northwest Region, 462 p., accessed, July 23, 2013, at http://www.nmfs.noaa.gov/pr/pdfs/recovery/chi nook_steelhead_upperwillametteriver.pdf.

R Development Core Team, 2009, R-A language and environment for statistical computing: Vienna, Austria, R Foundation for Statistical Computing, ISBN 3-900051-07-0, accessed July 23, 2013, at http://www.Rproject.org.

Rounds, S.A., 2007, Temperature effects of point sources, riparian shading, and dam operations on the Willamette River, Oregon: U.S. Geological Survey Scientific Investigations Report 2007-5185, 34 p. (Also available at http://pubs.usgs.gov/sir/2007/5185.)

Rounds, S.A., 2010, Thermal effects of dams in the Willamette River Basin, Oregon: U.S. Geological Survey Scientific Investigations Report 2010-5153, 64 p. (Also available at http://pubs.usgs.gov/sir/2010/5153/.)

Sullivan, A.B., Rounds, S.A., Deas, M.L., Asbill, J.R., Wellman, R.E., Stewart, M.A., Johnston, M.W., and Sogutlugil, I.E., 2011, Modeling hydrodynamics, water temperature, and water quality in the Klamath River upstream of Keno Dam, Oregon, 2006-09: U.S. Geological Survey Scientific Investigations Report 20115105, 70 p. (Also available at http://pubs.usgs.gov/sir/2011/5105/.)

University of Oregon, 2012, Solar Radiation Monitoring Laboratory data source: Eugene, University of Oregon Web site, accessed July 23, 2013, at http://solardat.uoregon.edu/.

U.S. Army Corps of Engineers, 2009, Willamette Valley projects configuration-operation plan, Phase I report, October 2009: accessed January 9, 2014, at http://nwpapps.usace.army.mil/environment/do cs/willamette/basinwide/WillametteCOPOct09_MainRpt.pdf

U.S. Army Corps of Engineers, 2012a, Data query: Web site, accessed July 23, 2013, at http://www.nwdwc.usace.army.mil/perl/dataquery.pl.

U.S. Army Corps of Engineers, 2012b, Willamette Basin annual water quality report for 2011-Final Report, April 2012: 123 p.

U.S. Environmental Protection Agency, 1997, Analysis of the effect of ASOS-derived meteorological data on refined modeling: 
EPA-454/R-97-014, accessed July 23, 2013, at http://www.epa.gov/scram001/guidance/met/as os.pdf .

U.S. Geological Survey, 2012a, StreamstatsOregon: Website, accessed July 23, 2013, at http://water.usgs.gov/osw/streamstats/oregon.h tml.

U.S. Geological Survey, 2012b, National Water Information System-Web interface: Website, accessed July 29, 2013, at http://waterdata.usgs.gov/or/nwis/sw.

West Consultants, Inc., 2004a, Development of a CE-QUAL-W2 Model for Hills Creek Reservoir: Seattle, Washington, prepared for
U.S. Army Corps of Engineers under contract DACW57-02-D-0005, 42 p.

West Consultants, Inc., 2004b, Development of a CE-QUAL-W2 Model for Lookout

Point/Dexter Reservoirs: Seattle, Washington, prepared for U.S. Army Corps of Engineers under contract DACW57-02-D-0005, 40 p..

West Consultants, Inc., 2005, Development of a CE-QUAL-W2 model for Green Peter and Foster reservoirs: Seattle, Washington, prepared for U.S. Army Corps of Engineers under contract DACW57-02-D-0005, 43 p. 


\section{Appendix A. Updated Model Parameter Sets}

This appendix details the specific changes made to the original West Consultants models of (1) Hills Creek Lake, (2) Lookout Point and Dexter Lakes, and (3) Green Peter and Foster Lakes. The differences in model parameter values between the West Consultants models and the updated Hills Creek Lake and Lookout Point and Dexter Lake models are listed in table A1. The differences in data sources for those models are listed in table A2. The differences in model parameter values between the West Consultants models and the updated USGS Green Peter and Foster Lakes models are listed in table A3.

Table A1. Differences in model parameter values between the original West Consultants models and the updated U.S. Geological Survey Hills Creek Lake and Lookout Point and Dexter Lakes models, Oregon.

[Abbreviations: ${ }^{\circ} \mathrm{C}$, degrees Celsius; HCL, Hills Creek Lake; LOP-DEX, Lookout Point and Dexter Lakes ]

\begin{tabular}{|c|c|c|c|}
\hline Parameter & West Consultants & USGS & Description \\
\hline WSC & $\begin{array}{l}0.75 \text { for HCL } \\
0.80 \text { for LOP-DEX }\end{array}$ & $\begin{array}{l}0.30 \text { for HCL } \\
1.00 \text { for LOP-DEX }\end{array}$ & Wind sheltering coefficient, dimensionless \\
\hline DYNSHD & $\begin{array}{l}0.63 \text { for HCL } \\
0.60 \text { for LOP-DEX }\end{array}$ & $\begin{array}{l}1.0 \text { for HCL } \\
1.0 \text { for LOP-DEX }\end{array}$ & Allows all incoming solar to reach the water surface \\
\hline VISC & OFF & ON & Vertical eddy viscosity limitation on timestep \\
\hline CELC & OFF & $\mathrm{ON}$ & Internal gravity wave limitation on timestep \\
\hline PQC & OFF & $\mathrm{ON}$ & Density placed inflows \\
\hline PRC & OFF & $\mathrm{ON}$ & Precipitation included \\
\hline QINIC & OFF & ON for $\mathrm{HCL}$ & Interpolate inflows \\
\hline DTRIC & OFF & ON for HCL & Interpolate distributed tributary inflows \\
\hline HDIC & OFF & ON for HCL & Interpolate boundary conditions \\
\hline METIC & OFF & ON for HCL & Meteorological data interpolation \\
\hline FRICC & MANN $(0.025)$ & CHEZY (70.0) & Bottom-friction calculation method \\
\hline $\mathrm{AX}$ & 2.0 for $\mathrm{HCL}$ & 1.0 & Longitudinal eddy viscosity, $\mathrm{m}^{2} / \mathrm{s}$ \\
\hline DX & 2.0 for $\mathrm{HCL}$ & 1.0 & Longitudinal eddy diffusivity, $\mathrm{m}^{2} / \mathrm{s}$ \\
\hline TSED & 10.0 & $\begin{array}{l}10.3 \text { for HCL } \\
10.7 \text { for LOP-DEX }\end{array}$ & Sediment temperature, ${ }^{\circ} \mathrm{C}$ \\
\hline TSEDF & 0.00 for $\mathrm{HCL}$ & 1.00 for $\mathrm{HCL}$ & Heat lost to sediments that is added back to water column \\
\hline $\mathrm{AZC}$ & W2 for HCL & $\mathrm{W} 2 \mathrm{~N}$ for $\mathrm{HCL}$ & Form of vertical turbulence closure algorithm \\
\hline AZMAX & 0.5 for $\mathrm{HCL}$ & 0.005 for $\mathrm{HCL}$ & Maximum value for vertical eddy viscosity, $\mathrm{m}^{2} / \mathrm{s}$ \\
\hline QOT & Daily for HCL & Hourly & Branch Outflows \\
\hline QDT & Not Used & $\begin{array}{l}\text { Estimated to close } \\
\text { water balance }\end{array}$ & Distributed tributaries \\
\hline TDT & Not Used & $\begin{array}{l}10 \text { percent surface } \\
\text { water, } 90 \text { percent } \\
\text { groundwater }\end{array}$ & Distributed tributary temperature \\
\hline EXH20 & 0.45 for LOP-DEX & 0.20 for LOP-DEX & Extinction coefficient for pure water \\
\hline
\end{tabular}


Table A2. Differences between meteorological data sources in the original West Consultants models and the updated U.S. Geological Survey Hills Creek Lake and Lookout Point and Dexter Lakes models, Oregon.

[Abbreviations: HCL, Hills Creek Lake; HCWO, Hills Creek Dam Weather Station; LOP, Lookout Point Lake; DEX, Dexter Lake; LPWO, Lookout Point Dam Weather Station; NCDC, National Climatic Data Center; EUG, Eugene airport weather station; USACE, U.S. Army Corps of Engineers; SRML, Solar Radiation Monitoring Laboratory].

\begin{tabular}{|c|c|c|c|c|}
\hline Parameter & Model & West Consultants & USGS & Description \\
\hline \multirow{2}{*}{ TAIR } & HCL & $\begin{array}{l}\text { NCDC EUG regression, } \\
\text { Agrimet HCKO }\end{array}$ & $\begin{array}{l}\text { NCDC EUG regression } \\
(2002), \text { USACE HCWO }\end{array}$ & \multirow{2}{*}{ Air temperature } \\
\hline & LOP-DEX & $\begin{array}{l}\text { NCDC EUG regression, } \\
\text { Agrimet LKPO }\end{array}$ & $\begin{array}{l}\text { NCDC EUG regression } \\
(2002), \text { USACE LPWO }\end{array}$ & \\
\hline \multirow{2}{*}{ TDEW } & HCL & $\begin{array}{l}\text { NCDC EUG regression, } \\
\text { Agrimet HCKO }\end{array}$ & $\begin{array}{l}\text { NCDC EUG regression } \\
(2002), \text { USACE HCWO }\end{array}$ & \multirow{2}{*}{ Dew point temperature } \\
\hline & LOP-DEX & $\begin{array}{l}\text { NCDC EUG regression, } \\
\text { Agrimet LKPO }\end{array}$ & $\begin{array}{l}\text { NCDC EUG regression } \\
(2002), \text { USACE LPWO }\end{array}$ & \\
\hline \multirow{2}{*}{$\begin{array}{l}\text { WIND, } \\
\text { PHI }\end{array}$} & & \multirow{2}{*}{ NCDC EUG } & \multirow{2}{*}{ NCDC EUG } & \multirow{2}{*}{ Wind speed, wind direction } \\
\hline & LOP-DEX & & & \\
\hline \multirow{3}{*}{ CLOUD } & HCL & \multirow{3}{*}{ unknown } & \multirow{3}{*}{ NCDC EUG } & \multirow{3}{*}{ Cloud cover } \\
\hline & & & & \\
\hline & $L U P-D E \Lambda$ & & & \\
\hline \multirow[b]{2}{*}{ SRO } & HCL & PRIMET $^{2}$, Agrimet HCKO & \multirow[b]{2}{*}{ SRML EUG } & \multirow[b]{2}{*}{ Solar radiation } \\
\hline & LOP-DEX & PRIMET $^{2}$, Agrimet LKPO & & \\
\hline
\end{tabular}

${ }^{1}$ In 2002, NCDC EUG data from 2006, 2008, 2009, and 2011 were used to estimate USACE LPWO and HCWO.

${ }^{2}$ Solar radiation data was multiplied by 2 . 
Table A3. Differences in model parameter values between the original West Consultants models and the updated U.S. Geological Survey Green Peter Lake and Foster Lake models, Oregon

[Abbreviations: Airp, Airport; ${ }^{\circ} \mathrm{C}$, degrees Celsius; $\left(\mathrm{W} / \mathrm{m}^{2}\right) / \mathrm{s}$, watt per square meter per second; GPR, Green Peter Lake; FOS, Foster Lake; spill, spillway; power, power penstock outlet; EUG, Eugene airport weather station; SRML, Solar Radiation Monitoring Laboratory]

\begin{tabular}{|c|c|c|c|}
\hline Parameter & West Consultants & USGS & Description \\
\hline WSC & $\begin{array}{l}1.00 \text { for GPR } \\
0.70 \text { for FOS }\end{array}$ & $\begin{array}{l}1.00 \text { for GPR } \\
0.50 \text { for FOS }\end{array}$ & Wind sheltering coefficient, dimensionless \\
\hline DYNSHD & 0.90 & 1.00 & Allows all incoming solar to reach the water surface \\
\hline VISC & OFF & $\mathrm{ON}$ & Vertical eddy viscosity limitation on timestep \\
\hline CELC & OFF & $\mathrm{ON}$ & Internal gravity wave limitation on timestep \\
\hline PQC & OFF & ON & Density placed inflows \\
\hline $\mathrm{EVC}$ & OFF & $\mathrm{ON}$ & Evaporation included in water budget \\
\hline $\mathrm{PRC}$ & OFF & ON & Precipitation included \\
\hline QINIC & OFF & $\mathrm{ON}$ & Interpolate inflows \\
\hline DTRIC & OFF & $\mathrm{ON}$ & Interpolate distributed tributary inflows \\
\hline HDIC & OFF & ON & Interpolate boundary conditions \\
\hline METIC & OFF & ON & Meteorological data interpolation \\
\hline CBHE & 7E-08 & 0.3 & Coefficient of bottom heat exchange, $\left(\mathrm{W} / \mathrm{m}^{2}\right) / \mathrm{s}$ \\
\hline TSED & $\begin{array}{l}7.00 \text { for GPR } \\
9.0 \text { for FOS }\end{array}$ & 11.1 & Sediment temperature, ${ }^{\circ} \mathrm{C}$ \\
\hline TSEDF & 0.00 & 1.00 & Heat lost to sediments that is added back to water column \\
\hline STR SINK & $\begin{array}{l}\text { FOS spill: LINE } \\
\text { FOS power: POINT }\end{array}$ & $\begin{array}{l}\text { FOS spill: POINT } \\
\text { FOS power: LINE }\end{array}$ & Outlet structure types \\
\hline STR WIDT & FOS power $=5.8$ & FOS power $=3.8$ & Outlet structure width \\
\hline EXH2O & FOS: 0.45 & FOS: 0.60 & Light extinction coefficient for water, $\mathrm{m}^{-1}$ \\
\hline TDT & $\begin{array}{l}100 \text { percent surface } \\
\text { water }\end{array}$ & $\begin{array}{l}80 \text { percent surface } \\
\text { water, } 20 \text { percent } \\
\text { groundwater }\end{array}$ & Distributed tributary temperature \\
\hline Met source & $\begin{array}{l}\text { TAIR: EUG, FOS } \\
\text { DEWT: EUG } \\
\text { WIND: EUG } \\
\text { PHI: FOS } \\
\text { SRO: Primet } \\
\text { CLOUD: zero }\end{array}$ & $\begin{array}{l}\text { TAIR, DEWT: FOS } \\
\text { WIND, CLOUD: EUG } \\
\text { SRO: SRML }\end{array}$ & Source of meteorological data \\
\hline
\end{tabular}




\section{营}

品

ळิ亠

年

z.

产

वृ

$\frac{\widehat{\Phi}}{\mathrm{O}}$

올

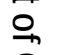

!़̣

단

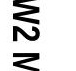

음

웅

$\stackrel{\bar{\sigma}}{\vec{D}}$

ISSN 2331-1258 (online)

http://dx.doi.org/10.3133/ofr20131186 